University of Rhode Island

DigitalCommons@URI

Open Access Master's Theses

1981

\title{
A Review and Evaluation of the State of Rhode Island Coastal Resources Management Program
}

Lee R. Whitaker

University of Rhode Island

Follow this and additional works at: https://digitalcommons.uri.edu/theses

\section{Recommended Citation}

Whitaker, Lee R., "A Review and Evaluation of the State of Rhode Island Coastal Resources Management Program" (1981). Open Access Master's Theses. Paper 722.

https://digitalcommons.uri.edu/theses/722

This Thesis is brought to you for free and open access by DigitalCommons@URI. It has been accepted for inclusion in Open Access Master's Theses by an authorized administrator of DigitalCommons@URI. For more information, please contact digitalcommons-group@uri.edu. 
A REVIEW AND EVALUATION OF THE

STATE OF RHODE ISLAND

COASTAL RESOURCES MANAGEMENT PROGRAM

BY

LEE R. WHITAKER

A RESEARCH PROJECT SUBMITTED IN

PARTIAL FULFILLMENT OF THE REQUIREMENTS

FOR THE DEGREE OF MASTER OF COMMUNITY PLANNING

UNIVERSITY OF RHODE ISLAND

1981 


\title{
MASTER OF COMMUNITY PLANIING
}

\section{RESEARCE PROJECT}

OI

\author{
LEE R. WEIIAKER
}

APPROVED:

Unfor Professor:

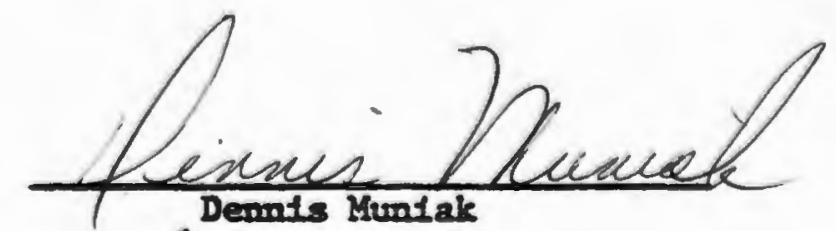

Director:

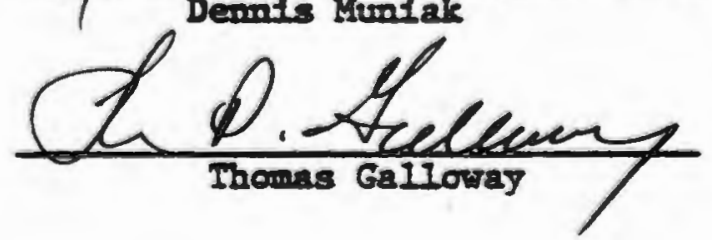


ABSTRACT

The Rhode Island Coastal Resources Management Program is entering tts second decade. Created by the Rhode Island General Assembly on 1971, the Coastal Resources Management Counctl adopted in 19.77 a management program thit was approved by the Federal Office of Coastal Zone Management in May," 1978. The state has beer receiving \$1 million annually in federal atd, matched by nearly a quarter of a million dollars in state funds, to Implement 1ts Coastal Management Program.

The Bhode Island Program has been Intensely examined during the past nine years by federal evaluators, environmental groups, and inhouse program consultamts. These evaluatfons have directed sharp crit1cism toward the Council and its management program. Program administrators: and the Councti have succegsfully deflected criticism and have argued that the Program has had a beneficlal effect on the state's coastal reglon.

Ints research project traces the historical context of the Rhode Island Coastal Resources Management Program and analyzes, through Its case load, its deciston-making environment and its management program. The mafor program weaknesses are revealed as: (I) a program that has not developed a management plan that is sultably tallored to the diverse resource base: (2) a progran that has not developed and adopted developwent standards and decision-making criterla tallored to fit permissible uses; and (3) a program that retains a large amount of Council discreHor in the dectston-making process, which, if unchecked (by a fatlure 
to remedy the first two weaknesses), will continually delfver to Rhode Islanders a costly and difficult-to-administer program whose only conslatency is its Inconsiatency with its ow management document. 
Bout Ia seth Chit

(The cock is bound to emerge as the tide subsides.)

- ChInese Proverb 


\section{ACKNOWLEDGEMENTS}

I wish to express my thanks to the faculty and admintstrative staff of the Uatversity of Rhode Island for their efforts and cooperaHox throughout in elght gears of graduate study, and particularly durIng the preparation of this report.

I ain grataful to Dr. Demis Muntak, IIy major professor, for his endurance and skfIIful gutdance on the graduate program and thesis Ifquirements, and to Dr. Thomns Galloway, Program Director, who served on the revier panel for thls work. Thetr Ifgorous crlterla are umparalleled. Honks go also to Dr. Blad Mahayat, wow Planning Program Chatrman at the Dntversity of Iowe, who encouraged me to study planning at its most sophtstcated levels.

Yore than a thank you or an expression of gratteude $1 \mathrm{~s}$ due to Mr. Dantel F. Varta. Chief of the Bhode Island Office of State Plaming. who encourages all to practice plaming with the highest professional atandards. Bls example bas been Irvaluable over the past alght jears, and he also served on the review board for this project, offering his personal insight into the 1ssies.

Inte project would have been lmpossible to successfully complete Wthout the cooperat1on and coststance of Ur. Irank P. Geremta, Ass1stant Director of Operations at the Bhode Island Department of Environmatal Management. And a thank jou of unqualified proportlons is offered to Hs. Curol Clotola tho skillfully typed the drafts and flalshed mamuseript. 
No measure of appreclation is large enough to reflect the value of the patience and support of my wlfe, Linda Rose, and our daughter, Alexandra.

Lee E. Whitaker

Untversity of Rhode Island

Yay, 1981 
TABLE OF CONTENTS

PAGE

Abstract ......................................................... 1

Acknowledgements............................................ $11 \pm$

Table of Contents................................... v

Llst of Acronyus.......................................vili

List of Tables.............................................. 1x

Introducton: Profect Descrlptlon, Purpose and Pormat......... I

Chapter One: Development of the Pederal Coastal Zone KanageLct and the Federal Requirements for Coastal Hhragement Programs............................ 7

A. The Stratton Commission: Framework for Coastal Zone Management......................

B. The Coastal Zone Management Act of 1972: RenIftes of Implementation................. 10

I. A weter of Control................... 10

2. The Shffting. Fedaral Target Syadrome..... 14

Chapter Two: Devefopment Brolution of the Rhode Island Cosstal Resources Mansgement Program.............. 23

A. Sumary of Early State Efforts.............. 23

B. The Governor's Cominttee or the Coastal Zone, 1969: A State Focus................. 24

C. The Expanded Comnittee, 1970: The Shtft to the LocaI Focus.................................. 30

D. The Frogran Prospectus: 1 Gulde for the Gruedal Firse Step.................................

E. Conten Resources Mnargement: The Shakedown Perlod..................................... 
Chapter Three: The Dec1s1on-Mak1ng Process of the Rhode Island Coastal Resources Managewent Program ......................................

4. Process Descrlption......................... 44

B. Permft Processing...................... 54

C. Letters of No objection.................. 63

D. Cense and Des1st Orders................... 65

8. Publte Beartngs............................ 76

F. Cruc Project Dentals........................ 79

G. Conclustons on RICRMP Inplementat1 on

Beaed ox Caseload Analysis................ 98

I. "Lands1de" Implementation: Program Impect......................... 98

2. Programmatic Deviation and Inconsistencles: Three Eramples:

a. Central Barrler Beach: Geographic Ares of Particular Concerm.......... 101

4. Couservation/Low Intensity Uae Coestal Wacers........................ 106

c. Coast Guard Barrler Beach: GeoGraphtc Area of Particular Concern.

3. Areas for Preservation and Restoration: Case Study of the Pettaguamscutt Rtver, Programattc Patlure...................

E. Beflectlone on the IRDC Report on the Bhode Ialand Cosntal Progran, 1976

I." Aseasament of the Effect of OCWS as a Polley Souree on Program Development and Implemententor.

J. Intermal Perception of the GRMC's Mssion: 1972 V. $198 I$ 
Chapter Four: Findings and Recomendations................ 167

A. Jurtsdiction and Control........................... 167

B. OveraII Management Procedures.......................... I72

C. Organtzat1on...................................... 185

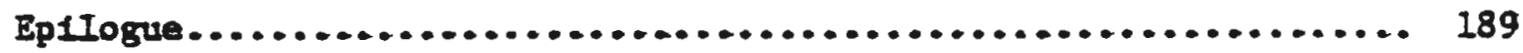

B1bl1ography........................................... 193

Appendir I: Rhode Island Coastal Resources Management Developnant Standards....................................... I-I

Appendtx II: Tabulated Profeet Data by Communtty, Naterbody and Erofect Iype.......................................... II-I 


\section{ACRONYMS}

C \& D's: - Cease and Desist Orders 1ssued by the Rhode Island Coastal Besources Management Counc1l.

CBMC - Bhode IsIand Coastal Resources Management Council.

CaMA - Federal Coastal Zone Management Act of 1972, as amended.

DEA - Dhode Island State Department of Envlrommental Management.

DCR - Division of Coastal Resources in the Rhode Island State Department of Environmental Management.

DOC - Dnted States Department of Commarce.

ear. - Dafted States Goverment Accounting office.

ISDS - Individual Sewage DIsposal System.

Lro's - Letters of No ObJect1on Issued by the Rhode IsIand Coastal Besources Management Counc1l.

NEPA - Mational Enviromental Polfey Act.

HOA - Hational Oceanic and Atmospheric Admintstration, Uatted States Department of Commerce, parent of the Office of Coastal zone Management.

IIRA - Karror Rfver Preservation Assoctation, Ine.

IBDC - Datural Resourceo Defense CounctI,..Ine.

oczat - Bederal Offlce of Coastal Zone Management, Admfoistering Agency of the Federal Coastal Zone Management Act.

RICRRP - State of Rhode Island Coastal Resources Management Program.

SEDU - Stogle-PandIY Dwelling Onft. 
I. I980 GaMC NorkIoads: Applicatlons Reviewed Results of Moving to two Meetings per Month.....

2. Time Perfods for Case Processing.

3. Inventory of Letters of No ObjectIon, July, $1979-$

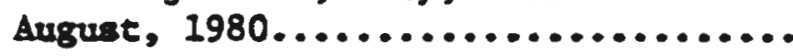

4. Inventory of Cense and Desist Orders/Orders to Remove and Restore, January, 1980 ingust. 1980 .

5. AppIfeations Reauleing from Cease and Dealst Orders, December, 1979 - Oetober, $1980 \ldots . . . .$.

6. Eublic Eearings on AppIfcations from December, 1979, -

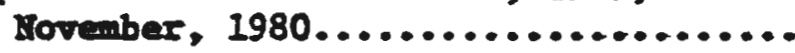

T. Major Cases Out to PubIle Hearing During Sample Perlod, December, 1979 - November, $1980 . . .$.

8. Categorlzation of alI Cases out to Publlc Bearing During Sample Perlod, December, 1979. -

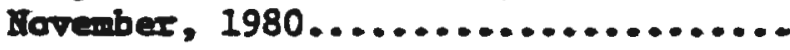

9. Bntmeted Coets for a Publfe Bearlng.......................

10. GRer Profect Dentals.......................................

11. Partial Llst of Aseents for Structures in Barrington River Since $1979 . \ldots \ldots \ldots . . . \ldots \ldots \ldots . . . . . . . .$.

I2. Projects on Barrler Beaches Before the Gac for Full 30-Day Not1ce, December, 1979, to Apr11, 1981

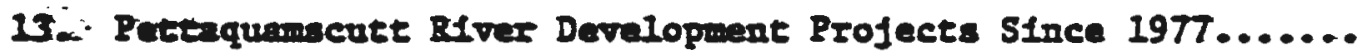

14. I972 Cuae atth Infor Comane/Objection from Stateridde RLanntag Progran.......................

15. 1977 Casen with Mnfor Blologleal and/or Englneerlng Comnene/Objectlon..........................

16. Summary of Isawas Rataed at Begtiming of CRMC's Woricshop, IacuIty Center, URI, Hovember 29, 1972. 
II-1. Projects Before CRMC by CoastaI Waterbody............

II-2. Tabulated Bfndings for Project Locstlons...............

II-3. Cmec AppIfcation by Projeet Type and Communtey, rovember, 1979 - December, 1980 .

II-4. CRic AppIfcations by Project Type and Waterbody, November. 1979 - December, I980. 


\section{INTRODUCTION}

The Officlal news organ of the Planning profession recently reported that regulatory efficlency has become a high-prlortty item durIng the past three years for some planning agencles as they have been worklng to; roduce more efficlent methods of protecting the environment while still acsommodating growth. ${ }^{1}$ Thts is not a surprising developmant followis the decade of enacting enviromental legislation at the state and patlonal leveI. Business in formulating comprehenstve environmental Iegislatior vas espectally brisk in the early 70 's with the birth of IIPA and a wide range of state and federal enactments from Bawaif's Iand Doe law to the antlonal Coastal Zone Management Act of 1972 . Iftele new activity in thls realm has occurred since the 1975 fallure of Congress to ensct national land use legtolation. 2

Bhode IsIand was. In step wht, if not ahead, of the pack in 1971, whew the state's Gencral Assembly enacted the CoastaI Resources Management Act a year before Congress launched the National Coastal Zone Management Program. Comprebensive land management legislation was similarly developing at the state and patfoual levels when the process colIapsed in the Onfted States Congress. The atmosphere at the Rhode Island state level searly sustained the impetua for land management in 1976 , but the nomentur bas Iagsed in subsequent General Assembly sessions.

In aplte of the change in the tonor of the times, Interest in CoastaI Zone Management. Iematns strong at the state and natlonal levels. ${ }^{3}$ -. The federal program and the state programs it spawned are closely 
watched and thetr efforts regularly gauged by a host of monttors from GAO to profess1onal environmentalists.

Ir keeping with the spirlt of professionals who engage in monftorIng and evaluation of programs to create more efficlent regulatory processes and to measure their effectiveness, thls report examines the Rhode Island Coastal Resources Management Program's (RICMMP) ef 'ect1veness. It does this by examining the course charted by state and federal legisIatfre mandates and utflizes a program review and evaluation approach that compares that course wth the progress of the state's program as it Is acturily implemented.

The flrat questlon, Indeed the paramount quest1on, is, "Does the program result in beneftes to soctety?" The answer to this question shall be obtatned by measurlng the program's operatlonal results against goals and objectfves. These operational measurements will be evaluated to determine the program's overall afflctency in deIfverlag the intended reaulte and to determine if there are untented impacts. The real world consequences of the program are, therefore, the subfect matter bere; and they will be evaluated in terms of products and the costs incurred. If the program is determined to be Iess effective and less efficlent than would be desirable, the programmatc theory and the process roots of these shortcomings will be revealed." Iranelated Into everyday language, the quastor beconas, "What difference does the Rhode Ialand Cosseal Resources Ymagenent Program (RICuYP) make in the CoastaI Beglon?"

Thte report begtes with ar explanation of the historical context of federal and atate coastal zone mmagement and the resultant management 
programs or program process criterla that evolved at those governmental levels. This context is crucial because it reveals the forces that shaped the present state program. The analysis then proceeds through the RICRMP document to discern the adopted dectslon-making criterla and the process devised to adbere these crlterla to proposals for development in the state's Coastal Reglor. The third step follows with the eviluation of the case-loat typology and the results of the management proceigs. The report concludes whth a section of findings and recommendations, fneluding optlons for changes to the Leglslat10n, the RICRMP, and the mongement process.

This format is consistent with what Theodore Polster bas Iabeled a a growlig tendancy to Ifnk studieg of program process with program impacts in the "feed-back loop" of monttoring and evaluation." Such a feed-back Ioop has been absent from the Bhode Island Program for the atne years of Its exlstence. Some small attempts at measuring the program's lmputs and outputs were made during the preparation of the State of Rhode Island Cogatal Regources Manggement Program, 6 and more recent efforts have been comprtsed of two annual federal eveluations as mondated by Section 312 (CZMA) and a state revlew of procedure by an "outslde consultant" hired with the U.S. Buvlromental Protection Agency and Federal office of Coastal zone Management funds. ${ }^{7}$ The most significant evaluation was prepared by a consortim of emviromental groups in I976 as a coment on the Inte1n Menagemant Program submttted to the Offlee of Contal zooe Mmageneat for federal approval. " That ovaluation foumd gIaring defletenctes in the Kanngement Program and recommended mafor changes. Bhode Island then requitred another two years to create a 
management program. No evaluation has been 1nternally generated by state program personnel, however, and this report is an effort to lnithate the feed-back loop and supply the Program with the necessary data base and evaluation. 9

No attempt is made to evaluate the Rhode Island Coastal Management Program with respect to sectlons of the Bederal Coastal Zone Management Act other than Section 306. Dectalons made Fis-a-vis other sectlons of the Act must be in conformmce with the Section 306 Management Program and are bandled through the management process established thereta. 
1. Amertcan Planning Assoclation, "Research Digest," Planaing, Vol. 46, No. 9, (September, 1980), p. 24.

2. DanteI R. Mandelker, "Symposium: Lav and PIamolng in the EnvironmentaI Decade," Jounal of the Amertcan Planning Assoctation, VoI. 46, Io- 2, (AprII, 1980), p. 133.

3. Although the Reagan Administration bas targeted the Coastal Management Program for total federal phase-out whin the next flscal year, this budget issue will be declded within the context of the revolutlonary budgetary approach currently espoused in Washington, D.C.

4. Theodore H: Polster, Publfc Program Analysis: Applfed Research Methods. (BaItfmore: Unt7ers1try of Park Press, 1978), pp. 9-11, 55, and 56.

5. Ibld-. PP. 8-9.

6. State of Rhode Is Iand Coastal Resources Managenent Program: March 14, 1978, (Provldence, Rhode Island: Rhode Island Coastal Resources Management Counc11, 1978), Pp. 1- 1 .

7. Malcoln I. Grant, "Procedural Evaluation of the Rhode Island Coastal Resources Management Program: Recommended Improvements," (Hope Valley, Rhode Island: Resources Management Sygtems, Inc., February, 1980).

Office of Cosstal Zone Management, Braluation of the Rhode Island Coantal Management Program for the Grant Period from Jamuary I. 1979. to December 31, 1979. (Washington, D.C.: Office of CoesEat zoee Nemagement, Jume 6, 1980).

Office of Coastal Zome Management, Section 312 Findings, Evaluation of the Bhode Island Cosstal Management Program covering the Grant Perfod May, 1978, - February, 1979, (Washington, D.C.: Office of Coaseal Zone Management, Apr11 19, 1979).

8. Richard Brooks and Renneth Payne, et. al., "Presentat1on of Audubon Soclety of Rhode Island; the Matural Resources Defense Counc1l, Inc.: Bcology Action for thode Island, Inc.; Conservation Lax

Toundatton of Rhode InInd; Amertean ifttoral Soctety. Ine.," Be-

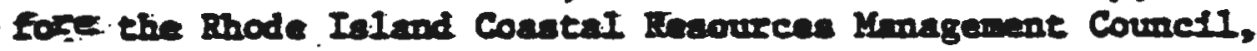
InIF 26. I976, Stente Bouse, Bhode InIand.

9. There Is an Iten in the Bhode Istand Fork Program for F 1980-81 for the Untreralty of phode Island, Cosetal Resources Center (CRC) to cooduct a program revten and prepare regulation refinements. The Cre affort bae resulted in modifications to the RICRMP which are the flrat to the Progran since 1ta adoption. The CRC's effort is 
drawing upon the same data base as this project; and, in fact, there is some considerable material drawn from this work and supplied to the CRC. However, the CRC effort is not akin to a monltorling and evaluation process, nor will it establish a feedback loop. In fact, the need for on-going internalized data generating monftoring and evaluatfon system is highifghted by the GRC's effort which wrst rely on Marfoe Resources Speclalists wth Ittele or no bands-on-experfence with the RICRMP and who are totaily dependent upon operations personnel for Information and data. 


\begin{abstract}
$\Delta 11$ the higher, wore penetrating ideals are revolutionary. They present themselves far less in the gutse of effects of past exper1ence than In that of probable causes of future expertence, factors to which the environment and the lessons it has so far taught us must leare to bend.
\end{abstract}

- Willtam James 
CEAPTER ONE: DEVELOPMENT OF THE FEDERAL COASTAL ZONE MANAGEMENT ACT AND THE FEDERAL REQUIREMIENTS FOR COASTAI MANAGEMENT PROGRAMS .

A. The Stratton Commission: Framework for Coastal Zone Management.

The national effort to devise a mechanism for better management of martne resources was offictally launched in June, 1966, with the enactment of Public Law $89-454$ which established the Comintssion on Marline Scfence, Rngfneering, and Resources. Rnown as the Stratton Commisston, after its Chatrman, Dr. JuIfus Stratton of the Ford Foundation, the 15-member Investigative team, was charged "to examine the aation's stake in the development, utilization, and preservation of our marine environment... formulate a comprehensive, Iong-term natfonal program for martne affalrs, (and)...recommend a plan of goverment organtzation to implement the Program."I

Tro years of effort by that Commission resulted in Our Nation and the Sea, a report which significantly noted the uniqueness and importance of the coastal zone for trade, industry, and blological productivity and whtch found the complexity of managing activities Ir this zone to have "outrum the abilfties of the local governments who alone had the responstbllitfes for plaming and developing resolufow to these problems. ${ }^{2}$ In testimong glven before the House Merchant Marlne and Fishertes Conference on Coastal Zone Management, in October of 1969, Dr. John A. Knauss, Provost for Marine Affairs, 
University of Rhode Island, and a prominent member of the Stratton Commission, emphasized the increasingly competitive nature of the uses of the Coastal Region resulting from population increases and shifts, soctetal affluence, and scale and types of activities rangtng from recreation to energy production. 3

Doctor Knauss emphasized a major conclusion of the Commission: -.." "Effective management (of the coastal zone) to date has been thwarted by the vartety of government furtsdictions fnvolved at all levels of goverment, the Iow prtorfty afforded to marlne matters by state goverment, the diffusion of responstbility among State agencles, and the fatIure of state agenctes to develop and implement long-range plans." 4 To cope with this problem, Bnauss reported that the Commission arrtved at a second major conclusion: "that the management task was primartly a state responstbility and that the federal government should encourage the state to accept this responsibility."5 These statements are cructal to understanding the problems of Cosstal Zone Management because thes point to the tsave of furfsdiction. That is, who will have the authorlty over what.

The Commission Fiewed the state role as cructal "to surmount speclar Iocal interests, to assist local agencles in solving common problens, and to effect' strong Interstate cooperation. "6 To accouplish Its misefor in the coastal zone, the state would require "sufficlent planofne and regulatory authorfty." Kanss confirmed that the Commission had not developed a prescription that each coastal state had to follow. ObvfousIy. the spectal sets of circumstances within each state would 
help to shape the management mechanism. It could be either a singlestate authority or volunteer commission. In fact, the Commission reaItzed the federal government could, at best, only serve up inducements for states to particlpate in such a scheme. $T$

Regardless of the speciflc shape of a particular state's management mechantsm, the Comnlssion belleved its effectiveness would hinge on four speciffc powers. These were reported by Knauss to the House Conference as (I) Plaming, (2) Regulation, (3) Acquisition and Entnent Domatn, and (4) Development. These powers would enable the state to prepare comprehensive plans for coastal waters and theis adjacent lands; manage through zoning, easements; Ifcenses and permtts and whatever other controls would be required to ensure development in conformance with the plan, including outright acquisition, if required, and development of such public factifties as beaches and marinas, and leastog lands and offshore lands. 8 These findings and recommendations were to serongly Influence the early efforts in Thode Island.

A year after the Strattor Commission Report, a second rationally prominent pubItcation was released by the O.S. Department of the Interfor under the title of The National Estuary Study. Mandated by the Estuary Protect1on Act, Public Law 90-454, the report conveyed a picture of on-going destruction of the nation's estuary system, with the findteng that:"

Betuarles are in feopardy. They are being damaged, destroyed, and reduced in size at an accelerating rate by physical alteration and by pollation. They are favorlte places for industry, which finds the land cheap, water transportat1or easy, and waste dis- 
posal convenient. They are also favorite places for residential developers who find it exceedingly profitable to dredge and fill an estuary and thus destroy part of it in order to appeal to affluent Amertcans to Iive near the water in houses whtch are accessible by boat and automobile.

Following on the heels of these major reports was a sertes of Ieglslative inftiativesat the Congressional Level to enact a National Coastal Zone Management Program.

B. The Coastal Zone Management Act of 1972- Real1t1es of Implementation.

I. Mateer of Coatrol.

Ir response to the Stratton Commission report, Senator Warreq G. Magnuson Introduced in August, 1969, legislatton (S 2802) to create a Coastal Zonè Management Program for the qation. Magnuson's Iegislatton was followed by a plethora of Coastal Management proposals in the House of Representatives and the Senate. 10 In all proposals, the deftartion of the area to be managed efther posed or reflected problems wth the landward line of demarcation, while there seemed to be little problem In estabIlshing the furthest extent of the seaward boundary at the "Iandward extent of martitime Influences." 11 other Iegislation defined it as "not to exceed 20 inles inland where martitme influences exerctse direct effect on the Iand "II Another defintelon was "that in close proxdmtty and strongly influenced by the coastine." I3 Efforts to enact coastal management legislatfor continued into 1971 when legtslation was foEroduced by Senator Ernest F. Hollings (S 582) and by Senator John 
Tower (S 638). Their legislation defined the inland boundary as the extent that the land was "influenced by the water."14

Definition of the boundary not withstanding, all pleces of Iegtolatfon, following the recommendations of the Stratton Commisstor, placed the management burden on the states with the flextbilit. to evolve their individual management programs. The day followIng the Eollings inttlative with S 582, Senator Robert L. Byrd, Introduced S 992 to create a land management mechanism for the nation, recognizing the coastal zone and estuaries as areas of critucal envtromental concers. I5 As the legtslation began to be reshaped, the coastal legtslation's inland boundary needs changed. A flexdble water-orlented definition appeared in S 3507: "Shorelands whose we had a direct and slgniftcant impact on the coastal water." The House companion to S 3507 , H.R. I4146, stated the taland boundary was to include "only those shoreland areas the control of which is necessary to the effective management of the coastal water themseIves." I7 Both pieces were leaving the landside to be covered by the land management leglalation. Responsibility for administering the coastal program was assigned to the Nattonal Oceantc and Atmosphertc Administration in the U.S. Department of Commerce as recommended by the Stratton Commisston. The Conference Committee Report on S 3507 and H.R. 14146 defined the inland boundary of the coastal zone to be "those lands whtch have a direct and slgmificant impact upon the coastal water. "18. This legtslation passed and was stgned Into law on October 27, 1972, as Public Law 92-583, more than one year after the state of Rhode Island had enacted coastal management Iegislation. 
The issues of authorfties and the inland boundary are the two keys to understanding the problems of managing the activities of the Coastal Region. The Stratton Commission recomendations emphasized strong authorttles to be fmplemented at the state levelauthorlties so strong that the zoning mechantsm was envisioned among other powerful tools, and whlle the CZMA did not uttlize that term, It clearly required a landward orfentation of a kind necessary to manage activities that have a direct and significant impact upon coastal waters. However, the Act is not spectfle in this regard, and relegated definitions and standards to the administrative rulemalfig process. It is clear that at the state level, implementaton of concepts such as these could sum aground stiff local opposition. Unless, of course, the necessary groundwork could be enplaced through public involvement/education, and a role was reserved for Iocal governments whose furfsdiction was most strenuous1y threatened by strong state programs.

The May, 1975, Coastal Zone Management Workshop at Asilomar, Calfforala, was devoted to the theme "From Plaming to Practice," and there was a heavy emphasis on public particlpation. 19 Speaikers in the session Included Donald Strauss of the Amertcan Arbitration Assoclation; Dr. Ntels Rorbolm,. Professor of School Oceanography, Onfverstty of Rhode Island; and the Bonorable Burt Muhly, Mayor of Santa Cruz, Calfforata. Thetr message was clear. Local governmats bave succumbed to development pressures and have wrecked the coastline. The general citizenry are not fovolved in the decisionming process. Local goverment control results in fragmented 
governance of the region. The majortty of people are being manipulated by local governments while people who do particlpate in goal-setting and declsion-making do so to attain specific ends. People do not trust the data provided by experts. Public partictpation In Coastal Zone Management is a necessary long-term process that is required to bring the public into contact with decisionmaking.

Mulf produced a Iengthy sIfde pregentation visually documentIng the deterforation of the aesthetfe and recreatlonal values of the Calfforata Cosstal Regtor; the shoreline in particular, as a result of purely local dectslon-making. Munley's findings echo those expressed elsewhere by the early ploneers in coastal zone management. At the ThIId Annual New England Coastal Resources Management Conference in Durham, New Hamphire, 1n November, 1972, South KIngstown, Rhode Island, Town Counc1Iman Walter Gray was reported to have placed heavy responslbility on local polfticlans for the woes of constal resources. Local officlals, he sald, are "prone to proclaim their deep affection for our great natural resources and them bend Itke spaghett when thelf votes stack us against some vested Interest." 20 It is local officlals who disparage and undermine the concept of statewlde and reglonal coastal management and pleming, and It to these locel pollefclans who will continue to ilfor hophezard coastal development whout restr1ct1on. 21 However, nafther MuhIeY's fIndings, nor Gray's acknowledgements, nor the atrength of the Strattor Commtssion report taken separately or 
together could sustain the efforts to create strong state programs. The CZMA places many burdens upon state programs to factor in diverse Interests, and Iocal governments have too much at stake to allow substantial state control over activitles and uses within their polftlcal boundaries. This has had predictable results at the national and state levels.

2. The Shifting Federal Target Syndrome.

It wes dfficult enough for states to have to contend with the jealous prerogatives of local governments, but the plight of State Coastal Program Managers was exacerbated by the federal "carrot and stick."

Edward T. LaRoe, former Chlef of the Florlda Bureau of Coastal Zone Management and a former OCZM staff person, and Elizabeth Shelry Roy have advanced documentation that the Federal office of Coastal Zone Management has been inconsistent in 1ts admintstration of the CaMA because it (OCZM) lacks explictt pollcles and standards-a feature compounded by the polfcy to keep flextble to allow individual states to develop programs sutted to each state's unique polftical and cultural climate. The result of this form of administration has been the creation of a welter of state programs with varying enphasts on alde range of targets. LaRoe and Boy state: "the reviev and approval of state programs has continued to be conducted on an ad hoc basts and has frequentIy been based upon the opinion of or Interpretation by the reglonal coordinators." 22 They add that 
this lack. of crlteria has been felt at the state level by complicating the task of program managers trying to develop programs acceptable to their constituencies. 23

This charactertstic of the federal end of the Coastal Zone Management Program has persisted through program development into program evaluation. The four princtpal oCzM criteria for program evaluation have been: (1) protection of significant natural resources; (2) more effective management of coastal development; (3) Increasing access to the coast; and (4) Increasing intergovernmental cooperattor and coordination. 24 LaRoe and Roy make the points that these criterla are new; are not derived properly from the hortatory language of the CAMA, Sectlons 302 and 303; are not standardized; and regardless of how lauditory these criterla may be, they are symptomatic of continutag inconsistency which, when vfewed collectively, show "that ocam has applied inconsistent criterfa based upon frequently nonexdstent objectives." 25 Not surprisingly, there has been a drive nationally by the Coast Alliance, the CoastaI States Organization, and others, to tighten up at the federal level because of the delays, disputes, and total fatlure of state programs resulting fiom the ever-shifting federal target. This constant federal motion has severely affected the development and Implementation of the Rhode Island Program.

The Inly 22, 1975, OCay stte v1s1t at Newport, Rhode Island, 27 approxtmately one year after the state recelved its first Sectlon 305 ptanofing grant, 11lustrates the problems that resulted. State 
coastal officials were instructed by Messers Robert Knecht, OCZA, Director, and Richard Gardiner, leading OCZM staff person, that five ftems were necessary for state program approval. First, the state was required to define 1ts coastal zone; and to satisfy this requirement, the state could elther put a line on a map or include the whole state; presumabiy the latter option was a result of the peculfar jurisdictional authorfties of the Rhode Island Coastal Resources Act and the state's smallness.

Regardlese of the definftion of the zone, Knecht matncained that the requirement. was "an operational definttion," and coordination betweer regulatory agencles had to be spelled out. Thls became known as Ilnkage or "networking" or as one wit at an Afrlie, VIrginta, CZM Workshop described 1t, "Rnechtions." It was emphasized that the state had to have adequate control over land and water uses. Second, the state had to define the geographic areas of concerr that were whit the control of the state management program- Infrd, the state program was required to designate what prtortty of uses would be adopted in the Rhode Island Coastal Tone- Thts requirement was deffned with an emphasis on permisstble uses for the geographic areas of particular concern. The requirement was that permissible uses need only be defined rather than Isted. StIII. Gerdiner believed this to be the core to a coestal management prograw. The fourth and fifth necessary features of an approvable management program were assurances that local goverments could not restrict uses of a "regtonal benefit" and 
that the state program could not restrict uses of a "national benefit."

Wherr Rhode Island first received approval in March, 1974, for Its program development grant, and became one of the first three recipients nationwide, it was commonly aclonowledged that the state would receive approval of its management program within two years because Rhode Island had an excellent history in Coastal Zone Management, notably the 1971 Coastal Resources Management Act. So, at the concluston of the JuIy 22, 1975, site Vistt, euphorla relgned among State Coastal Resources Management CoumefI members. They had beex Informed by OCAM's legal counsel that the Rhode IsIand IegisIation was among the best. All that remained, it seemed, was docuwentation of the five conditions.

The Office of Coastal Zone Management was caught nationally between the polftical reallties of wore than 30 cosstal states and tercftortes, tts statutory mandate, and tts administrative gufdeInes: and regalations. In a well-intentloned effort to assist the stated to prepare management programs, by perhaps attempting to comb through the grey areas created by the merging of local polftical realities and federal requirements, OCZi released, in early 1976, a set of seven "Threshold Papers." 29

These pupers contatined what OCAM belleved to be the minimal acceptable standards that the states needed to meet for 306 approval. They were based on the regulations, but there were instances "by ocar admission" where the regulations and the Threshold Papers were 
not totally compatible. ${ }^{30}$ Some states welcomed the attempt by oCZM to "elucidate" the minimum standards, but found them, in some cases, "to be confusing," and lacking in flexibility. Other states found them to provide excellent guidance. 32 while for some states, the papers merely raised as many questions as they attempted to answer. 33

Enough confusion arose from the Threshold Papers to necessttate a New England and Mid-Atlant1c States Program DIrectors meeting on January 23, 1976, at the World Trade Center. That meetfins touched upor the varlous ways states were trying to cope with plectog together a program. New York saw the networking of extstfng regulatory programs on a reallstic approach that recognized that "bold new legislation is impossible." 34 Dick Gardner of OCZM gaw real approval problems coming in those states with little or. no environmental leglslation. He stated that sooner or later OCZM would be confronted with the half-a-1oaf versus the whole-loaf probIem. 35

Sara Chasts of the Natural Resources Defense Council, writing critfcaIIy of the Coastal Management Act's progress through 1979, sustatned the crfticlsm of LaRoe and Roy. It is her conviction that "atnce commencement of the federal program, OCZM has continued to ater and revise the requirements for 306 (Mamagement Program Grant) approval." ${ }^{36}$ Stre attacked this feature of OCZM's admintstrative style as fafling to insure protection of valuable coastal resources because "they place heavy emphas1s or procedure rather than substance." 37 
Based on this, one would perhaps not be surprised to learn that Rhode Island's Program approval did not occur until May 12, 1978, nearly three years after the Newport site visit. As $1 t$ turned out, a fourth year of plaming was allowed by amendment to the CaMA and later a fifth year to assist reluctant states as all experienced grave difficulties in defining boundaries, authortties, uses, geographic areas, uses of regional benefit and uses of nathonal interest. In 1976, Rnecht at Alrlie, Virginia, related the "history" of the discovery of the Planet Pluto as analogous to the development of approvable coastal programs. Astronomers, he stated, bypothesized the planet's existence and had worked out the mathematical proofs prfor to its actual sighting by telescope. So too. OCMM hypothes1zed, there were approvable state CZM programs (other than Washington State, which had received approval in 1975) out there wafting to be discovered. Based on what has followed, one wonders if Rhode Island's coastal telescope has been properly focused. 
1. The Ifbrary of Congress, Congressional Research Service, Leg1slative History of the Coastal Zone Management Act of 1972, as amended In 1974 and 1976, (Washington, DC: U.S. Government Printing Office: 1976), P. 10 .

2. Ib1d., p. 2 .

3. Ib1d., pp. 13, 14 .

4. Ib1d., P. 14 .

5. IbId.- PP. 14, 15.

6. Ibtd-. p. 16.

7. Ibid-. P. 15 .

8. Ib1d., P. 16 .

9. IbId-, p. 3.

10. IbId., p. 4.

1I. IbId.

12. IbId.

13. Ibfd-

14. IbId-, P. 5 .

15.- IbId- - . 6 .

16. Ib1d-, P. 7 .

IT. IbId.

18. Ibtd.

19. Lea R. Whttaker, Personal Notes, CaM Workshop, Astlomar, Califorala, un 27-30, 1975.

20. The Providence Evening Bulletin, "Local Offlctals Scored on Shoreland Palictes," November I, 1972.

2I. Ibta. 
22. Edward T. LaRoe, and Elizabeth Sheiry Roy, "Federal Inconsistency: Administration of the CZMA in the Absence of Explicit Federal Policies and Standards," Resource Allocation Issues in the Coastal Environment, proceedings of the Coastal Society Fifth Annual Conference, (Arlington, Virginia: November 6-8, 1978), p. 1 .

23. Ib1d. This problem was espectally acute to Rhode Island's Case wher the state submitted a management program in Jume, 1976, expecting approval because it had been prepared in hand-inglove fashion with OCZM personnel, but only to be badly received by that office because of a critical analysis of th? state's program by NRDC and others, setting the stage for t.jo additional years of program preparation.

24. IbId-, P. IT.

25. IbId., P. 2I.

26. Ibtd., p. 23. The 1980 Amendments to the CZMA appear to make an attempt at correcting this problem, but it is too soon to declare this attempt as effective or as a success.

27. Lee R. Whitaker, Personal Notes, Federal Offlce of the Coastal Zone Management Site V1sit, Newport, Rhode Island, July 22, 1975.

28. These directions from OCZM were consistent with the statutory requirements of Publfc Law 92-583, the Coastal Zone Management Act of 1972, Section 305.(a) and the Admintstrative regulations, 1.e., CFR Paxt 920.11 through 920.15 in Federal Reg1ster Vo1. 42, No. 83. April 29, 1977, Pp. 22042-22044.

29. OffIce of Coastal Zone Menagement, "Threshold Paper No. 1: Boundartes:" "Itrreshold Paper No. 3: Geographle Areas;" "Threshold Paper No. 4: Public and Governmental Involvement;" Threshold Paper No- 5: State-Federal Interaction and Natfonal Interests;" and "Ihreshold Paper Nos. 6 and 7: Organization and Authortites."

30. Dantel H. Varlm, Rhode Island Stacewlde Planning Program, Memorandum or OCaM Threshold Paper for 306 Program Approval, January 12, 1976.

31. Allen Pease, Director, State Plaming Offlce, State of Mafne, Letter to Jown Sun, Northeast Beglonal Coordinator, U.S. DOC, MOAA, . OCAY, February 5, 1976.

32. Reginald W. Woolard, CoestaI Resources Management Profect Director, Ite Hampshire, Letter to Mr. John Sur, January 20, 1976.

33. Charles E. Evans, Bnv1rommental Analyst, Connectlcut Department of Enviromental Protection, Letter to Mr. John Sun, February 2, 1976; 
and Dave Berle, State of New York, Department of State, Memorandum to Hank Williams, on Federal CZM Threshold Papers, January 22, 1976.

34. Lee R. Whitaker, Personal Notes, New England Mid-Atlant1c Program Managers. Meeting, January 23, 1976.

35. Ibid.

36. Sara Crasis, "The Coastal Zone Management Act," Journal of the Amercan Planning Association, Volume 46, No. 2 (April, 1980), P. 151.

37. Ibid.

22 
He who ftghts the future has a dangerous eneur - The future is not, it borrows its strength from the man himself, and when It has tricked him out of this, then it appears outslde of him as the enemy he wust meet.

- Soren Kierkegaard 
CHAPTER TWO: DEVELOPMERTAL EVOLUTION OF THE RHODE ISTAND COASTAL RESOURCES MaNAGEMENT PROGRAM.

\section{A. Summary of Barly State Efforts.}

The flrst signtficant study of the Rhode Island Coastal Reg1on, The Rhode Island Shore, A Reglonal Gulde Plan Study, 1955-1970, was prepared by the Bhode Island Development Counctl in 1956. The Developwent CounctI, the precursor of the present-day state Department of Beononste DeveIopment, was prompted by the damage cansed by Eurrfcane Carol in 1954, and the report was an effort to determine the mensures necessary to whofmize damage from future storms. The study was enIarged with the atd of matching state and federal funds provided under Section 701 of the Housing Act of 1954. Reflecting the emphasis of Sectson 701 on Comprehensive Communtty Planning, the report recognized the need for comprehensive master plan for planning, development and regulatory conterols concerning the Rhode IsIand shore reglon, and recommended the coordination of state, Iocal and federal agencles and private interest groups" efforts to achteve such a plan. I

The State's General Assembly reacted to the need for shoreline protection from storm damage with the "Shore Development Act of 1956 " which declared atute polles to protect and prowote the health, safety and weifare of the people, and the state's intention to assist munfelpalities in arresting, protecting, and preserving beach areas from eroston and damage by the Iements. The Lct assigned responsibility to 
the Department of Natural Resources, DIV1sion of Barbors and Rfvers, which is now the Division of Coastal Resources in the Department of Rav1rommental Management. 2

In January, 1969, the Natural Resources Group, a private ctetzen Interest group, pubIlshed the Report on Adminlstration of Narragansett Bay. The group emphastzed the historlc importance of Narragansett Bay to the development of Rhode Island and stressed the Bay's contInuIng role as the state's "greatest natural resource substantlally supporting industial, commerctal, mifleary, recreational and domestic activities." ${ }^{\text {3 }}$ The report 1dentfled tro distinct, but closely-related probleme coscerning Narragansett Bay: (I) the lack of exclsting state or IocaI goverment management policles and goaIs relative to the Bay; and (2) the lack of tnformation necessary to develop goals and pollcles. 4 These needs were not wilke those Identified in the 1956 Reglonal Guide Plan Study of the Development CounctI. The NaturaI Resources Group recommended Immediate action be taken to find the best methods for determinting and formulating Bay pollctes and the means of fuplementing and admintstering thew. 5

B. The Governor's Comittee on the Coastal Zone, 1969: A State Focus.

As a result of the Natural Resources Group's effort, and the growIng arareness of the cfilzency to the proven blstorfeal need of a comprehensive conseal sesource management program, Governor Frank Ifcht apolnted a techntcal compltee in March. 1969, as the flFst atep toward drafting future management polleles for Narraganset Bay and the entire Cosatal Region. The Technfcal Committee was comprised of afne membera representing efght state agencfes and the Untversity of 
Rhode Island Graduate School of Oceanography, ${ }^{6}$ and tes product is a model of rational-comprehenstve planning and decislon-making.

The tnitial report of the Techalcal Comntttee to the Governor was presented in March, 1970. It recommended:

(I) The State of Phode IsIand make a declarat1on regarding the Importance of 1ts coastal zone and the fntention of the state to provlde the proper planntng and management of this resowees:

(2) The management mechanism be a cosstal zone counc1l created by the General AssembIy;

(3) The Intversity of Rhode Island be deslgnated as the state's coastal zone laboratory, with primary research responsibiliLes;

(4) The Cosatal zone Councll immediately begin to prepare a comprehenstive plax for the coastal zone;

(5) Ine Councif Identify and, If necessary, InItlate the action meeded to clartfy the state's Iegal jurisdiction in the coastal zone;

(6) The Counctl review seatutes relating to the coastal zone and recounand neceseary changes:

$\because \cdots$

(T) The CounctI review exating programs and profects relating to the coastal zone and make recommendations concerning theis difrecton; 
(8) The Counc1l develop and waintain an inventory of coastal resources; and

(9) The General Assembly amend Section 42-1-1 of the General Iaws of 1956, as amended, regardtog the state's seaward boundary, so as to extend the state's furlsdiction to the maximm extent possible under existing statutes, treaties, and conventions. T

These recomendations gres out of the Comnttee's effort to define the Technical paraneters of cosstal zone management and fit the resultant definftion into an administractve framework for implementation. But, not only was there a need for forentory data on cosstal activities, there was, cruclally, the need to define the space within which these activitles, when occuring, would be a masagement concern. 9 The committee settled on a three-tier space definttion for management operathous: (I) a prtwary area, whtch roughly corresponds to the coestal dratrage basid Inter used for bastr studlea under the Clean Water Act, Sectlor 303e, and which eventually became the coastal plaming area deptcted as the RICRMP, "PrLorltles for Use in the Coastal Reglon," (2) Activity deflned space which ig the area or site of an activity impacting on the Constal Region and coastal water but Iflng Inland of the werer, poselbly inland of the primary area, and posetbIy iflng beyond the atate's bowdars, and (3) a direct regulatory zone defined as (a) alI InIand Hdal weter bodies, the territorial sea and contlguous seas subfect to state Jurladictlor, (b) the adfolntng land areas and focluded wher bodfes to a mestmum elevation of 20 feet above mean high water,

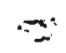


or to a maximum distance of 200 feet from mean high water, whichever provided the furtherest inland control, and (c) all islands, except Aquidneck, Conantcut, Prudence, and Block Island. 10 These were treated as "matnland."

By formulating the nine recommendations, the Committee clearly sought to create a management mechantsm that would balance the uses of the coastal zone wth the basic natural enviromment through planned development, which was envisioned as being comprehensive and long range. II ImportantIy. the gutding polfcies for the management of the zone were "to preserve, protect, develop, and, where possible, to restore the resources of the state's coastal zone for this and succeeding generations," and "preservation and restoration of ecological systems and bistorlc and aesthetic resources shall be the primary gusding princlpals upon which enviromental alterations.... w11 be measured, judged, and regulated."12 Ints Innguage was retatned in the Rhode Island Coastal Resources Management Act of 1971 . 13

The administrative body flrst recommended by the Coumbtee to impIement the Coastal Resources Act was an eleven-member gubernatorlaIlyappotnted counctI headed by an Executive Director, appointed by the Committee. Staff support would come from the classifled civil service and housed in the Department of Natural Resources (now the Department of Buffromental (magement), while the Untversity of Bhode IsIand would provide techaleal resenreh capability. The pIan (Recommendation 4) was sean as the central portion of the whole scheme. To implement it, the Implementation authoritles needed to be secure (Recommendations 5, 6 - and 9). and there bad to be certatnty that there would be cohesive ac- 
tion on the part of many actors rather than a disparate conglomeration of bodies workIng at cross purposes (Recommendations 6 and 7). The foundation of the plan was to be constructed out of RecommendaElons 3 and 8.

The plan's dependence on and centrality to the management process is reflected by the implementation guldeline requiring the Counc11 to bave the autbortty to "recommend allocatlons of land, submerged Iand, water areas, and related atr space, to spectfled actirlties or tipes of development, together with regulations designed to control these actirities...elther directy or through delegation to other govermental agencles." 14 Powerfut tools were proposed to implement the plan: (I) authortty to suspend or defer any proposed development or use of land, submerged Iand, water area and related alr space for not more than three years after the creation of the Counc1I; (2) author1ty to establish Ifcense fees or other charges for the use of state lands, submerged Iands, and water uses: (3) authorlty to acquire land, subwerged Iand or water areas; (4) authorlty to establ1sh plerhead and bulkhead Ines for shorelines; and (5) authortty to develop and operate faefIttes of ressels. 15 The Counctl was recommended as the lead state agency for coordination of coastalfy-related activitles, and it was to be Elnanced through approprlations from the General Assembly. 16

Tho proposed eleven-member mmagement Counctl had a decldedly state govermental orfentation. There vere to be four ex officlo members: Ihe directors of the state Departments of Natural Resources, Bealth. Commintty Affatrs, and the Development Coumcti. Seven public 
members were proposed representing conservation, recreation, wlldife or aesthetfc concerns (2); commerclal fishing, business, industry or tourlsm (2); education or research (1); and local goverment (2). Additlooal advisory-only nembers were recoumended. 17

Not surprisingly, the Techntcal Comntttee was guided in 1 ts efforts by keeplng a close watch on the development of coastal zone leglslation in the U.S. Congress. At that time, the model plece of leglslation was the "Yingansor BtII" which celled for comprehensive planning and developwint of the Coastal zone, to be developed in concert with Iocal authorfeles, setefog forth golls and plaming principals, and supported by distinct standards (emphasls added) to measure dectsions by and to avert arbitrary and caprletous management. 18 The Magnuson B111 called for authorfty to prepare zoning and land-use regulatlons to control development and to assure compliance with the Master Plan against which all proposals for development would be fudged subfect to full opportunity for haringe and fudtetal revier is

Leglalation based on the Governor's Techntcal Comitte recommendat1ons, and reflecting the approach modeled by the Magnuson B1II. was submitted to the 1970 session of the Rhode Island General AssembIy, but was not reported out of Commttee and died upon sesston adfourment. Kajor pleces of legtalation, wch as this, not infrequently fall passage the first tim around, espectalI, when It seeks to make broad chroges is powrs retatforshtpe. The inland boundary of the coastal zone was the princtpal stumbling block in 1970, and the powers of acquisition a anfor contributing factor, as the Iocal govermments of 21 communteles, 
or slightly more than half of the local goverments in the state, representing two-thirds of the state's populat1on, balked at the legislation's attempt to claim state control over the strip of land 200 feet Inland from mean high water or to elevatlor 20 feet, whlchever was greater. 20

C. The Expanded Comittee, 1970: The Shift to the Local Focus.

On November 23, 1970, Governor Ifcht, by Execut17e Order No. 19, reconatituted and expanded the Technical Commlttee and charged it to contsue the study of the Cosstal Region and "to propose an acceptable, effective and equttable mechantsm to ensure the proper and orderly developwent and management of Narragansete Bay and the Coastal Zone."12 The expanded comittee had greatly tocreased representation compared to the previous version, with an additional 52 members ${ }^{22}$ and seven adFisory personnel from Regtonal and Pederal Agencles added to the origlnat nto. 23

The new commttee, ackoniedging the difficulties the earlier legLeIstion had Fis-a-Vis Iocal authorttles, prepared a management program model that would have broad furtsdictlon over tidal water areas deflned as extending from mean high water to the Ifmtt of the state's territor1al ses, and Ifmited powers over land restrlcted to a few specific uses mo types of activities. 24 the planning and implementation themes remined rubetantialy intact, as did the following declsion-maktng crItents (1.e., standards): (I) capactey of areas to support activites and inpect of activitles on ecological systems; (2) state water quality semdards: (3) need and demand for sctivities and uses; and (4) compat1bitfty of actifities and uses. 25 To implement the plan, the counctl 
would continue to have the authorfty to formulate the regulations, as previously envisioned, and a 'burden of proof' requirement for developers was advanced requiring them "...to show that theif proposals would not make any ares unsultable for the uses or activities to which It Is allocated by the Coastal Zone PIan." 26

There was an emphasis before the new Committee that the modificatlons necessary to overcome local obfectlon had several major disadrantages, partleulariy with regard to the total lack of abilfty of the proposed Counctl to have an Impact or Iocal zonting and taring policles; 1te Inted role in resolving conflicts resulting from competition for Inot; an over-all Inabiltty of the Counc1l to deal with numerous spectfle problems; and a probable result that the Counctl would not be elIgtble for federal funds, should they become avatlable, because of insuffictent zoning and land acquisition powers. 27 The last point was acknowledg as bedog debatable; ${ }^{28}$ and as it turned out, it is the only prediction of the four which did not bear out.

- The Iegtalation born from the second technfeal comnttee resulted In an enactment by the 1971 session of the General Assembly, creating in Chapter 46-23 of the General Lave, as amended, a management mechanism consisting of a Coastal Resources Management Counc1l and staff. The Counctl we created with close tles to the Department of Natural Recources, as orfinaliy proposed, wth the DIflaton of Coastal Resources formad from the old Diflaton of Bnrbors and Rivers to serve as the atafe acm to the Counctl. That Diflaton had historically been the permitting agency for actioftles in and over atate coastal waters, but it acver had the broad powers for Coastal Management 
The formula for Council membership, however, changed dramat1cal1y. The Councll's size was tncreased to 17 members, and the number of ex offlcio state department members was reduced to two whth the exclustor of the Directors of Commmity Affalrs and the Development Counc1I. The number of Iocal government offictala was doubled to four, and four elected offictals from the General Assembly were added, two each from the House of Representatives and the Senate. The number of pubIfc members was lncressed from five to seven, but the type of representation criterta was completely dropped.

The formita for chooting nembers to the Counctl erentes an appearance of complesty and balance. Of the 15 appointees, 7 are allocated to the Governor, I to the Speaker of the Bouse, and 2 to the It. Governor. The formula also provides that the majortty of the members are from coastal commities and provides that small communtes of less than 25,000 in population are represented. No more than 2 persons shall be fror the sme commulty, and there is inland representation. 30

The couposition of the CounclI Indlcated a clear. Vlctory for campantilem, 31 while the Iack of crtterta for types of pubIlc representathor and the expanston of the "public" representatton threw the Counc1l open to a host of speclal Interests. Under, such a scheme, the only way clear, Forward motion could be schseved would be through deft leaderahtp and pursult of consenvus on broad goals and objectives inttially, and os particular 1sous over time. It is thts need that made the plan a erteterl document. If the plan became too spectfic, ther the Iatitude of the Iockl and special intereats would be cllpped, perhapa wore than these interests would be wilifing to accept at any particular time. 
The eventual result was adoption of a management program with has developed an Interesting implementation bistory.

D. The Program Prospectus: A Gutde for the Cructal First Steps.

Ir September, 197I, the Rhode IsIand Statewlde PIanning Program Jublished the Program Prospectus for the Coastal Resources Management Conncfl "to assist and guide the newly created Coastal Resources Management Counctl and Its staff to manage the state's coastal resources to. a maner whtch will provtde the public with the optimum use(s) of... (the) bas and the Constal Region." ${ }^{32}$ It sought to lay down the procedures for pIan development, using the work of the two technical comntttees as its base. It suggested a three-phased approach: (I) concentration on spectfic problems of mafor significance and immedlate interest; (2) data acquistt1on and evaluat1on for the plan and to support dec1sionmatefng; and (3) continuting coastal resources management and planning after the preparation of the plan. 33

The etrst problem area recomended for Counc1l attentlon by the Prospectus was its permit system, which it inherited from the Divialon of Barbors and Rtvers and which was vlewed as the basic method for control of activitles under 1ts jurfsdiction. 34 The Prospectus urged formulation of permit systen operating procedures; development of standards for erafuatlor of applicatlons, and development of exiterla "to deterafne wheh appIIentions could be hondled routinely by the staff and which would require the attention of the fulI Counc1I," 35 and it urged definition of those altuations which would require heartings. 36 
The second concern recomended for Counc1l attention was a site study for a nuclear power plact. ThIs study would fnclude site selection crteria; site evaluation, site ranking, and site development recomendations, 37 but it was not to be emphasized to the exclusion of the other technical studies required for the plan. These studies were speciffcally cited by the Prospectus as: (I) population and economic activity studies; (2) bydrological studies; (3) descriptive and andytic measurements of the physical and chemical properties of the Bay and Cosstal waters; (4) ecological studies; (5) geologlcal survey; and (6) Irventory of the activities and physical uses of the coastal area. 38 Theae technteal studies were seen as vital parts of the plan preparatou and were to be fed fnto the long-range program to "monttor" all key aspects of coastal waters. There was an emphasis here on the conceptsof baseline data and water qualfty and the allocation of uses "in accordance with the ablitty of the resources of each area to support varlous activities. ${ }^{39}$ In additlon to the power plant study, spectal arese of concerr requtring Counct attention were legal furladiction, pubIfc access, affects of Iand uses on water areas, port development, promotion of martoe commerce, and overall formulation of regulactons to Implement the plar and program.

When viewed with the benefit of nearly a decade of bindsight, the reconmendations of the Prospectus (examined withtn the context of the

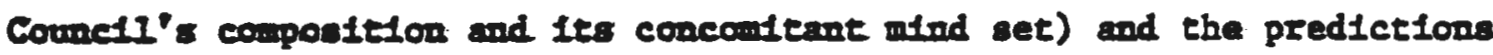
of the second technfeal comittee referred to earller, form a base for estabItshing evaluative crlterla that can be measured with objective data collected from the permftting syatem and other records matntafned by the Difiston of Coastal Resources for the Councti. 
E. Coastal Resources Kanagement: The Shakedown Perlod.

A review of the newsilie covering the first 18 months of the Gacc's extstence offers considerable Insight lnto the inftial ab1IIttes of the Council, its early concerns, and 1ts most severe probIems- It fs Important to note that The Provldence Journal and The Evening Bulletin, both Journal Company papers, endorsed the enactment of the Coastal Resources Management Act of 1971 in two editorLale in April and JuIy of that year. Once the Counctl was created In JuIF, 197I. and the appolatments made, the presoures which belped co stmulate lte crention descended upon it and, from the impresston couvgred by the prese in those early months, nearly destroyed the experiment.

Developwent on the Green Hill Barrler Beach complex in South Kingstown captured the CounctI's atention in 1972 as the town sought to Iflit development. Thls 1s8ue brought to the fore the spectre of the takfng 1soue, and underscored the need for the Comatl to have a pian. 42 Ihe Issue also brought the CounetI Into a dispute with the Department of Natural Resources conceraing enforcement of Council reguIations. 43 The tsoue is setII unresolved as the courts have ruled in favor of residental development (Anafcell1 Case) and that decision is being appealed by South KIngstown. Amlcus brlefs have been flled by the Gusc, the Unfreralty of Vermont Enviromentel Iew Sehool, OCZM and . others.

The CounctI found Itself Iocked in an interagency dispute with the State Department of Health over regulation of vessel-to-vessel transfer 
of oil. 44 The Health Department was opposed to permitting use of the Bay for such transfers, while the Council favored the activity wh proper regulation. The Councll successfully defended 1ts positor in this. case.

The CounctI also became embrotled in a proposal in the Upper Bay region to dredge and fill a 50,000 square-foot area of St1libouse Cove for the Bhode Island Yacht CIub. ${ }^{45}$ The Councll granted an assent for the project over intense local oppositfon and admitted that there was no enofrommeal impact study prepared for the profect beexuse of a complate lack of staff and money to prepare such a study. Vestiges of the Iacht CIub Iseue vere st1II plaguing the Council in exrif 1981, although the 1ssues at band were no Ionger env1ronmental or use 1ssues. Rather, the CounctI's process was belng manfpulated in an internal feud at the Yacht Club over the alfgrment of floats.

The ataffing 1ssue had been an ackowledged early problem, and it was reported that the Councll was operating wth "absolutely insuffictent" funds. 47 The Natural Resources Group recommended that the Governor appoint a fulI-tIme Executive Secretary and provlde the Dfvision of Cosstal Resources with more staff. 48 However, an unexpected problem wes generated by the first Chatrman of the Counc1l, Dr. V1acent T. Oddo. An Investgation of all the berthing fees collected at state factiftles at Galfiee, Jerunalen, and Ifverton, all operated by the Department of Datural Resources. revealed that fees were as much as 600 percent lower thn fees ebrrged at private factittes; and as a result, the state's revenues came nowhere near paylng the costs of operating and maintalning 
Its own fac1litles. 49 The difference, naturally, had to be made up from tax revenues. Out of this came reports that the lower rates were polftically motivated and that influential persons exerted pressure on state offictals to goverm the assigment of these "coveted berths." 50 Among those so charged was the flrst Chatrman of the Coastal Council. 51 This Issue has been resolved with the acceptance of subsidized berthing for the commerctal fishing Industr.

Antd the clanor over the berthing fees and alleged influence pedalIng. Ihe Providence Joural publtshed an editorlal requesting the Chatrnan"s reatgnattor from the Caxc. 52 The editorlal emphasized that the Councti had Iegtetmate problems whth lack of staff and money, but it had also caused a lack of public confidence from the "squabbling with other state agencles, and fumbled its way late Into the row over resIdenetal developments on the shore at Green Hill, and 1s stumbItng Its way through near farce in the matter of construction of a proposed East Providence chemical storage plant." 53 The editortal asked the Governor to restart the CownetI in the right direction in January. 54 Doctor Oddo Iesigned the Chatr, but be renatned on the Counctl.

The an Chatrman, formar Ifverton State Representative John A. Iyous, assumed controI of the Counc1I in 1973, and Later that year, the atate inftlated 1 s applfcation process for Section 305 CZMA planatig funds. The Council seteled lnto routhe permitelng of activities atong the ahoretine, In a fabuton afmilar to the Division of Barbors and Rivers Operations before enactment of the Coastal legtslation in 197I. Frov. Iate 1973 untII Mag, 1978, while the CounctI was engaged in "routefne" pecuttelog, its primary attention wes focused on attaloing 
federal CZMA Section 305 and 306 monies to enable the state to prepare the comprehensive management plan that was so vitally needed and then to implement It on an on-going basis as envisioned by the Sect10n 306 mandate. Ontil the exfsting plan was adopted in September, 1977, the CRAC operated on an abbrevlated set of polfcles and plan adopted in earIy 1973.55

This early flursy of "bad press" all but disappeared after 1973, but it belped to create a true "bunker mentalfty" among the old-hand Counc1l members. It also revenled to the Counctl leadershtp the beneEle of good press relations. The result has been a tendency for the CounclI to sponsor relatively noncontroverstal work, Ieaving tough issues such as aesthetics, lease fees, and highest and best use/permlgstble uses alone. It has also cost the Council its leadership role over precisely that area of the state that the Natural Resources Group In 1969 declared as the state's most Important resource-Narragansett Bay. The Governor's Office has had to resort to creating another panel to setele use conflycts on the Bay. 56 And, another spectal Commission had to be leglsiatively created to deal with the lease fee 1saue, that 18, charging users of state waters and bottom lands all approprlate fee for thetr exclusionary use, a use whtch includes filling below mean high water.

The bunker nentallty expresses tebelf most acutely whenever persow Intimatefy lovolved in or fantilne with the CaMC's Program expreso concers thet infor programmatic deviations are occurring, or that the larger Lssues are escaplng to the detrfment of the Program. The CoumcfI has apparentIy IuIIed Itself into belfeving its own press releases, 
perfodic newsletter, and laudatory praise from the OCZM Public Relatlons Spectalist. 58 The public relations approach creates an 1IILslon that provides escape from the harsh realltles revealed through the case load analya1s. For instance, it is frequentis amounced to the public through the Newsletter or television spots that the CrMC has stringent regulations on salt marshes or that the CRMC is protectIng our cosst. These statements are absolutely true, but they do nothing to convey the immense difficulty in fulfiling these objectives becanse of whe can only be descrtbed as a lack of publle acceptance of the Couc's Program. Worse, the evidence shows also that the Council itself does not fully accept or ablde by its Program. 
CEAPTER TWO: FOOTHOTES

I. The Rhode Island Development Counc1I, The Rhode Island Shore, A

Reglonal Guide PIan Study, 1955-1970, (Prov1dence: 1955).

2. General Laws of Rhode Is land, T1Ele 46, Chapter 3, Section 46.

3. Natural Resources Group, Report on Adminfstratton of Narragansett

Bay, (Provldence, Rhode Island: January 1, 1969).

4. Tbid.

5. Ibid.

6. The Ifrst Techalcal Comnttee establlshed by Governor Hicht was comprised of the heads of the Departments of Natural Resources, Health, Public Worics, Community Affatrs, the State Budget offtcer, the State Planner, the head of the Water Resources Board, a ranking Officlal from the Unfversity of Rhode Island Graduate School of Oceanography, and the Governor's Federal Coordinatox.

T. Rhode Island Statewlde Planning Program, State of Rhode Island Report of the Governor's Committee on the Coastal Zone, (Providence, - Bhode Island: March, 1970), PP. 110-112.

8. Ibid., p. 3 .

9. IoId., Pp. II-13.

10. 멈., P- 14.

II. Ibid-. P. I10.

12. Ib1d., P. 110 .

13. General Laws of Rhode Island, Title 46, Chapter 23, Sect1on 46-23-1.

14. Report of the Goternor's Committee on the Coastal Zone, p. 113.

15. Bb1d-s. PP. 113-114.

16. Ibtd- Pp. 114-115.

I7. IbId., P. IIT.

18. Ibld. $=$ g. D-3.

19. Ibta. - PQ. D-3, D-4. 
20. Rhode Island Statewide Planning Program, Program Prospectus for the Coastal Resources Management Counc1l, (Providence, Rhode Island: September, 1971), P. D-4.

21. IbId., P. A-1.

22. Three of the members of the expanded Technical Comntttee on the Coastal zone now hold key postelons in the management program. Former State Representat1ve Mr. John A- Lyons, Chatrman and pald Erecuttive Difector of the CRMC; Mr. Paul T. Hicles, pald ExecuElve Director of the Rhode Island Petroleum Assoclation, and CRMC Secretary; Mr. James T. Beattie, Former Adminlstrative A1de to Providence Mayor Joseph A Doorley, now Chief of the Division of Coastal Resources.

23. Prosram Prospectus, pp. B-1, B-4.

24. Ibld:-P. D-4.

25. Ibtd., P. D-5.

26. Ibid.

27. Ib1d.

28. Ibid.

29. General Laws of Rhode Island, IttIe 46, Chapter 23, Section 46-23-2.

30. Iotd.

3I. A term applied to underdeveloped nations expressing an underdevelopnat of econowy in tarms of a poverty of outlook, meaning ItteriIf Iojalty to orIy that which can be seen from the Campantie of ball towar, which normally would be the tallest structure in towr.

32. Program Progpectus, p. 5.

33. Ibld., P. 6 .

34. Ibld., P. 18.

35. Ibid., P. 19.

36. Ibid-

37. Ibld., pp. 19-20.

38. Inid.-PP. 20-21.

39. Ibld., p. 24. 
40. Ib1d.

41. The Providence Journal Company, The Evening Bulletin, "The Best Beglnatng," Apr11 6, 1971, and The Providence Journal,

"Save the Shore." July 5, 1971.

42. Ibld-, The Erening Bulletin, "Coastal Panel to Assume Control of Beach Growth," September 6, 1972, The Evening Bulletin, "Beach Conservation," September 1, 1972, and The Providence Journal, "Counc1I Maps PIan in 011, Beach Cases,"

43. Ib1d., The Evenlng Bullet1n, "Green B1Il Dispute Golng to Governor," September 25, 1972.

44. Tbld. The Eventng Bullet1n, "011 transfers in Bay Divide R.I. Agencles," August 28. 1972; The Providence Journal, "Council Mrpe Plan to 011, Beach Cases," September 6,1972; and The Bventor Bulletin, "Coastal Panel is Givea Primary Jurlsdictoo or Boy OLI Transfers," January 3, 1973.

45. Ibid-, The Evening Bullet1n, "Bay Guar1dan," December 27, 1972; The Prorldence Sunday Journal, "R.I. Yacht Club Project Not StudIed by Counc1I," December 31, 1972; The Brenting Bullet1n, "Tacht Club Cove Plan Draws Flre," December 28, 1972.

46. Tbld. The Provldence Sunday Journal, "R.I. Tacht Club Project Not Studled by Counc11," December 31, 1972 and R.I. Tacht Club CRMC File No. 81-1-6.

47. Ibid., The Eventag Bulletin, "New R.I. Agency Beset with 2 old ProbIems," November 9, 1972.

48. Ibtd., The Eventing Bullet1n, More Staff ts Urged for Coastal Counet." Octaber 27, 1972.

49. Ib1d.- The Provldence Sunday Journal, "State Deeply Undercuts PrIvate vardase," October 22, 1972.

50. Ibld., The Providence Sunday Jouraal, "Influence Try AIleged on Berths at Gal1lee," October 1, 1972.

51. Ib1a.

52. Ibld.. The Erening Bulletin, "Resign, Doctor Oddol" October 20, 1972.

53. IbId.

54. Ibla-

55. ConstaI Regources Management PIan, September 18, 1972, F1led wth the Bhode Inland Secretary of State, May 30, 1973.

56. Ine Providence Journal Company, The Provtdence Sunday Jourmal, "Garraby Appotnts Panel to Stady Gruups' Conflicts Over the Use of Bey." February 22, 1981. 
57. Spectal Legislattve Comission to Study and Make Recommendations Regarding Appropriate Pees to be Charged for all Private Uses of Public Waters and other Related Regulations and Statutory Provlsions, Pinal Report, (Providence, Rhode Island, Eebruary, 1981).

58. The Providence Journal Company, The Providence Journal, "R.I. Coastal Management Described as Among the Best," October 25, I979. 
I predfct a bright future for complexty. Bave you ever constdered how complicated things can get, what with one thing alwaye leading to another. 
CHAPIER THRER: THE DECISION-MARING PROCESS OF THE REODE ISIAND COASTAL RESOURCES MANAGEMENT PROGRAK.

\section{A. Process Description.}

Simply descrtbed, a person or persons acting as private cit1zens or representing any organizacton or any unt of government, must appIf for and recelve a Coastal Resources Management Counc1l "Assent" prior ta commencement of activitles withln the Councll's jurlsdiction. The application procese forolves the submiseton of plans along with \$ \$35.00 filing fee, and the project $1 \mathrm{~s}$ then put out to public notice for a 30-day revies and comment perlod.

At the end of the 30-day revlew perfod, provided that all reviews are completed and there are no objectlons, the Councli decties or the case (application). If there is an objectlon, a public hearfog is hald by a subcomittee of three Counctl members ass1sted by Iegal counsel, a court stenographer, and Diviston of Coastal Besources (Draf) staff, Including the Divlaton Chlef in every case. The bearing serves to obtaln for the Counctl "the best evidence reasonabIy obtained" 1 for and agatnst the application. When the hearing procese 1s completed, the aubcomittee flles a report with the full CounctI. vhtch then losus a dectaton that is usually consistent with the mbcouftee's Iecommendetfons and normally occurs with a month after the subcomittee report. 
Once a council decision is reached on a case, the Division of Coastal Resources staff sends an assent (or denial, whichever is the case) to the applicant. Profect modiflcations (1.e., stipulat1ons) are attached to the assent. In contested cases, the legal counseI writes the dectslor with findings of fact, conclusions of law and stfpulations, if any. Any Interested party can appeal a decision whtn 30 days after the decision is sezt to the applicant.

These are the mechantes of the process. However, to understand the process, It is essential to comprehend the apectflcs of the legtalative charge to the CRuc, and the wey that charge is programmatiexIly cransiated. The canc has direct anthortty over the entre shoreline and over those activities that are itkely to "significantly affect the shore or tidal waters." ${ }^{2}$ This authority is exercised through a direct permtteing of "all activitles between the mean high weter mark and the outward Ifmits of the state's territorfal sea, coastal wetlands, phyalographte features and ail directly assoctated arens contguous to and necensury to preserve the integrtty of such axeas and features," Ineluding coastal poods."

Thto Ianguage strongit suggests that the Counc1 has control over land use in a zone along the shore. Sectlon 120.0-2 of the RIGaP defines phyolographtcal features as being "beacbes and barrler beachea; elffes, 1edgen and bluffs; cosstal wetlands, and sand dunes." 4 The cutire shoreItne consiste of one or more of these features, except in some Instances where the land is bulkheaded in some form out paet wean 10 wher, In whtch case the Coumefl retalns authortty over the factifty and an foland zone because such man-made defices are "shoreline protection facilities." 5 
The zone in question is defined in Section 120.0-2 to be 200 feet foland from the particular physlographlcal feature. It is not programmatically defined for bulkheaded areas (unless there is a physlographical feature there also), but the Counct l has statutory authorfty over "all directly assoctated contlguous areas. which are necessary to preserve the Integrity of such facility." ${ }^{6}$ This programmatic and statutory Ianguage has created an area of dual furtsdiction where state and. Iocal authorftles converge, creating a s1tuaton where constant Iarge and sall conflicts can ensue, espectally

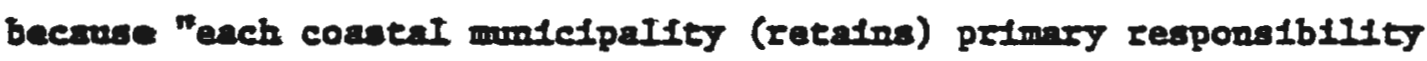
for managtng land use along 1ts coest."

The dual furfodiction is acknowledged and local authorth is acceded to in the operating pollcy that creates the Counc1I as "the last step for in-state permtt procedures (act1ng) formally on an appIfcation onfy when alI local and other state approvals have been obeatned." ${ }^{8}$ This polfoy, while conventent, has obvious Ifmitelng Features if the state acting through the Counc1I expects to exereise som form of ratlonal comprehensive and/or simply effective control In the shorevard management zone. The polley restrlcts CBMC Inltiatre and tt allows local approval and profect atart-up in ways not fully consistent with the RICRMP.

in an IIIntration of the wentended effect of this policy, records show that in 1980 . 46 percent of the applicationbefore the Counctl as a result of Cense and Desint Orders were project startupe thne had recelved Iocal butlding permits or were Iocally aponsored publfc works profects. (Cease and Desist Orders are more 
fully described in Chapter 3, Section D) There were also 51 Cease and Desist Orders 1ssued on landside projects for which local approvals were not required and/or there was either ignorance of or outright ignorlng of the atate's authortty (Table 5, Section D).

The programmatic approach to assurlng these types of deviations do not occur is wholly urrealistic when vlewed agalngt the statistics clted above. The Program requires that "Persons proposing alteraHow along the shoreline are Informed by Councll staff or by local enthorteles wher a Coumcli permit is required." "9 Damge to phys10graphical features hai often occurred by the time a.Cease and Desist Order is 1saned. As a reart, restoration, a goal of the 1971 legIslation, ts efther imposalble such as in a case of sea cliff alterattor, or impractical because of the probability of worse effects such as heavy siltation of a coastal pond as would occur when a party has: IIfegally filled and bulkheaded below mean bigh water. Moreover, these phenomens ofter occur in areas where such a project would have a ver Iow probability of befng permitted becange the evidentiary burdens of the program would be difficult or impossible to meet.

If fe the evidentary "Burdens of proof" of the Program which are simultaneousiy 1 ts strength and one of 1 ts weaknesses, at least as experlepced in present operat10ns. Statutorfly, these burdens are pIaced upon the appIfcant to demonstrate for ang development or operation withe, above or beneach the stace's tidal waters that thets proposal wII not: (I) confIlct olth any resources management pIow or program; (2) make any area unsuteable for any use or activity to whtch it is allocated by a resources management plan or program; 
or (3) significantly damage the environment of the coastal region." Authority over land areas gives the Council power which is "Iimited to sltuations in which there is a reasonable probability of confItct wth a plan or program for resources management or damage to the coastal enviromment." 11 Spectfic uses or categorles falling under the Council's landside authorfties are: power generating and desalination plants; chemical or petroleum processing, transfer, or storage; minerals extraction; sewage treatment and disposal, and 12 solid waste disposal factlities.

Programmatically, the burdens are refined to fnclude "rellable and probative evidence that the coastal resources are capable of supporting the proposed activity or alteration including the impacts and/or effects upon: clreulation and flushing patterns, sediment deposition patterns, blological communities (vegetatiox, shellfish, finftsh, Wlliffe habltat), aesthetic and/or recreatfonal value, water qualfty, public access to and along the shore, erosion and flood bazards, rumoff patterns, and exfsting activities."

These pertain to Shoreline Systems, and with the exception of the 14 exlsting activity category, Ifdal Waters, and Coastal Ponds. With regard to Itdal Waters and Coastal Ponds, the burdens are st 111 more Iforous, In that these areas are classified according to use values: conservation/Ior intenstty use, muttple use recreation, high intenatb use recreation, multiple use, and urban use. The burdens correspond to the assigned value of preservatton, and the Ianguage governIng permitted use in conservation/Iow intensity use and multiple use 
recreation areas becomes restrictive, in that certain activities will "be permitted only upon demonstration that a bona fide benefit to the public welfare will result, and, further, that no reasonable alterna15

tive exdsts." For conservation estuaries, these activities are: industrial development, sewage disposal and stormwater runoff, deposition of fill, extensive grading or excavation, installation of cables and pipelines, storage and transport of hazardous materials, dredging and structures in navigable water. In wultiple use recreation waters, these activities are simflar but less restrtcted: industrial development, dispostefor of fill, discharge of domestic, municipal and industrlal sewage, extenstve grading or excavation, storage or transport of hazardous materials, and ang activity distuptive of recreational I6

use. Permits are also required for alteration of tributary waterbodies and for the alteration of salintty and water volumes; and for proposals to fill tidal waters, applicants must demonstrate bona fide benefte to the public welfare and that there is no reasonable alternatre mans to achieve this public benelft.

Spectfic burdens have been established for applications requesting structural forms of shoreline erosion control such as rip rap or buIkheading. These profects must "demonstrate that non-gtructural wams have been fully evaluated as a solutior to the problem;" ${ }^{18}$ and, where nop-structural wethods are unsuttable, the proposed structure mot be demonstrated to have a reasonable probability of controlling exostor in the site, and not fucrease eroston on nearby areas and not have a significant adverse Impact on the areas' environmental 
quality. The use of structural erosion controls is prohibited in beach areas unless an "applicant demonstrates by probative evidence lack of available sediment" for nonstructural controls (1.e., vegetacton, fencing, sand bags, etc. Eighteen specific beach areas where this prohibition applies are listed in the RICRMP. ${ }^{19}$ Burdens are similarly established in each section of the RICRMP from Water Quality Management to commercial and industrial siting. One could easily draw the inference that each application is accompanied by evidence that these burdens have been met through evaluation by the applicant. Data collected and the lmpact analysis, theoretically at least, accompany the applicatior. However, in practice, this is not so. The most common method of addressing these burdens is to not address them at all; or, on occaston, a letter of Program conststency accomanies the application. This appears to have developed because of the seeming impracticality of requiring what is essentialIy an environmental impact statement on each project, regardless of scale and type, and it 1s fostered by the Admintstration of the Program.

Applicants are provided application forms with a checklist of up to 20 or more project description items that must accompany each application. These are not programmatically or statutorily related. Ax applicant's handbook bas been prepared and is generally 111 re-, garded by staff persomeI. It does not relate well to the RICRMP or reflect the Program's burdens on applicants. It serves mosty as a wil-intentioned vehtcle to make the RICRMP understandable to the 
greatest number of people. It is the lowest common denominator approach to public information and offers rules-of-thumb, such as "If your feet are going to get wet with salt water, you definitely need a permit," or "If you are breathing good salt air, you probably need a permit." The handbook also Ifsts informational items similar to 20 the checklist.

The product of the organizational environment described in the preceeding paragraphs is an operatton that attempts to capture through a. regulatory permitting process every form of activity within 200 feet of the inland edge of the nearest shoreline system and/or mean high water, and next to nothing further than 200 feet unless it is one of the spectfic land uses covered by the legislation. It is an operation that requires those profects captured to be subjected to an application process that requires plans and information that do not address the fundamental burdens of proof established by law and the RICRM. Thts throws the entire burden of proof onto the administerfing personnel. It Ieaves to the staff the responsibilfty of determinfing prafect consistency with the RICRMP; and whenever this determinatfor is not possible due to clear conflicts or because of subtle long-term or even supposed but uncertain conflicts, the staff triggers the burden of proof question. This does not mean that the Counctl wnIformally seeles to clartfy the 1ssues or resolve the conflicts. In fact, the staff objections to profects may not be considered objections and are not alway handled the same way as local goverment or private 21. eltizer obfections. 
Applications for Council permits are processed by the staff of the Department of Envirommental Management. "The Staff ascertains what other state and federal permits are needed and that the applicatlox procedure ts being followed in proper sequence," 22 and each profect is evaluated by a FIsh and WildIffe blologist, an engineer, the planding staff and at least one member of the CounciI. To this group, add the Chairman/Executive Director of the Counctl and the Chtef of the Diviston of Coastal Resources in the vast majortty of cases.

Data relevant to the nature of the proposal and the site are taken from the mapped data base which is or file at the Diviston of Coastal Resources. ThIs map base was prepared with CZMA Section 305 plaming montes, and tt utflizes 1975 U.S. Geological Survey base maps and ortho photos. Mylar overlays show local zoning, water and sewer service areas, signtficant natural areas, htstorle places and districts, recreation areas, flood zones, wetlands and topography at a scale of $1=12,000$ inches.

The englneer and the blologist prepare a wrltten statement which addresses the engineerfing plans submitted, site suftability assessment and recommendatlons for Councll action. This is added to the file Wth the data from the mapped data base and a polfey and regulation melysis on the proposal. Curtousits, the Counct does not requtre profeselonally prepared engloeering plans, thus, plactng total plan and afte evaluation ox the staff, and in som cases, the Councti has actually requested the staff to prepare plans for appllcants, faclud- 
23

ing developers. The Council member or members and the Division Chief who visits the site prepare no written statement for the record, but at the time of the Council's meetings, projects are introduced by these Counctl members usually acting as advocates for approval with staff, recommended modifications and/or site impact mit1gation stipulations.

AII the completed revilew forms, and a summary of the major pofnts, comments from fndividuals, groups, locaI, state, and federaI agenctes are provided to the Counctl members four to five days before they act or the applfcation. The entire package of matertals is 24

also avaliable to the public. It lacludes a report from the Rhode Island Historlcal Preservation Commission regarding the potentlal or actual historfcal and archeological resources on the project site; a Water Quality Certffication from the Divlsion of Water Resources in the Department of Envirommental Management regarding project Imacts ot water qualfty classiffcations; and a State Gufde PIan Consistency Certffeation and FIood Hazard Zone determination from the Rhode IsIand Statewfde Planning Program in the Deparcment of Admintstration. These Iatter two consistency reports are statutorfly mandated.

This procedure results in one or two volumes of materfal reproduced for the 17 Counctl members, with seven additional volumes for the staff and stenographer, and laterested parties, such as the Attorney General's Bavirommental Advocate and the Statewide PIanning Program. The photocopylng of this materfal, comblned with the reproducthon of files and transcripts for contested cases ran gearly threefourthe of a millior pages in 1980. 
Contested cases result from an objection to a proposal usually from a cltizen or a local govemment. Staff objections do produce, but not always so, a contested case, and result in public heacings, the normal outcome of an objection. The state's Admin1strative Procedures Act and the Council's own procedures "ensure ample public notice of all pending council permtt activities." Hearlngs are held if there are one or more obiections or requests far a hearing from interested partles. And, because state, federal and local agenctes and any interested citizen who so request are sunt copies of every appifcation before the Counctl, there is ample opportunfty for some party to object and kfck the project out to the Publte Hearing Process. (The effect of this is discussed in SecElon. E.)

Accoriding to the RICRMP, the expected time required to process an "uncontested applfcation" is "about 45 days." 28 contested cases take longer "with the amount of time being proportlonal to the compledty of the case." 29 . These statements while perhaps representing a valtd goal and a loglcal expectatton in both instances, are not at all reflected by the reality exhlbited by the administrative results or implementation, as it were, of the Program.

\section{B. Permite Processtog.}

In Bebruary, 1980, at the request of the staff and in response to the consulteant's procedural evaluatton, the CRMC moved to two 30

moxthly meetlngs to dectde cases. At that time, the staff's analyats of the case load revealed that the number of cases had Increased 
65 percent from 1978 to 1979 ( 153 vs. 253) and that the one meeting per month had three built-in opportunities for delay. First, because the meeting agenda is set approxdmately one week prfor to the meeting to allow for the reproduction and distribution of the files for each CRMC member to review, applications that have comment deadifnes within that one-week perlod are blocked out by the sequenc? of events and pushed off to the next meeting for a delay as much as 35 to 40 days.

A Imilar fate awatts cases that have comment deadifnes that close withix a week or two after the meeting. These can be delayed as mach as 30 to 35 days. Finally, there are applications that have commeat perlods that close prior to the setting of the agenda, but for any one of a varlety of reasons, may not have a completed file. These are ofteri uncontested cases, but for the vagaries of mail deliveries, staff case load backlogs at revienting agencles, delayed notification of the Iffting of local requests for extended review, Individual IIIress, etc., can be delayed for as much as 35 days.

By establfshing two monthly meetings, the CRMC cut these delays II half, waking a sigaiflcant difference to applicants faced with seasonal constralnts, financtal requirements, contractural possibilities, atc. Horeover. the reduced case Ioad per meeting, a volume that approxImaces that experfenced In 1978, provldes the colc greater opportunlty for deltberatton, If nacessary, on cases and affords the staff and others the opportmity to make presentations to the CRYC. It is esHmated that approxtmately I,100 days of delay were prevented between 
February 1, and October 28, 1980 , by moving to two monthly meetings (Table 1). During that perfod 43.5 percent of the decisions were reached at the second meeting, and in the last four months of the sample perfod, the second meeting actually resulted in four decisions wore than the flrst meeting.

The two meetings per month was a "quick fix" tactic deployed by the staff and accepted by the CRMC. Prfor to January, 1980, the month that the staff proposed the concept formally before the CRMC Polfcy and Plaming Comnttee, the CRMC leadership had been pecullarII insensitive to criticism offered in the best interest of the management process. On one occaslon, the debate reached the public's attentIon, when on June 21, 1979, at the Office of the Rhode IsIand Stateride Plaming Program during a meetfog of the State Plaming Coumct's Technical Committee for A-95 Review, it was reported by that agency's planning staff that the CRMC's existing permit system costs approdimately $\$ I, 000$. per permet to operate and causes delays in the dectaton-making process and to applicants. These criticiams were substantially acknowledged by a high-level officlal from the State Department of Cowmuntty Affairs and the Governor's Coastal Program Manager, and were reported in the Provldence Journal the following day.

A rebuttal was prepared for the CRMC and forwarded by the Counctl to the Governor on Iune 28, 1979, stating that the cFlticism was "unIustefled and that the Federal Office of Coastal Zone Management Section 312 findigge (of Apri1, 1979) were "directly opposite" those re32

ported at the Techofeal Commlttee. The letter to the Goveraor went or to clatm that the Rhode IsIand Program is a "model" program. 
Contrary to the effort of the CRMC to discredit the report on Jume 21, the cost of processing one permit was, in fact, estimated at $\$ I, 000$. by the Federal Office of Coastal Zone Management in its Section 312 (COMA) Eladings of Apr1I 19, 1979.

That report also concuuded that the processing time for permits was "rapid" having been reduced from 60 days to "almost 30 days as a result of staff additions." 34 Because the source of OCZM's informaEori is the state program partlelpants, one wonders why the program had not challenged the Sectlon 312 findings while they had been avallable in draft or even final form with regards to the cost estimate, If that estimate was erroneous. Also, since the state was the source of the estimate for permit processing time, one becomes suspicious of the verfty of the claim that the processing time was 30 days. Documented matertal for calendar year $1979^{35}$ reported that the average processing time for appIfcations that had reached a decision was 83 days, and that this group represented ouly 62 percent of the total appllcations recelved. Another 38 percent or 95 applications were reported as still pending at the time of that sampling (at year's end), and discounting these most recently received, 88 had been pending two or more months. Fifty-aix percent of the pending cases had been in the process for more than three months. The average time pending was 4.5 wonth. These figures are in stark contrast to those reported by ocze (for 1978), and $1 t$ certainly appears that the letter of Jume 28, 1979. reflects elther Ignorance of reality or a bold coverup of the facts. 
TABLE 1

1980 CRMC MEEIING WORKLOADS: Applications Reviewed

RESULTS OF MOVING TO TWO MEETINGS PER MONTH

\begin{tabular}{|c|c|c|c|}
\hline MONTH & $\begin{array}{l}\text { FIRST } \\
\text { MEETING* }\end{array}$ & $\begin{array}{c}\text { SECOND } \\
\text { MEETIYG* }\end{array}$ & TOTAL \\
\hline February & 12 & 4 & 16 \\
\hline March & II & 4 & 15 \\
\hline AprfI & 8 & 5 & 23 \\
\hline $\operatorname{mag}$ & 10 & 8 & 18 \\
\hline Itere & 8 & 5 & 13 \\
\hline July & $T$ & 10 & 17 \\
\hline August & 6 & 9 & 15 \\
\hline September & 9 & 8 & 17 \\
\hline October & I2 & III & 23 \\
\hline TOTAI: & 83 & 64 & 147 \\
\hline
\end{tabular}

PERCERT: 43.5

* As a result of moving to two meettags per month, the Council processed 43.5 percent of the caseload at the second meeting of the month during the pertod examined. Estimated days delay prevented: 17 days per applfcation based on a halving of the approximate 35-day delay applications that could occur under the one-month meeting schedule. ${ }^{2}$ 1 .

\section{Savings: $17 \times 64=1,088$.}

Wowes: 1) Tabulated from CRoc agendas February through October, 1980.

2) Bstimates derfived by Coastal Resources Staff and reported in Dfoiston of Coastal Resources Anmual Report for Fiscal Year 80. 
These findings are even more startling if one considers that the permit system produces very predictable results and that on the Iandalde of the Coestal Zone, the RICRMP Itself leaves "use" determination to local goverment. The CBMC will not accept an applicatom for a landside project until all other approvals, such as approval from the local bullding official and ISDS, have been obtained.

Another sample was taken on November 12, 1980 (Table 2). of the 215 cases handled by the CRMC between January 1, 1980, and the anple date, nearly 60 percent had reached a dectsion. The average Iength of time requited for a decision in these cases was 96 days (3.2 nouths). Of these, 82, or 38 percent of the sample, reached a decls1on withln 75 days. Out of these 82, only 2 went to a Public Bearting, and they were completed withln 61-75 days. When compared Wth the 128 dectsions found in the sample, cases concluded within 75 days represent 64 percent of the dectded appIfcations.

Stanficanty. nenly 15 percent of the declalons reached required more than 166 days ( 5.5 months), and 58 percent of these more lengthy cases were products of the public hearlng process. ThIrty percent of aII cases dectded in more than 75 days went through the hearling process.

Thare ware 87 cases pending at the date of the sample, representIng 40 parcent of the smpIe. Thist)-one percent of these (40) vere peading for more thar 181 daya (6 months). The average Iength of time pending was 176 dage or nearly six months. Of the 87,42 percent were - out to hearing. However, when those cases pendlog less than 75 days 
TABLE 2

\begin{tabular}{|c|c|c|c|c|c|c|c|c|}
\hline $\begin{array}{l}\text { TPRE } \\
\text { PERIOD } \\
\text { DAYS }\end{array}$ & $\begin{array}{c}\text { Ho, or } \\
\text { DECI8ION8 }\end{array}$ & $\underline{\mathbf{z}}$ & $\begin{array}{l}\text { PEHDING } \\
\text { CLSES }\end{array}$ & $\underline{z}$ & $\begin{array}{r}\text { DECISION } \\
\text { AND HAD } \\
\text { HEARING } \\
\end{array}$ & $\begin{array}{c}\text { PBRCENT } \\
\text { ATTRIBUTABLE } \\
\text { TQ HBARING } \\
\text { PROCESS } \\
\end{array}$ & $\begin{array}{c}\text { PELDING } \\
\text { HAD OR } \\
\text { OUT TO } \\
\text { HEARING } \\
\end{array}$ & $\begin{array}{c}\text { PERCENT } \\
\text { ATTRIBUTABLE } \\
\text { TP HRARING } \\
\text { PROCESS } \\
\end{array}$ \\
\hline $\begin{array}{c}30-45 \\
46-60 \\
661-75 \\
76-90 \\
91-105 \\
106-120 \\
121-135 \\
136-150 \\
151-165 \\
166-180 \\
181+\end{array}$ & $\begin{array}{r}26 \\
28 \\
28 \\
7 \\
6 \\
6 \\
5 \\
3 \\
6 \\
6 \\
13\end{array}$ & $\begin{array}{c}.2037 \\
.2187 \\
.2187 \\
.0546 \\
.0468 \\
.0468 \\
.0390 \\
.0390 \\
-.0 \\
.0468 \\
.1015 \\
\end{array}$ & $\begin{array}{r}10 \\
10 \\
6 \\
3 \\
5 \\
2 \\
4 \\
6 \\
1 \\
0 \\
60\end{array}$ & $\begin{array}{r}.1162 \\
.1162 \\
.0697 \\
.0348 \\
.0581 \\
.0232 \\
.0465 \\
.0468 \\
.0116 \\
-. \\
.3125 \\
\end{array}$ & $\begin{array}{l}0 \\
0 \\
2 \\
0 \\
0 \\
2 \\
0 \\
1 \\
0 \\
4 \\
7\end{array}$ & $\begin{array}{c}-- \\
. \overline{-} \\
.1250 \\
-\overline{-} \\
.1250 \\
.0625 \\
-\overline{-} \\
.2500 \\
.4375 \\
\end{array}$ & $\begin{array}{r}0 \\
0 \\
0 \\
2 \\
2 \\
0 \\
2 \\
4 \\
1 \\
0 \\
26 \\
\end{array}$ & $\begin{array}{c}-- \\
-- \\
-\overline{0} \\
.0540 \\
.0540 \\
-\overline{-} \\
.0540 \\
.1081 \\
.0270 \\
-\overline{.0} \\
.7027 \\
\end{array}$ \\
\hline TOTALA & 128 & .5953 & 87 & .4046 & 16 & .1250 & 37 & .4252 \\
\hline
\end{tabular}

MOTEs; (1) Tabulated from Diviaton of Coastal Respurces Staff prepared "CaMC Perm1t Log." Sample period 10 Januery 1, 1980, through November 12, 1980, and Includes alt cases logged durtng that per1od, Including case carried over from 1979 that went out to hearing in 1980. 
are removed from the total pending, the number pending/out to hearIng fumps to nearly $6 I$ percent. Of these pending/out to public hearing, 70 percent have been in the process for more than 181 days.

The effect of the hearting process on the length of time to reach a decision is clear. When vlewed by the average time for the sample, dectalons rendered through the public hearlng process required 7.4 months v8. 3.2 months for the uncontested cases. Cases pending/out to hearing have been so for an average of 9.2 months. And, the two cases dented required 10.3 month on the arerage for the dectsion.

Coupletely comparable data for any evaluation perlod is not ava11able. However, a sample of 128 cases filed at the Division of Coastal Resources as "1977 Cases," revealed an average (mean) processing time for all cases of 121 days or apprortmately four months. Cases that required publfc heartngs were processed in an average of 252 days or 8.4 months, while uncontested cases required 81 days or 2.7 months to Iecefve a dectalor. Becanse of the method of filing cases by the year of assent, the I977 sample included cases carrled over from 1976, and any ffles that were started in 197T, but were unresolved by December 31, 1977, were carfled into 1978. The year 1977 was chosen for the sample because it was the last full calendar jear before the state recelved federal can Section 306 funds. It was also the next 12 -month calendar jear after the IDOC Crit1que of the Bhode IsIand Program, based on preJulf. I976, cese Ioad analyats.

The 1980 data reveals that there bad been a lengthening of the the required to process cases when the "pendfng cases" are considered. 
On the basis on just those cases that actually reached a decision, the mean processing time in 1980 was slightly less than experienced in 1977.

One feature of the processing system that drfves up the administrative costs and reduces the overall efficiency and possibly the effectiveness of the program is the requirement that subdivisfor receive an overall review for roads, ut1litles, dralnage systems, etc., and then each lot is revlewed on a case-by-case basis when it is time for the drelling to be conseructed. This is a rather Iong-standing procedure that was enumclated in a letter to the Tfverton Tow Planaing Board by the CoMC Chatrman for the Winnisinet Parms subdiviston, Phase I (F1le 77-6-6). That project recelved an assent for a 10-10ch storm dratn after the staff biologist had reported a salt marsh violation. The Chatrman wrote that "each lot in the subdivision that comes under our jurlsdiction will be handled separately."

The Counctl has now under consideration an application (Chase) for a singIe-fantIy dwelling untt with ISDS in Winnisimet Farms which Is within the CRMC's furisdiction, but was started with a IocaI buflding permit, but whhout a state assent. The applicant's drelling is in a "W" hlgh-hazard flood zone where dwellings are required by the "Rhode Island State Bullding Code for Construction in Food Bazard Areas" to be elevated od pilings. The applicant has conatructed a couventlonal foundation. Moreover, Fleld Reports from the staff engtoeer and blologlst state that site preparation work has resulted in the bulldozing of 20 to 30 feet of salt marsh. 
The Winntsimet Farms case more fully 1llustrates the impract1callty of the case-by-case approach when, three years later, the developer is now attempting to start another phase of the subdivision. If pormtsstble uses were agreed upon and standards were in place, there would be IIttIe question of what to expect on the part of all cttizens, Including developers, and the preservation of coastal features may be more assurediy protected.

The Wimiolmet Farms case is not unique, as at least one of 1 ts tjpe occure amualIF. In I979, almilac altuation occursed with Ifghtbouse Point Subdiviator in Barrington (FIle 79-2-16) for whtch etght bouse Iots w111 require separate assents. The flrst brs occurred, much to the aurprlse of the developer (F1le 81-1-2), and that was found to bave flolated the Conservation easement mandated but poorly reflected In the 79-2-16 dectstor. - Arother subdivis10u was pending action in Kmeh, 198I. Called Eerncliff Farme in Warren, four Iots, two drafnage outfalls, and utflitie fall with the CRMC's furlodiction (out of a ren Iarge medim density development extendlag upland nearly one-balf afle from: mean blgh water). InIese the CounctI moves to correct this adniolstrative deflelency, the four lots will require separate permits when they are to be developed (F1Ie 81-1-7).

\section{Letters of Ro Objection.}

Section: 120.0-21 and 120.0-2C1 of the RICBMP have essentially extured all activities wibln 200 feet of patural system defined as beaches, burrter beachas, Clffs, Iedges, coaseal vetlands, sand dunes, and "all directly ansoctated areas contiguous to and necessary to pre- 
serve the 1ntegrity of such areas and features."36 The language in 120.0-2Cl is explictt in requiring a Council Permit, and while the GIossary does not define "Permit" or "Counc1l Permit" Appendix B: Management Procedures establishes a falrly well defined course of acHor to obtain one. Letters of No Objection are not clted in the RICRMP as a tooI of the Management Program, but they apparently have the same effect as an Assent.

Letters of No Objection have evolved as an adminlstrative device to procese activites which are belfeved to elther lie beyond the furindiction of the Gruc; is an activity or use not spectfically cited in the statute; are not wthle the 200-foot zone created by Section 120.0-2 of the RICRMP, or are Fithin the 200-foot zone but clearly such an innocwous use or activity as to not warrant consideration by the CRMC. The "letter" has evolved on an ad boc basis with no distinctive criteria spelled out to gulde the procedure for 1ssuance, and, Importantly, to enable two or wore individuals with very different educational and employment backgrounds and varying philosophtes about resource management and perbnps even Iffe expectations to visit a particular site and arrive at seme or sintiar conelusions.

The Cosstal Prospectus established as one of the top priorfty items before the CRMc, the developrient of criterla to screen out what should 80 bafore the cous and whet could Instend be bandled at the staff level. Th. cvoluefor of the Inteer of Ho Objection eseentially demonstrates that the Prospectus we correct in Identifying this critical need, but the Ietter proceas as it is currently implemented falls far short of 
being what the Prospectus appears to have envistoned.

An examination of the Eetter of No Objection 1ssued by the CaMc from July, 1979, through August, 1980, shows that 102 letters were fsaued durfing that 14-month per1od, (Table 3), averaging out to approximately 7 per month. The flrst feature of the "Letters" that becomes obvious is that there is no paucity of examples. where profects falling Into nearly all categorfes have been sent out to the 30-day Notice perIod and racefred the full Exentment. Other observations on the "Ietters" are: (1) sowe, but nowbere near all, have at1pulatlons attached governtis one or soveral appects of the project, as lts time frame or site impaet mitfigation procedure; (2) too many of the "Letters" are so loosely witten as to convey to the reader absolutely no 1dea of what profect 1s recefving the letter, and while thls toformation is supposedis avallable In the flles at the DIVLs10n of Cosstal Resources, the letter 1tgelf is beatcally a blank check to the reclplent; (3) not all letters have a turn-around tro that would Iodicate an advantage of the "Letter" ro. "Whe Botlee" if mearured by the alone, because there are a fen: canes where more than 30 and 40 days were requfred to get the letter out. (ro'C'S'IE Restuarant, GaIliee, for a deck and the Narragansett Inx, Westerly, for a deck addit1on), from the time the applicants first made contact with the management process.

\section{Cene and Destet Orders.}

Muen a part ts detected by the Program personnel to be in vlolaeton of the RICDap, they are Issued a Cease and Destst Order and are requited to perform one or more of the following actions: (I) submit to 
TABLE 3

INVENTORY OF LETTERS OF NO OBJECTION

JULI 1979 - ADGUST 1980

No.

OF

CATEGORY OF ACIIVIIY

CASES

Construction of SFDd/ISDS. .................................

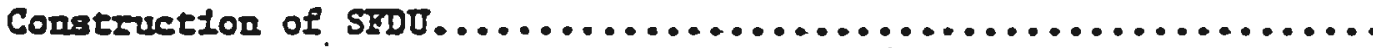

Construction of $k=c e s s o r y$ Structures, and/or foterfor and

exterlor bufldtng modiflcat1ons...........................

Ratse dwelling and/ve construct additions......................

Conatruction of, repatr or enclosure of porches.................

Construction of deck addittor to house or commerctal bullding

(I.e. restamrant)

Gencral bullding repatrs (1.e. repals, fire damage) ...............

ISDS repatrs..................................................

Repals of shoreline protectlon factIft1es and boat ramps.........

Repalr of plers, docks, dolphtos, etc...........................

Installation of temporary floats.............................

Activity uspectfled by the letrer...........................

Beach malntenance (public and private).......................

He-1ns wth etty sewer s.retems.............................

Construction of commerclal/Industrlal butldings................

Installatton of plifngs...................................

Mntntenance dredging........................................

Power Itre mafntenance......................................

Subdivision work beyond 200 feet..............................

Installation of a $60^{\prime}$ \& $80^{\prime}$ garden..............................

Eydroclectrte repatrs and/or installation..........................

Conseruction of a parkfng lot.....................................

Installattor of a drIveway adfacent to wetland...................

Beseareh work................................................

CAIV Tower..................................................

Removal of plpeltnes and wooden dry cargo platform...............

Removel of wood groln..........................................

Repals of dralnage outfall ................................

P111..................................................

Sewege Disposal System Installation "Other Facilttles"...........

Trato Irack Layout.

TOTAE:

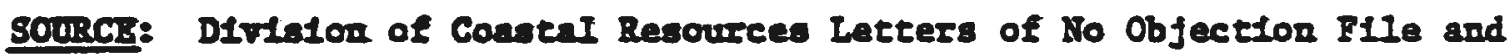
Ciav. General Correapondence F11e

Preparation Date: Octobar 2, 1980. 
the CRMC staff plans and/or an explanation of the activity; (2) submit an application to the CRMC for processing and eventual CRMC acElon (approval or denial); and (3) remove the 1llegallty and/or restore the area disturbed by the activity that prompted the Cease and Desist:

The effectiveness of Cease and Desist Orders has been examined several times over the past four years. An evaluation conducted prior to Hey. 1978, by the Retural Resources Defense Councll concluded that they are in effective mathod of balting cosatal vlolatlons. 37 Howcrer, If 1979, It wa discovered by state investigators that there was a practice of lsaufing "verbal" as well as "written" Cease and Desist Orders; and as one might expect; Flolaters clearly did not respect 38

verbal orders. There was mounting concern In 1979 that the extent of IIlegal activities occurring within the CRMC's furlsdiction was intolerable, a phenomenon acknowledged by a Providence Journal Company reportar, ${ }^{39}$ and Irvesetgated by the GAO (In an unpublished and class1fted report) Ir. the third quarter of the year as a part of an overall program evaluation. In response to these pressures, the Divtsion of Caneal Resources asetgeed a staff person to matntaln the Cease and Desist filing spstem, to Investigate complatnts, and to montor plolat1ons- Eventually, Ocax's Sectlon 312 evaluation of the 1979 Program jenr determined that "at least two weeks routinely elapses frow the date the violntion is dectected wetl the oxder is in the hands of the roponible party. 40

$$
\text { Durfing 1979, } 71 \text { Cease and Desist Orders vere issued by the GRMC. }
$$
The largest category of vlolations representing 30 percent of the total 
involved illegal fillings or alteration of coastal wetlands. When combined with other 1llegal shoreline alternatives and f1lling below mean high water, this category expands to 40 percent of the total. This is particularly significant because of thirteen Prohibitions and Special Exceptions established by the RICRMP; one clearIy states that distwrbances to cosstal wetlands is permitted only where a benefit to public welfare 1. demonstrated and no reasor zble alternative extsts. Moreover, these actfolties are clear vlolations of the State Guide Plan, Shore Regtor Polfey No. 5, whtch prohtbits filling of coastal waters and coastal wetlando unlese there is a public benefit and there is no 43

rensonable alternativia The Cauc is legally mandated by its statute to conform to the Stene Gutde Plan policles.

In 1979, 44 veariy 19 percent of the Cease and Deslst Orders were lasued to partles whlch had recetved an assent from the CRMC for some type of rork, but then proceeded to efther vlolate assent stipulations (592). or engage in nonauthorlzed activities (417) which fncluded 11Iegal fiIIfog of wetlands, barfler beaches, alterations, construction of manthortzed walls, IIIegal filling, erosion and sedimentation causIng activites, and dratnage outfall problems.

of the Cease and Desist Orders 1s8ued to partles that did not have - prior assent. 27 percent involved some form of construction activity or Ind such as afogle-fantly drelling untts. These types of actiflLee invatably require local bollding offictal approvel, which under the crac applleation procedure is necessary before the Gauc will accept an application. The Council accepts, and, in fact, requires that 
the local offictal only issue a letter stating that conformance with local codes and ordinances has been attalned. The actual local permit is then issued after recelpt of the CRMC permit. In these 19 cases comprising the $2 T$ percent, the local permit was issued without the GaMC permit. An analysis: (Table 4) of the Cease and Desist Orders, orders to remove, and orders to restore issued from January through October, 1980, determined there were 109 vlolations detected 45

by Program personneI. Seventy-three recelved outright Cease and Dendat Orders, whlle the balance were orders to remove or restore, or In con caes, there vere merely letters noting particular violatione and requesting a halt or a removal and directing the party at fault to appIy for an assent. When all 109 vlolations are considered, they represent approxfmately one-third of the case load for that pertod as measured by appltcations, letters of No Obfection, Cease and Deslat Orders, and Orders to Restore. When Cease and Desist Orders are considered alone, they represent 23 percent of the case load, and durfing the ample pertod, nearly 15 percent of all the applications were result of activftles halted by Cease and Desists. (Table 5).

The monthI rate of Issuance of Cease and Desist 1s up from 5.8 in 1979 to T.3 over the first 10 months of 1980 . This is a 25 percent incresse, and it cm be attributable in part to the addition of the otaff ansigment in Hovember, 1979. That asefgment colncides web in observed fincrease in the monthly tsauance of Cease and Desist Ordere frow 3.8 to. T.9, In the last elght months of FI 80 , an io cièse of more thar 100 percent. Moreover, all of the orders to restore during II 80 occured after that time. 
Several observations were made during the preparation of Table 4. Pirst, when a Cease and Desist Order $1 \mathrm{~s}$ witten up and matled to the vlolator via reglstered mall under a transmittal letter, there ts no scarcity of examples where the flolation descripttor is so vague as to be nearIy meaningless to the reader. Thts is the same phenomenon observed with the letters of No Objecton, and while documentation exdsts in the office on the nature and extent of the violation, materlal sent to the violator should be clear and spectfle. Second, it is documented that many. Cease and Dastst Orders are for activities that other individuals receive assemts and/or Ietters of No Objectlon for. Thls is particularly true for activitles in Category 5 (Table 4) which represents the second Iargest type of Flolation, wth 28 percent of the total observatons. With the exceptlon of those cases where a direct threat to or damage of a coastal physlographlc feature (or work below mean high water) Is occurring, all activities in Category 5 are eligible for a Ieter of Mo Objector. But, thls phenomanon is not restricted to that category, because a quick check of the letter of No Objection (Table 3) reveals people authortzed to dredge, repalr seawalls, remove vegetation, and place floats and piles without benefit of a 30day Notlce perlod.

The Incuing of Cense and Deslst Orders, in many cases, appears to be pat and parcel of an adminintrative process that consista more of requifing people to touch base than it is comprtsed of sound, costeffective euvifommental protection and management. An examination of the Cesse and Destet Orders that resulted in applications supports the thests that Iocal zoning is the determinant of use. It also supports 
IABLE 4

INVENTORT OF CEASE AND DESIST ORDERS/ORDERS TO REMOVE AND RESTORE

IANUARY 1980 - ADGUST 1980

TIPE OP VIOLATION

I. Piling or dump:ng

- below MHW o: in marsh

- above MHW adjacent to marsh or MHW

- not spectified above or below MHF
PERCENT

FREQUENCT

TOTAL

Subeoeal .......37

34.0

2- Desent VIolatione

-below MAIT

-above MAT

-mopectfled types

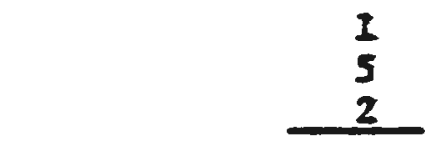

Subtotal.......8 8

3. IIIegal dredgtng or dredged materlal

disposel

4. Shoreline protector factilties

new

-repafrs to exdsting atructures

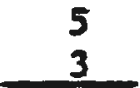

Subtotal_........8

5. "Construction" Actifities

durellting (new)

- mopectfied butldings

drelling additions or renovations

- unpectfled construction work

-peving ares of residential lot

-filling and grading

-removal of brush and trees

-Inidscaping and/or alte work

(1.e. cuesvation)

$\therefore$-inetaliation of a septle syotem. .........

$$
\text { a }
$$

subtotal.

6. detivity on a phyafographle feature

F. Illegal materiats (placed somewhere whth 200 feet) 
TABLE 4 (Con' $t)$

8. R.O.W. blocizage

1

2

I

10 boatramps

12. IIlegal prams, boats, and rafts
1.0

2.0

1.0

9.7

$3.0 \cdots$

rorat.....109

Preparattor Date: Oetober 14, 1980

Sourcer Division of Cosstal Resources 
the argument that the RICRMP is an environmental impact mitigation program as it affects most actiolties, and that it directly concerns use of and impacts only on physiographical features, and then aot exclusively. Frow December, 1979, through September, 1980, there were 45 cases put out to Nottce as a result of Cease and Desist Orders (Table 5). Durting that same perfod, there were 103 Cease and Desist irders 1ssued. Nearly 44 percent of the Cease and Deststs resulted io applications, and of these, as of November 21, 1980, 55 percent had recelved assents, 13 percent were pending action, 4 percent mere ordered to restore, 7 percent were ordered to restore prior to recelpt of thelr asaent, one application was wthdrawn after dental at the Canc subcomittee Ievel and resubutted by the applicane (an Increasingly common phenomenon); and one application was denied. Forty-sir percent of these cases started because the projects had recefved a local bulldiag permit, or because they were locally sponsored as in the two sewer projects and the filling at Flelds Potnt. Not counting the peading cases, assents have beex Issued in 100 percent of the Instances where local approval 1nitlated the work.

Iot gurpristagIy, the welght of CBMC furlsdiction is most heavily felt for activities that effect physlographlcal features and involve actfritles below mean bigh water. The restorations were to correct atverse Impace on salt marshes or for 111 gal unecessary Ifp rap. The applfestion dented at the subcomittee level and subsequently withdren and then resubutted lovolves a proposed atngle-family dveling unte on at that is predomfoted by wetlands and is characterized by an apparent lack of butIdable space. The dental val for 1 Ilegal gravel fill beIor mean bigh weter in an effort to shore up a falling bullehead. 


\section{TABLE 5}

APPLICATIONS RESULTIYG PROM CEASE AND DESIST PRDER6

DECDABRR 1979 - OCTOBER 1980

II

No

LANS

$79-1-13$

$80-2-3$

$80-3-26$

$80-4-15$

80-4-13

80-5-2

$80-4-16$

$80-5-12$

80-6-7

80-6-5

$80-6-16$

$80-7-7$

80-7-8

$80-8-6$

80-7-19

80-1-5

79-9-6

79-4-19

80-1-14

$80-2-6$

\section{8cerdurto}

Wilder

Meehon

Kort1ck

Tacy

Kuno

Burne

Aver Dend

Cemptery

Rlemer

Steere

Carr

Marctapo

Pray

Chapraan

Dare1Lue

Ga111ea Basch

Company

Rittex

Gencarelle

Montalto

Newport

Andruchow

\section{PROJECT TYPE}

SEDU/ISDS*

SEDU/ISDS*

Pler, float

Dock, float

SEDU/ISDS Eropton/rodimentation

SFDU/ISDS*

Bullding addition. ISDS brueh in marah

Brugh In marsh. develop 9 acreo

P11led land

Rip rap wa11

RIp rap wa 11

Dock extension, f111 in parsh

SEDU on new foundatton

Line malntenance, Harragansett Blectric

Sign on beach

81gn on Beach

Building additiont

Grave1 f111

RIp rap wa11

Sewer Intercepter

Rehabilitate SPDU
COMUNITI

Merraganaet:

Hey shoreham

Heater ty

South K1ngetown

Warwick

Charleatown

Narth Kingetown

Heater ly

Barr Ington

Narraganget

Narraganaett

Char lestown

Brfatol

Narragansett

Narraganaet

Narragansett

Newport

Charlestown

Weater $1 y$

Newport

Charleatown
CRMC

\section{ACTION}

\author{
Asgent \\ Assent \\ Absent \\ Assent \\ Assent \\ P
}

Restored/Assent

Restored/Assent

Assent

Assent

Assent

Restored/Assent

Assent

Assent

P

Aseent

Assent

Ordered to Restore

Assent

Assent 
TABLE $5\left(\operatorname{Con}^{\prime} t\right)$

FILF

No

MAME

80-2-7 V1gra

80-2-8 \$1mon

80-2-22 Bowman

80-2-1 Capr10, tt, al.

80-1-21 810n

80-3-9 Narraganpett

80-3-8 Providence

79-11-9 LaPrade

79-11-8 LaPrade

79-9-9 Glanotet

79-5-31 Raninakt

80-5-9 Water 8t. DQqk

80-9-5 Winpcker

80-8-9 Jagaclak
PROJECT TIPE

Rehab1fftate SFDU

Rehab1lttate SFPUћ

Rehabilftate SPpUt

Pooli geawall repalr*

Pumping station*

F111*

SFDU/ISDS Gtte Work

SFDU/ISDS Sit Work

R1p rap

Below MHW Bank fun gravel

House on new foundaftopt

Erogion on APR

SFDU/Hold1ng tank

\section{COMMUNITY}

Chef leatown

Charleatown

Charlegtown

Narragansett

North KAngatown

Narragansett

Providence

Warw1ck

harw1ck

Charleatown

South KAngstown

Warren

Narfaganaeft

Barrfagton
GRMC

\section{ACTION}

Aseent

Aseent

Assent

$P$

Aseent

Assent

P

Assent

Withdrawn

ordered to Restore

Den1ed

Assent

Assent

P

\section{$P$ - Pending \\ - - Sterted with local butlding permif of commulty apopared}

Preparation Dates November 3, 1980

Source; Diviaton of Coastal Resourcer 


\section{E. Public Hearings.}

Public Hearlags are beld on applications which incur an objection dwing the 30-day Notice perlod, or at the personal request of any CounetI member. AII obfections are considered vaIfd, but should spectflcally request a bearting, a step which is not always taken by the objector.

Burfing the sample pertod, December, 1979, through November, 1980, 76 applticatowe went out to hearing. The standard operating procedure at acering is for three Gay rembers to act as a fwy or bearing body utth legal comsel assistance. AII hearings are recorded by a atenographer and are attended by the Division of Coastal Resources Culef, Staff Englneer, and upon request, staff blologist. A practice whtch is now evolving is the subpeonating of all partles which submit afgned reports for the record, regardless of content, at the request of attorneys repreaenting the applleant or the obfector. AII hearings are advertised in state and IoceI newopapera and are generally beld in pubife bufldinge in the evenings. The hearlngs, often the result of Iocal or nefghborhood animositles, can be often characterlzed as stallIng techntques or harasument of appllcants by local partfes, and genarally result in ittele or no nes information. In comerctal water-

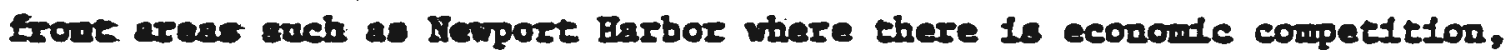
an obfection fron i local compettor can result in economie coste to i. appltemt whose profect is delayed, and one can logleally asaume, algotfient conoule gath to the competition. 
Cases put out to hearing clearly fall into categorles defining major and Insigniflcant types of considerations. Major cases out to public hearlags can be deflned as all those lavolving one or more of the following: (I) fiIIIng below Mean Elgh Water; (2) adverse Impacts on elffes, bluffs, salt marsh, or "contfguous wetlands;" (3) barrler beach deveIopment that confIlcts with the RICRMP; (4) erosion control projects that conflict whh the RICRMP; (5) major comerclal boating factIft expanaton or development; (6) aquaculture; (7) demonstrable nogative water quality impacts; and (8) any activitles that causes the staff to grigger the berden of proof requirements of the RIGRap.

Based or this catensive definftion, only 23 of the 74 cases in the anmile perlod required a public hearing. This represents a 68.4 percent reduction from the 12-month experlence. At the estimated cost of nearly \$600.00 per hearting (Table 9), this would be a savings of nearIf $\$ 30,000.00$ over the 12-month per1od. Th1s estimate falls to account for any outcom of the Boster Cove Cases, but there is IIttle Ifkellhood that any of those casen w1I be dented or severely modified as a reault of the hearing process. A wuch more Ifkely outcome will be assants wth ste fimpact mitlgatlon procedures stipulated in a manner not unItice alI residenetal development proposals. If, however, demonstrable adverse water qualfty Impacts are determined through the Foster Cove Canes, reouleting in. for nodification of an mforeseeable nature or ourfght dental. then a anfor precedent will be establinhed affecting alf future STDO/ISDS proposed on coastal ponds, because stmilar cond1tons adst elsewhere, gtven Rhode Island's coastal geologie hlotory. 
If the CRMC were to adopt stronger policies and regulations governing urban runoff, particularly as effects water quality through storm drainage projects, or as effects certaln sensitive natural areas such as the Narrow River or CoastaI Ponds, only one addittonal case would be added to the mator case definition shown in the accompanying table. The $5 I$ cases not defined as major have probably gone to hear- . Ing at a needless expense. Thls conclusion is also based on the finding frow a sample of those cases which went to heartng. An analysis of the flndinge. and recommendations of the full Council dectsion, compared with the inftial seaff findings and recommendations, found no Iack of casea where the dectalon reflects no new information obtained In the hearting and the legal staff relled soley on the staff reports. To 11Instrate, at the December 11, 1979, Counc11 meeting (IRANSCRIPI, p. 32) It was revealed, as one Counc1l nember put 1t, "No one came to the hearting to represent the Federated Sportsmen (an objector)...so, we fust talked to the applicant, and he agreed to all of the stipulatlone." At the February 12, 1980, meetlng (IRANSCRIPI, P. 30) durfog the reading of a subcointttee report or a publle hearing, it was revenled that: "the applleant showed and the obfector didn't... We did Ienrx thet (the applicant) wa a retired geveral. That is all we accomplished that eventng."

Yore Importantly, of those 23 cases classiffed as mafor by the defintefon above. 14 could poestbly bre been epared the pubIfc hearing procese. If there were in approved aquaculture plan in force and if the three aqueculture profects were in conformance with the plan, then wo heacting would bave been required. Such a plan is belng prepared by 
the Department of Environmental Management. The efght cases on barIfer beaches could also have avolded hearlngs based on the realization that these proposals are for dwellings which are, in fact, all permfted uses according to the RICRMP for the areas concerned, provided the standards estabIIshed by the program could be met. 48 So too, with the one case affecting a nonbarrler beach feeture because an alternative did exist for the applicant, thereby preventing use of the "no reasonable alternative" clause. Therefore, it is concelvable that the Council could have held only 9 public heartigs during the sample pertod, instend of 74 for a avolnge to the tarpayers of nearly $\$ 40,000.00$ in herring costa alone. This eatimate does not loclude the cost of legal counsel for the caxc at each bearing.

P. CRuc Profect Dentals.

The Gruc has dented approsdmately 30 cases in tts ten year's experfence (Table 10). Thls represents onIy 2 percent of the total number of profects thet were put out to notfce for public revier during that perfod.

Profect dentals are "IImfted" to those areas where the Counctl has cIear furtadiction, that 1s, below mean high water or on or dfrectly affecting a shoreline feature. The Decislons written for the denfals we structured Into sectlon offerring the Findings of Fact and Conclusion of Inw. Thts aeructure creater the framework to deliver the logic for the dental. At one tine, to 1975, the Counctl's procedures in 1te Insunce of dectstons was chastsed by the Court, because the declotor before the Court was "bereft of ang fact-finding" maktng the 49

"fudictal revter impossible" The declsions are now complete. The 
TABLE 6

POBLIC AEARINGS ON APPLICATIONS

FROM DECEMBER 1979 THRODGH NOVEMBER 1980

\begin{tabular}{|c|c|c|c|c|}
\hline EIES & IAME & PROJECI & LOCATION & $\begin{array}{l}\text { CRMC } \\
\text { ACIION }\end{array}$ \\
\hline $79-10-2$ & Deweldon & 56-Inte Condo. & Newport & aMf \\
\hline $79-9-30$ & Gianotel & $\begin{array}{l}\text { 2' Stone WaII w/ } \\
\text { Backf11I }\end{array}$ & Charlestown & $\mathrm{D} / \mathrm{OR} *$ \\
\hline $78-8-7$ & MaNultey & Macten & Portsmouth & $\mathbf{A}$ \\
\hline & $\begin{array}{l}\text { If ght Bouse } \\
\text { unselen }\end{array}$ & Brealorater & & - \\
\hline $78-12-4$ & FiIItim & $\begin{array}{l}\text { Calleged for agride } \\
\text { culture } \\
\text { 2. Plitioge }\end{array}$ & South Lingetown & $\mathbf{D}$ \\
\hline $78-8-18$ & Beadyhough, H. & SFDU/ISDS & South Kingstown & $\mathbf{A}$ \\
\hline $79-8-14$ & Beadyhough, J. & STDO/ISDS & South Rtngstown & $\mathbf{A}$ \\
\hline $79-11-18$ & Iindberg & SFDU/ISDS & Rarragansett & DC \\
\hline $79-11-19$ & Low & SFDU/ISDS & Narragansett & $\mathbf{A}$ \\
\hline $79-11-20$ & Comradf: & Verlan Expansion & Westerly & $\Delta$ \\
\hline $79-7-16$ & Creters, $\mathbf{B}$ & SLDU/ISDS Ox BB. & Block IsIand & 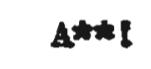 \\
\hline $79-9-17$ & Devereur, $\mathbf{R}$ & SIDU/ISDS OI BB & BIocts Island & $A^{*} \rightarrow$ ! ! \\
\hline $79-9-18$ & Devereur, R. & STDU/LSDS ox BB & Block Island & Atat! ! \\
\hline $79-9-3$ & Ganar & $\begin{array}{l}\text { STDU/Connected to } \\
\text { Sewers on BB: }\end{array}$ & Block Island & ND \\
\hline $80-1-1$ & $\begin{array}{l}\text { P. Toole } \\
\text { Pealtor: Ine. }\end{array}$ & Matneconoc/Floate & North KIngstown & $\mathbf{A}^{\star}$ \\
\hline $\begin{array}{c}79-12-8 \\
\therefore\end{array}$ & Sifth & SIDU/Addieton ISDS & Rarragansete & $\Delta$ \\
\hline $80-I-9$ & Quim & Aquned ture. & $\begin{array}{l}\text { Qutcksend Pond } \\
\text { Iftele Compton }\end{array}$ & $\mathbf{A}$ \\
\hline $79-8-I I$ & $\begin{array}{l}\text { Pe. Iudith } \\
\text { Sheilfish }\end{array}$ & 60' P1ar Btension & Portamouth & $\mathbf{D}$ \\
\hline
\end{tabular}


TABLE $6\left(\operatorname{Con}^{\prime} t\right)$

\begin{tabular}{|c|c|c|c|c|}
\hline FIIE & NAME & PROJECT & LOCATION & $\begin{array}{c}\text { CRMC } \\
\text { ACIION } \\
\end{array}$ \\
\hline $79-9-32$ & Envine Batates & $22 \times 24$ Garage & South Ringstown & $\mathbf{A}$ \\
\hline 9-9 & Hownerd & $\begin{array}{l}\text { Belocate SEDU } \\
8 \text { BufId AddI- } \\
\text { tlor ox BB }\end{array}$ & Charlestown & A \\
\hline 79-9-6 & Gencarella & $\begin{array}{l}30 \text { X } 30 \text { Gravel } \\
\text { F1II for } \\
\text { parktog }\end{array}$ & Charlestown & $\mathbf{A}$ \\
\hline $79-4-19$ & Sontalto & R1p rap wal1 & Westerly & $D / O E^{*}$ \\
\hline $30-1-11$ & Durahamel Trust & SIDU/ISDS & $\begin{array}{l}\text { Charlestown } \\
\text { (Foster Cove) }\end{array}$ & W \\
\hline $30-I-12$ & Dunhareal Iruat & SEDU/ISDS & $\begin{array}{l}\text { Charlestown } \\
\text { (Foster Cove) }\end{array}$ & $\mathbf{N D}$ \\
\hline 8-8-8 & Reegan & SEDT/ISDS & $\begin{array}{l}\text { Charlestown } \\
\text { (Eoster Core) }\end{array}$ & $\mathbf{N D}$ \\
\hline 79-9-9 & Boccusze1 & SFDU/ISDS & $\begin{array}{l}\text { Charlestown } \\
\text { (Foster Cove) }\end{array}$ & $\mathbf{N D}$ \\
\hline $79-9-10$ & DunhanaI Irust & SEDU/ISDS & Gharlestgwn & $\mathbf{N D}$ \\
\hline $79-9-11$ & Denbromel Irust & SFDO/ISDS & $\begin{array}{l}\text { Charlestown } \\
\text { (Poster Cove) }\end{array}$ & XD \\
\hline $79-9-12$ & Dromberiel Iruse & SEDU/ISDS & $\begin{array}{l}\text { Charlestown } \\
\text { (Foster Cove) }\end{array}$ & $\mathbf{1 0}$ \\
\hline $79-9-13$ & Eyde & SEDT/ISDS & $\begin{array}{l}\text { Charlestown } \\
\text { (Foster Cove) }\end{array}$ & $\mathrm{ND}$ \\
\hline $79-9-14$ & Dute Soon Kim & SEDU/ISDS & $\begin{array}{l}\text { Charlestown } \\
\text { (Boster Cove) }\end{array}$ & $\mathbf{N D}$ \\
\hline $79-9-15$ & Moran & STDU/ISDS & $\begin{array}{l}\text { Charlestown } \\
\text { (Foster Cove) }\end{array}$ & $\mathrm{BD}$ \\
\hline $79-9-16$ & Boche & STDU/ISDS & $\begin{array}{l}\text { Charlestown } \\
\text { (Eocter Cove) }\end{array}$ & SII \\
\hline $79-9-28$ & Krouse & STDU/ISDS & $\begin{array}{l}\text { Charlestown } \\
\text { (Foster Cove) }\end{array}$ & MD \\
\hline-9 & Starling & SEDU/ISTS & $\begin{array}{l}\text { Charledtown } \\
\text { (Foster Core) }\end{array}$ & ND \\
\hline
\end{tabular}


TABLE 6 (Con't

\begin{tabular}{|c|c|c|c|c|}
\hline EIIE & NAME & PROJECT & LOCATION & $\begin{array}{c}\text { CRMC } \\
\text { ACTION } \\
\end{array}$ \\
\hline $79-11-11$ & Du hamel Trust & SFDU/ISDS & $\begin{array}{l}\text { Charlestown } \\
\text { (Poster Cove) }\end{array}$ & ND \\
\hline $80-1-3$ & Barber & STDU/ISDS & Charlestown & $\Delta t+t / t$ \\
\hline $80-1-14$ & cIty of Newport & $\begin{array}{l}\text { Interceptor } \\
\text { Sewers }\end{array}$ & Newport & $\mathbf{A}^{\star}$ \\
\hline $78-1-1$ & Ray Cot Plber & $\begin{array}{l}4500 \text { ft. } \\
\text { FIII aree } \\
\text { below MHW }\end{array}$ & Warren & D \\
\hline $80-2-1$ & Caprto et. I. & $\begin{array}{l}\text { Cormerten } \\
\text { Addition }\end{array}$ & Narragansett & $\mathrm{SW}$ \\
\hline $79-8-10$ & SardeIIt & $\begin{array}{l}2640 \mathrm{gd}^{3} \\
\text { EtIt on } \\
\text { Lot }\end{array}$ & Marragansett & $\mathbf{D D}$ \\
\hline $80-3-1$ & Nunes & $\begin{array}{l}\text { Dockes, } \\
\text { Eloses, } \\
\text { wall }\end{array}$ & Bristol & $\mathbf{A}$ \\
\hline $80-3-2$ & Kropes & SEDU & Bristol & A \\
\hline $80-1-21$ & Stor & $\begin{array}{l}\text { Sutrupool; } \\
\text { sexwa1I } \\
\text { repatrs }\end{array}$ & North Ringstown & $A^{*}$ \\
\hline $80-1-24$ & Psov/DEMT & $\begin{array}{l}\text { Gravel Road } \\
\text { and park- } \\
\text { fng loe }\end{array}$ & Narragansett & SD \\
\hline $80-3-8$ & PEOV/DPW & $\begin{array}{l}\text { Unturafo FIII } \\
\text { Ares }\end{array}$ & $\begin{array}{l}\text { ed } \\
\text { Providence }\end{array}$ & $\mathbf{N} \mathbf{W}^{\mathbf{t}}$ \\
\hline $79-4-9$ & Periwinkle, Inc. & $\begin{array}{l}\text { Floats \& } \\
\text { P1lea }\end{array}$ & Newport & $\mathbf{A}$ \\
\hline $79-7-4$ & $\begin{array}{l}\text { South County } \\
\text { Sand } 8 \text { Gravel }\end{array}$ & $\begin{array}{l}\text { Hip rap } \text { FalI } \\
\text { Elese } 8 \\
\text { Ionts }\end{array}$ & South Kingetown & $\mathbf{A M}$ \\
\hline $80-3-18$ & $\begin{array}{l}\text { RToor Sprague } \\
\text { Betige }\end{array}$ & $\begin{array}{l}\text { Bridge on } \\
\text { Bt. I-L }\end{array}$ & Narragansett & $\mathbf{A}$ \\
\hline
\end{tabular}




\section{TABLE 6 (COD't)}

PIIE NAME

77-1-3 Dunphy

79-5-34 North Kingstowr

80-3-23 Fischer/Cranshan

80-4-3 F1sh, J.

80-4-4 FIoh, I.

80-4-5 FIsh, E.

80-6-9 Watch BtIT

F.D.

80-4-13 5imo

79-5-37 Booth

80-5-6 Shepperton.

80-I-10 Vaclavick

80-5-12 BIemar

80-6-12 VITber

80-6-II Conte:

80-6-19 Mnes

79-12-3 Galllean Seafood

80-7-1 Dubols

80-7-14 Bnetbet

80-7-16 G5=5

79-9-26 Ruse-Ruse

$$
\text { Eentt }
$$

PROJECT

RIp Rap WalI

LOCATION

CRMC ACTION

Nosqufto Ditehtog

North Rlagstown

$\Delta$

SEDU/ISDS on BB Charleatown ND

SPDE

Narragaisett

ND

Narragansetet. ND

Narragansett

S1D

I6 PlIes

Westerly

4

STDU/ISDS

Charlestown

ND*

STDU/v/drtveway through marsh

Barrington

AM

$4 \times 80$ Pler

Barrfongton

$\Delta$

Belocate SFDU of BB

Charlestown

ND

LegaIfze $10,000 \mathrm{gd}^{3}$ IIII on Lot

Barrington $\quad A^{*}$

STOU/ISOS

Charleatorn

PP

Crrage, Greenhouse, Patio

North Ringstown

SD.

suseeI Culture

Test Passage

SD

24 I 20 BId. Ad.

Narragansett

$\mathbf{A}$

SIDU/ISDS on BB

Westerly

RS

Srot on RHenar'

IIII

Barrington

$\Delta$

3 STOSE:-

Barrington

$\Delta$

$3100 \mathrm{gd}^{3} \mathrm{~F} 111$

below MAN
Brfstol

\section{D}

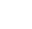

D



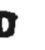

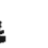

D* $M$

A

1

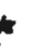

$\mathbf{P}$




\section{TABLE $6\left(\operatorname{Con}^{\prime} t\right)$.}

\begin{tabular}{|c|c|c|c|c|}
\hline EILE & NAME & PROJECT & LOCATION & $\begin{array}{c}\text { CRMC } \\
\text { ACTION } \\
\end{array}$ \\
\hline $80-7-21$ & Agnol1/Gulst1 & $\begin{array}{l}\text { SFDU/ISDS on } \\
\text { Sand SpIt }\end{array}$ & Warwick & ND \\
\hline $80-7-19$ & $\begin{array}{l}\text { Galtlee Beach } \\
\text { Company }\end{array}$ & $\begin{array}{l}\text { Private Property } \\
\text { Sign on Beach }\end{array}$ & Narragansel: & BB \\
\hline $80-8-6$ & Earaleus & $\begin{array}{l}\text { Private Property } \\
\text { Sign on Beach }\end{array}$ & Narragansett & BB \\
\hline $79-5-3 I$ & Raminsief & EIII below MHW & South Ringstown & $D *$ \\
\hline $79-2-14$ & RIDOT & $24^{n *}$ Outfall & Warritcle & $\mathbf{A}$ \\
\hline $80-7-18$ & Malenfant & $\begin{array}{l}\text { Rtp rap wall } \\
\text { Below MHW }\end{array}$ & South Ringstown & ND \\
\hline
\end{tabular}

Total Applications to Eearing in Sample Perlod: 74

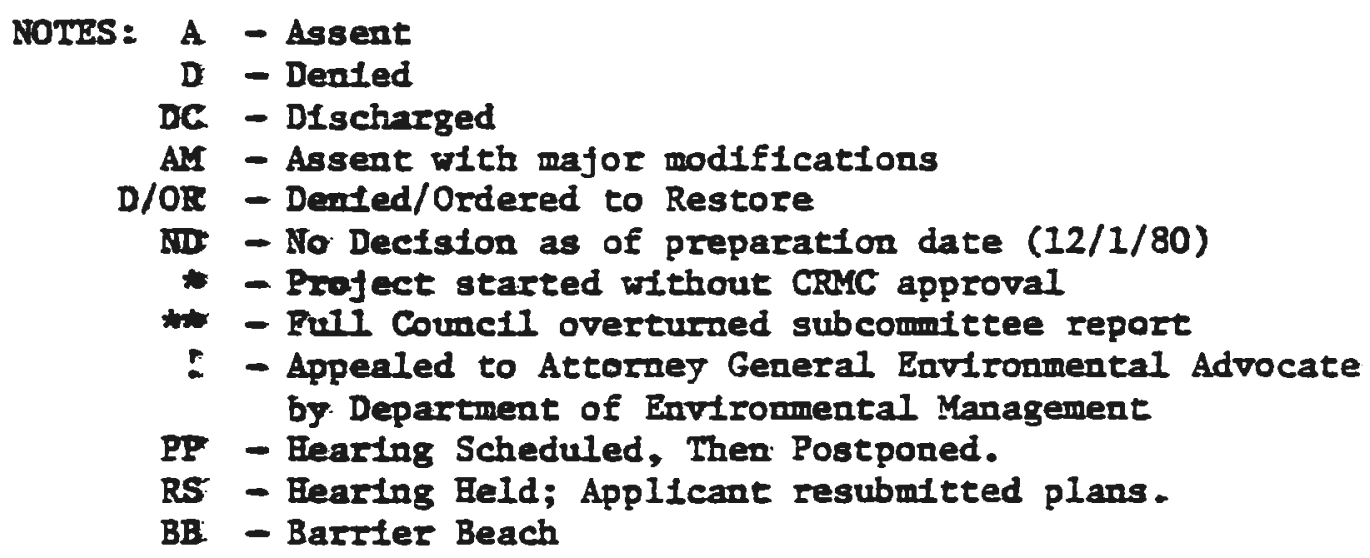

SOURCE: Difisfon of Coastal Resources Files.

Preparation Date: March 21, 1981 


\section{TABLE 7}

$\frac{\text { MAJOR CASES OUT TO PUBLIC HEARIVG }}{\text { DURING SAMPLE PERIOD }}$

PILITNG PROPOSAIS:-

Ray Cot Plber

Russ-Russ Realty

Kamins'e1

Malenfant

Gianote1

PROJECT ON BARRIER BEACH:

Daraleus 1

Gaftlee Beach Company

Carter $^{4} 4$

Devereur.

Devereyx 4

Gasner

Vaclavif ck 2

Dubots 2

EROSION CONTROL PROJECTS:

Montalto

South County Sand \& Gravel
AQUACULTURE:

Quinor

Williams

Macy

PROJECT AFTECTING PHYSIOGRAPHIC ERATURES (Other than Barrier Beaches)

Deweldor

Booth

AgroIf/GufstI

(1) Would not be mafor if RICRMP had spectfic prohtbltions on these projects (private property stgns or barfler beach). Hearlng based on precedent setting nature of profects.

(2) Should not be considered mafor because the barrler beaches are classified as "developed" where these profects were introduced. Cases went to hearing because the applicant chose to try to build on a Dume which is a probtibited use according to the RICRMP, Section 120. $0-2$, or in the Gasner Case, is on the "back side" of the Barrier and went out to hearing partly because of an unwitten policy to put all barfler beach cases out to heartag, and partly because of local problems.

(3) Should not be constdered major. The profect conflicted with the RICRMP and vas modifled to conform to the staff recommendations.

(4) Mafor because the applicants chose to butld on a dume, a prohibfted action. This barrier beach is described as a developed barrier and

it as such, residential development is permitted by the RICRMP. The RICRMP also shows the prlortty for use of the beach as Conservation Use. 
TABLE 8

CATEGORIZATION OF ALI CASES OUT TO PUBLIC HEARING

DURING SAMPLE PERIOD

DECEMBER 1979 - NOVEMBER 1980

BEIOW MEW

FIIIING PROPOSALS

Ray Cot Fiber

Russ-Russ Realty

Raminsk1

Malenfant

Glanotti
COMMERCLAL BOATING FACILITIES

Pt. Jodfth Shellfish

MeNulty

P. Toole Realtors

Perlwlnkle, Inc.

Watch Hill F.D.

Conradi

Numes:

PROJECI ON

BARRIER BEACH

Daraleus

Galilee Beach Company

Carter

Devereux

Devereux

Gasner

Vaclavick

Dubols

Howard

Plsher/Cranshaw

Tilbue

Galtlean Seafood
EROSION

CONTROL

South County Sand \& Gravel Montalto Dunphy

Bartbet

ACTUAL OR POTENTIAL ADVERSE IMPACT ON PHYSIOGRAPHICAI FEATURES ON MEW

Deweldon

Booth

Agnoll/Gulst1

City of Newport

Sion

North Ringstown

Fișh, J.

Fish, J.

Fish, E.

Envine Estates

Genoarella

Barber

Caprio

SardelII

Providence/DEM

RIDOT Bridge

Conte

Gray

ReImer

Providence DPW

CEIULATIVE

IPACI ISSUE

Sheppertor

\section{AOUACULIURE}

Quinm

WIIllams

Maç 


\section{TABLE 9}

ESTIMATED COSTS FOR A PUBLIC HEARING*

CATEGORY $\cdot$ COST

I. Copying Cost of Hearlng Not1ce (130 coples) .............\$ 7.00

2. Mailing, including postage............................. 22.50

3. Arrangements and delfveries........................... 15.00

4. Advertisements.................................... 60.00

5. Publication of 24 sets of Applfcation File............ 45.00

6. Average of 3 CRMC members in attendance at $\$ 50.00$ each... 150.00

7. Stenographer at $\$ 2.25 /$ page, plus $\$ 100$. to show......... 212.00

8. Overtime for State Civil Eng1neer................... 50.00

9. CRMC members' mfleage at 20 cents per mfle.............. 15.00

10. Executtve D1rector's MAleage............................ 5.00

11. Division Chifefs Mfleage............................. 5.00

12. Staff Bnglneer's Mfleage............................... 5.00

$$
\text { BSTIMATED TOTAL COST } \$ 591.50
$$

SOURCE: Divisfon of Coastal Resources, estimate by administrative persomnel.

* Mleage costs are estimated at 25 miles per person per hearfng. Actual cost-were not avatlable, and this estmate- is constdered to be extremely conservattve. To illustrate, for example, the conservative, there have been IQ bearfigs on Foster Cove, Subdivision, in Charlestown, Rhode IsInd. The Brecutive Director travels from Tivertor (97 mfles), the Division Chief traveIs from Providence (83 miles), the Staff Englneer frow Johnston (8I mfles), a CRMC member from Westerly (26 mfles), a CRMC nember from North Ringston ( 39 mfles), and a CRMC member from Warwick (50 miles). Distances shown are round-trip estimates on major highwas frow generalized trlp termint. Total average mfleage is 60 mifles per person. Mor does the total include the cost of the GRMC IageI coumsel present at each hearing. 
logic for denial is typically based upon conflict with the plan, faflure to meet evidentfary burdens of proof, a determination that the project will make areas unsuitable for uses and activities des1gmated by the management program, and/or that the coastal resources in a spectfic area are not capable of supporting a proposed activity.

The Council's dentals in two major cases lnvolving filling and/ or residential construction in coastal wetlands have been upheld in Court. Ir Dalmazio 0. Samtint V. John A. Lyons, et. als. (C.A. No. 74-3158, C.A. No. 74-3159, and C.A. No. 79-1162), the consettutomalfty of the Coumcll was upheld as was its authorlty to restrict the use of the marsh. The Court found that the applicant's "only restrsction is that he may not destroy a coastal wetland or Introduce pollutants in the waters that surround 1t." 50 The tak1ng issue was dismdssed in this case. In Sebastiañ Milardo v. The Coastal Résources Mamagement Coumc11, et. als. (C.A. No. 7T-735, and C.A. No. 77-2245), the Court found that "the creation of classtficatlons based upon reasomable conslderations is not unconstfeutfonal," and the CRMC is "not denying the platnetff all beneficlaI use of his land, it is only denyIng the opportunfty of Introducing pollutants into a public ocean area and a protected marshland area. This it has the lawful rfght to do..."5l

The constltutlonalfty of the Counell was also upheald in John A. Erons, et-als, F. Fmay BtIImare (C.A. No. 72-182). The Court noted there is a distinction between eminant domatn and pollce power. The power of eminent domalin, the Court stated, recognizes the flght to compensation while polfce power does not. Compensation arfses when restric- 
tions are placed on a property to create a public benefit rather 52

than to prevent a public harm. The Court noted in Nancy B. Fillmore y. John A. Iyons. et. als. (C.A. No. 73-2373) "that butlding permits lawfully tssued for a permitted use should be immune to impafrment of revocation by reasor. of a subsequent amendment to the zontng ordinance when the holders thereof...inltiate construction." 53 The Council's Cease and Desist Order on construction which had started on Green HIII Barfier Beach (South Ringstown) In the Fillmore Case was Iffted by the Court ruling in favor of the Plaintiff.

The Court ruIfng in the FIIImore Case has been clted by the Council as justification for allowing new construction on Coast Guard Barrler Beach (New Shoreham). The Councll wrote to the Prov1dence Iournal Company in September, 1980, that it "cannot Ignore the Superfor Court ruling that provides owners of developed barrler beaches a tight to ut1llze their property. The only legal alternative that GRMC has, is to purchase such property outrfght." 54 This positton appears to be supported by the Supertor Court Dectsion on Anntcellt, which foumd that a South Kingstown zoning ordinance prohibiting aII construction in high flood danger (EFD) areas-namely, barFler beaches. This includes Green HilI Barrler Beach, and the Court declared the ordinance as "an indirect, conffscatory taking of her property - without fust compensation," and concluded the town must exarctse eminent domain if it wishes to retatn the barrier beach in tec present state. 55 Thts dectsion is being appealed by the town and Amfcus Brlefs have been planned by the CRMC, the Rhode Island State- 
wide Planing Program, the Rhode Island State Department of Environmental Management, NOAA, and the Vermont Environmental Law School.

A pattern of confusion emerges from these cases with regards to the CRMC's abIIfty to determine highest and best use of precisely the resources it has clear furisdiction over. The takting issue has been successfully handled in decisions involving marshes, but not yet in cases Involving barrler beaches. Regulation of these physiographical features and, particularly barrler beaches, appears to be at the Iegal "frontler" in Rhode Island, Certainly, property owners must beware when they dectde to alter for prtvate use either a marsh or a barrler beach. The costs involved in legal fees and retainfing expert witnesses can be high. 56

FIve Council dectsions are fnstructive of what an applicant may expect. By examintig each case on Its merits, the CRMC technically camot be influenced by another dectston it renders elsewhere. This Issue 1s not so much the focus of these IIIustrations, as are the issues of a haphazard approach to the RICRMP Iequirements and discretonary action on the part of the CBMC.

In 1979, the Rhode IsIand Yacht Club proposed a major project at Its faclity in Stillhouse Cove in the Providence River, Cranston. The waters are classified by the RICRMP as an Urban Estuary, and shoreIfne dependant commerce and fndustry and the matntenance and expansian of approprlate recreational opportunitles are cited as compatible uses 57

of the water. The Yacht Club is the oldest in the State of Rhode IsIand, and the third oldest in the Country. It was ackowiedged 
by the objectors to the proposal to have been "floundering for many "59 years.

A mafor aspect of the proposal was the placement of 4,000 cubic yards of fIII into StIIThouse Cove to create some additional space for the Club. This was objected. to by Iocal residents as the Cove is "probably the only cove in the City of Cranston where th. public can ga and vlew its natural resources." 60 It was argued by a CKMC member that the CounctI's charge is, in part, to assure "all plans and programs shall be developed around basic standards and crtterla fncluded....the last of whtch reads consistency wh the Statewide PIaw," which contalns a polfey agalost filling coastal waters and wetIands. 61 The Tacht Club proposal was approved, modiffed to not include the fiII below mean high water.

The same night the Counctl dented the Rhode Island Yacht Club permisalon to EIII 4,000 cuble yards in StIIlhouse Cove, they approved Marine Syatems, Inc.' proposal to place an unspectfled amount of fill in an "ares 200 to 180 feet Iong by 30 feet deep," 62 in Point Judith Pond, an Area for Preservation and Restoration, and a Multiple Ose Recreation Coastal Pond where the deposition of fill is a low priortty use described by the RICRMP to "have the potentlal to disrupt or destroy the primary value of these estuartes and coastal ponds..." 63 The Staff Btologist stated: Minere is a signiflcant area of fill to be placed In. the shallow water area or what we call or refer to as the Ifttoral zone and this area has the potential of supporting a large population of mactne ammals." 64 But, the CRMC approved the fill, twat on the applicant.'s statement that if he were to.modify his pro- 
posal in accordance with the Staff Blologist's recommendations, it would "cause us financtal problems," 65 and a Counctl member from the locale speaking on behalf of the applicant: "Their proposal, I think, would be consistent with the type of establishments that are in the area at the present time." 66

Nottng the earlfer decision to deny fill in Stillhouse Cove because It violates the State Gulde PIan, one Councll member stated that "the Courctl would be putelng 1tself in an awful posttion to approve" the Marlne Systems proposal. 67 The Staterlde Plaming Program did not reference the Shore Region Polfcy to prevent filling of Coastal Waters and Wetlands in either case. Importantly, there was strong local objections to the Yacht Club, while only the staff objected to the Marloe Systems project.

In JuIF, 1977, approximately one gear before the RICRMP was approved by OCZM, the CounctI granted an assent for a single-family dreIIIng and ISDS ow a barrler beach in Charlestown, Rhode Island. 68 The proposial had received an object on from the Statewide Planning Program. In the review of the 1977 cases on file at the Difiston of Coastal Resources, It was found that in that year the state planning agency commented on slightly more than half the cases on file. When It did comment, the plantag agency offered major or substantive recomendattons for dental or requested that applicants be required to meet thels burdens of proof (Table 14). Those comments were part1cularly drected to construction on barrler beaches and the plaming agency suggested that if the CRMC feared the takdng 1ssue, there was aviromental case Iaw In other states that may be of benefit to the 
Council if it sought denial of barrier beach construction.

The assent for the dwelling and ISDS explred and was renewed to Iuly 14. 1979. The Assent and Renewal had stipulated only that the applicant maintain the project and that the Coumeil be notfifed wher construction was to comence and end. Because the Assent explred a second time, and the applicant had not inftiated construcHon, a new application for the project was filed. The project was put out to a publfe hearting on November 15, 1979, and the CRMC subcommittee recommended to the full Counct that the applfcation be dented becsuse "although the applicant was given every opportunity to present evidence in furtherance of this application, the record does not ladicate that sald evidence was presented, (and) that the recommendations and reports... do not indlcate that the activity proposed will be suitable for the coastal region." 70

When the Councll moved to accept the recommendations of the subcomifttee, it was pointed out by a CRMC member that the record clearly indicated that an Assent had been granted for the particular $\pi I$ activity. The council then effectively dismissed the recommendaHox to deng the proposal, even though that subcomititee had found that the RICRMP evidentiary burdens had not been met, ${ }^{72}$ and the Chatrmen of the Council issued a letter of Assent extenston. The extenator added forr new stpulatfons governing buflding elevation, site disturbence, protection of the dume, and use of vehfcles and equipment. 73 The Agsent was extended agatn a year later "wth all other provistons of the ortignal (emphasis added) Assent remalning the same," 74 thereby megating the: stipulatfons of the extension granted a year earlier. 
The Council demonstrated extreme latitude in this case. In another situation, an applicant had allowed an Assent to expire, and it was stated that "we can't extend something that has expired. We resolved that some time ago." ${ }^{75}$ The two actions do not appear at all consistent with each other, and one clearly appears to be not consistent with the RICRMP.

The Council dented a profect for a "floating dock, 4-feet wide, and 20-feet long to be buflt between two exfsting pilings near an already edsting doct, and two 4-foot wde, 20-foot long sections to be placed bestde this statlonary dock" proposed for the Pawturet Cove porttor of the Providence Rtver Urban Estuary. 76 The Counctl based Its dental on evidence that "the coastal resources would not be enhanced, nor would they be Increased in any aesthetic or recreational value and. would, in fact, be detrimentally impacted if this activity were to be allowed."77 The comell concluded that "the evidence does not show that the cosstaI resources in the spectflc area are capable of supporting the wthtr activity," and "more specifically, the appitcant has failed to demonstrate the effects the proposed activity wiII have or the coastal resources." 78

The proposal was, however, consistent with the RICRMP which finds that the mafntenance and expansion of appropriate recreational opportunteles are compatible with the Urban Bstuary degignation of the Cove. In 198I, the CruC approved a 165-foot pler extending into Parturet Cove on the property directly adfacent to the property involved in the denfaI. 80 One difference between the two cases was the local objection 
TABLE 10

CRMC PROJECT DENIALS

\begin{tabular}{|c|c|c|c|c|}
\hline YEAR & $\therefore$ MAME & PROJECT TYPE & MATERBODY/COMMUNITY & BILE NO. \\
\hline 7973 & 8fringer ${ }^{2}$ & SEDV/ISDS & Pofnt Judtth Pond/r- & $73-7-10$ \\
\hline 1973 & Lambert ${ }^{2}$ & SBDU/TSDS ${ }^{1}$ & 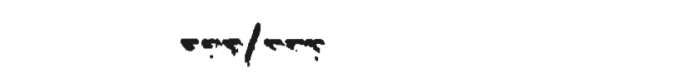 & $73-8-17$ \\
\hline 1974 & $\operatorname{Santstat} t^{2}$ & FILL MARSH & Polnt Judfth Pond/Narragansett & $74-3-3$ \\
\hline 1974 & Kagerch $^{2}$ & PIER & Green 4111 Pond/Sp̈uth Kingatown & $74-3 \div 11$ \\
\hline 1974 & C-Lark MarIna & $\begin{array}{l}\text { BULKHRAD \& FILL } \\
\text { BELOW MAW }\end{array}$ & Warwtck Cove/Warwlck & $74-2-6$ \\
\hline 1974 & $710 e^{2}$ & PIER & Pawtuxet Cove/Warw1ck & $74-10-10$ \\
\hline 1974 & Jaz10wieckt ${ }^{2}$ & SEDU/ISDS & Green H117 Pond/South K1ngatawn & $74-10-9$ \\
\hline 7975 & Stell1tang & FILL MARSA & W1nnapaug Pond/Weaterly & $75-5-6$ \\
\hline 1975 & Pond $^{2}$ & SEAWALL & Block Ioland Sound/Westerly & $75-11-2$ \\
\hline 1975 & Milardo? & SFDU/ISDS & W1nnapaug Pond/Westerly & $75-5-20$ \\
\hline 1976 & $J, J, J, C o r p^{2}$ & DREDGE & Wickford Harbor/North Kingstown & $76-1-7$ \\
\hline 1977 & C1ty of Newport & BLOATING PIERS & Newport Harbor/Newport & $77-9-4$ \\
\hline 1977 & Qu1dnesqef Propert1e日 & PILL MARSH & T1bbets Creek/North K1ngstown & $77-5-19$ \\
\hline 1977 & Orzach & RIP RAP & Block Island Sound/Charlestown & $77-12-4$ \\
\hline
\end{tabular}


TABLE $10\left(\operatorname{Con}^{\prime} t\right)$

YEAR

MAYRE

1977

1977

1978

1978

1978

1979

$$
1979
$$

1979

1980

$\mathscr{2}$

1980

1980

1980

1980

1980

\section{Krohe}

Diglulto

Cott.

Burd1ck

Barnack

Vare

$$
\text { Montaqu119 }
$$

W1111 amg

Ventura

Behneke

Ray Cot Plber

Montalta ${ }^{3}$

Boint Judith Shellifioh

Glanote1 4

\section{PROJECT TYPE}

RIP RAP ${ }^{1}$

RIP RAP

SFDU/ISDS ${ }^{7}$

ISDS

CONCRETE BDAT SHED

SFDU/ISDS

SFDU/ISDS

Pfl1nge

$4^{\prime} \times 20$ ' Ploating dock

$w / 24 \times 20$ sections

SFDU/ISDS

Retalning wall and fill in

RIP RAP

PIER, FLOATS, PILES

WALL, BACKEILL, BELOW MHW

\section{WATERBODY/COMUNITY}

Block IBland Sound/Charlestown

FILE NO.

77-12-5

Block Island Sound/Charlestown

$77-12-6$

Block Island Sound/Charlestown

$78-4-11$

Ninlgret Pond/Charlestown

$78-9-2$

Ninigret Pond/Charlestown

$78-11-10$

Pettaquamscuft RIver/Narragangett

79-2-1

Block IBland Sound/Charlesțown

79-7-7

Potter Pond/South Kingstown

78-12-4

Pawtuxet Cove/Warwick

79-7-19

Green H111 Bond/South K1ngstown

$79-7-10$

Warren RAver/Warren

78-1-1

WInnapaug Pond/Westerly

$79-4-19$

Sakonnet RIver/Portsmouth

79-8-11

Ninigret Pond/Charlestown 
TABLE $10\left(\operatorname{Con}^{\prime} t\right)$

YEAR

1980

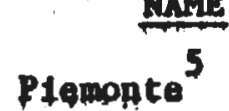

1980
PRQJECT TYPE

\section{RETAINING WALL IN} PILLED MARSH

PILL BELOW MHW

\section{WATERBODY/COMMUNTY}

Boster Pond/South Kingstown

Patter Pond/South KIngstown
BILE NO.

$80-3-11$

79-5-31

NOTES: (1) Project on Barffer Beach

(2) Plle pot located

(3) Complefed w/a Aseent: ordered to restore $3 / 11 / 80$, No compliance $11 / 12 / 80$

(4) Completed w/o Assent: Ordered to restore 3/11/80. No compliance 11/12/80

(5) Diacharged with prejudice; Ordẹr to Restore after State Propertles Committee fefused to legallze it by lease agreement. 
to the case that was denfed. No objection was voiced to the project that recelved approval. The Council's findings in the denial that "It further came to light (at the public hearing September 26, 1979) during the testimony that certain docks and plers have on varlous occastons been placed In the within area wthout the benefit of a permit from this Council," 81 may be totally irrelevant to the decision, yet appears to be a factor in arriving at the dectsion to deny. 82

G. Conclusion on RICRMP Implementation Based on Case Load Analysis.

\section{I. "LandsIde" Implementatton: Progran Impact.}

The review of the history of the Rhode Island Coastal Resources Management Act of 1971 clearly shows that a mafor reason the legislathon fatled to pass in 1970 was the provision for state authorfty inland to 200 feet or to elevation of 20 feet mean high water, whichever is greater. That legislation was rewritten to exclude the inland boundary by keeplng the boundary at Mif where the state had clear histortcal Jurlsdiction. 83 It then included the spectific activities or Iand uses and phystographical features.

When the state drafted the RICRMP, the 200-foot inland boundary was devised ta demonstrate to OCAM that the Rhode Island Program was not simply a "wet area" program, but that tt could also regulate land usea that impact on the coastal enviroment. The 200-foot Iine was chosed becanse it can be demonstrated that activities within that zone con impact of coastal waters and physlographical features. For inatance, Sect1or 310.4-IA of the RICRIP finds that nitrate from septic systems have been found to travel as much as 200 Inear feet through sotl below the root zone, and that altrate appears to be something 
of a concern because it contributes to phytoplankton growth and eutrophication.

What the RICRMP did in 1978, therefore, was to administratively capture for the state a portion of the land that the General Assembly refused to grant Iegal authority for elght years earlier. It could be argued by the cynics that the move was made only to capture federal program dollars under Section 305 (CZMA). It could also be argued that it was done to control land use, and, thereby regulate Impacts on the shoreline, physlographical features and coastal water quality, and to insure compatible use. This argument is presently ut1lized, and not whout good reason. But, if it is to be wholeheartedly accepted, one would be expected to ask what the outcome is or how, in fact, does regulation of this zone occur? This question is poignant because land management in Rhode Island has repeatedly falled to gatn acceptance in the Rhode Island General Assembly.

Erow 1969 to September, 1979, the CRMC applfcation rate for stogle-fandly dweIIIngs. (SFDU) and septle systems (ISDS) was 16 per84

cent. This rate increases when the perfod is shortened to 1975 to September, 1979, when it then measured at 20 percent. 85 And, when measured from May, 1978, to September, 1979, (a perlod of 16 months after Section 306 Approval), the rate swells to 38 percent of all applicationx. 86 From December, 1979, to October, 1980, 119 of 216 Notices frvolved stogle-family dreIIIngs and/or ISDS or accessory structures, for a cotal of 55 percent of the case load. 87 And, durfong the period July. 1979, through August, 1980, 53 percent of the Letters of No Objection have beex for activites involving single-family dwellings and/or ISDS or accessory structures. 88 
There is no question that local zoning dictates the land-use patterns. Therefore, if an Individual proposes a land activity that Is compatible with the local zoning requirements, the CRMC Assent is almost assuredly guaranteed, except in spectal cases directly on a phystographtcal feature, and even then, denial is not an expected outcome. In these typical, nonspectaI cases, applicants for singlefamily dwellings, septic systems, porches, garages, decks, butlding addftlons, major and minor repatrs, patios, greenhouses, vegetable gardens, etc., are assured that if they (within 200 feet of a coastal physiographical feature) subut plans, have Iocal approvals, write a check for $\$ 35.00$, and are willing to wait out a 30-day Notice perfod, watt the necessary 30 to 75 days (in instances of most uncontested cases), and an Indefintte perfod of time, more than 75 days in contested cases, they will recelve an Assent which typically has the foIIowlag stipulations: 89

(I) A vegetative buffer zone (typically 50 feet; but varles acconding to site conditefons) shall be matntatned;

(2) A Ifne of stacked hay bales shall be installed at the seaward edge of the construction area prior to construction;

(3) All disturbed areas shall be revegetated lmediately after grading is completed and that all grading shall proceed as soon as possible after construction is complete;

(4) AII excess debrts shall be disposed of at a sultable upland doposal ares:

(5) All fill (ff it is used) shall be clean and free of matter, that wII cause polIution of the water of the state; and 
(6) The dwelling shall be elevated to or above the base flood elevation established by the Flood Insurance Rate Maps, and in accordance with the provisions of the Rhode Island State Building Code Rules and Regulations for Construction in Flood Hazard Areas.

One pIcture obtatned from the data is that the RICRMP and the CRMC Is clearly involved in the land side of the coastal zone, trying to regulate residential development, and Ifghtly so. The procedures of this towolvement are very predictable, and produce results that are: (I) orly consistent with the Iocal Iand use predetermination; and (2) only fnvolve stee Impact mitfgation.

2. Programmattc Deviations and Inconsistenctes.

Another conclustor presented by the case load analysis is that the Crac has developed a pattern of issuing assents that appear to be inconststent with the RICRM poIfctes and regulations. These apparent inconstotencles are not confined to any particular profect type or locatton; they affect water bodfes and phystographtcal features as well as varfous project types. Others are discussed in Section $F$. a. Central Barrler Beach: Geograph1c Area of Particular Concern.

Bvents on Central Barrfer Beach, Charlestown, reflect several of the problems faced by the Rhode Island Coastal Program. These fnelude the programmattc inconststency fssue, espectally, but also potnt to the supremacy of Iocal dectsfor making and the problew of the cauc going last in permit schedulfng. The culmination of separate uncoordinated dectslons on Central Beach has effectively 
strlpped the management program of its power to manage this barrier.

In late 1979, a letter of No Objection was sent to the new property owners of several parcels of land on the Barfler granting permfsefon to implement "repairs to an existing Ifp rap wall... (with) no materlal to be placed below MWW." 90 The letter acknowledged that there was a definite potential for erosion to be caused by the rip rap. If offered some engineering advice stating that said advice. mag "matntain proper wall stability (and that) dune grass vegetation shorId be established uland of the vall." 91 ThIs language is at best permisaive.

The RICRMP Section I40.0-2-C.3 specifically prohibits the use of structural erosion controls on Central Beach, and others, unless there is a demonstrat Ion "by probative evidence lack of avaflable sedtment for such nonstructural methods" or vegetation, fenclng, and sand bags. The gtaff engineer reported on this case prior to the Isaunce of the letter that "Ifp rap protection in varlous state of distepaft and completeness is found along the total length of the appIfeant's property (and) the presence of several natural (assumed) boulders whtch form a type of incomplete natural barrier." ${ }^{92}$ The englneer went on to report that "600 tons of Ifp rap would be used for the project (and that) It is unclear as to (whether) an exdsting incomplete Elp rap cover constitutes nonstructural protection according to CRMc regulations." 93 No effort was made to require the appIfcant to meet the evidentiary burdens. 
More than a year later, the staff engineer reported that "This seawall was granted as a 'repair,' but is essentially new construcHon. Various stipulations on the repair have not been met." 94 He reported that the wall was constructed vertlcally instead of on a 2:I sIope as permitted by the letter. No dune vegetation was established. Unauthorized fiII was utllized, and the location of the wall was seaward of the dune, rather than shoreward as authorlzed. The report continued: "It is uncertain as to what action the CRMC intends to prove with regard to the above violation." 96 The memo reporting this information was filed with the orfignal Letter of No Obfectlox. The staff blologist, whlle investigating another profect proposal in the area, reported that "the extensive retaining wall along this shore was installed approximately $1 \frac{1}{2}-2$ years ago, following Issuance of a "Letter of No Object1on" by the CRMC. Portlons of this wall further to the west extend below the MHW mark and have a.lI but elfminated sections of the beach through erosion." 97 It is this latter phenomena that the regulattons of Section 140.0-2 mere destgned to prevent.

The problems on CentraI Barrler Beach are not confined to the If rap. As the Ifp rap saga unfolded, the property owners resold the individual house lots, which lncluded at least eight separate properties with single-famfly drelifings and ISDS, (Table 12). The new property owers, in accordance with the provisions of the purchase agreement, commenced to rehabilitate the dwellings. Work proceeded until halted by a CRMC Cease and Desist Order. The local 
building inspector had issued the local permits which allowed work to proceed without the necessary state approval. This is an excellent example of the confusion that results in this dual jurisdiction area where, by virtue of the State's Coastal Management Act, the state has primary furlsdiction. In a letter to the CRMC, the local ButIding Inspector advanced the following defense of his actions: "I did not realize that a person had to make application to the CRMC to protect and improve his property on a developed barrier beach." 98 More than just protection and improvement, these dwellings arguably underwent substantlal rehabflitatlor. That 1s, the work constituted a cost more than 50 percent of the fatr-market value of the ortginal structure. In such cases, the RICRMP Section 130.0-2 requires that the structures be elevated an addittonal 6 feet above the flood elevatlon established by the National Flood Insurance Program. By avoldIng the substantial rehabilitation criteria, the additional elevaHox requirements were side-stepped.

The butIding inspector continued: "The tax revenues or these propertles will double in value, too, giving Charlestown a more aesthetically pleasting area, a more healthy leaching system, as well as contributing to the tax revenue appreclated by the town." 99 This may not be first-rate wrteing, but it certainly convegs the idea that the town's interest in. these propertles resides in their contefbution to the tax base. For a communtty with few resources and a ahatios tar base, the retention of control over these properties to a primary conceru, regardless of what the state coastal management program says. The admintstration of the management program, . 
in a manner inconsistent with adopted prohibition and stringent tests, aids and abets this form of localism.

The problems with a state program that cuts across tradithonal furfsdictional boundaries was seen in Florida three years ago. Governor Rubin Askew declared in 1978 that the Coastal Program "will give lasting consistency and direction to the landmark laws we have enacted over this decade of enviromental reform. However, a spokesman for one of Florfda's largest developers, a forwer goverment admintstrator of the Florida Land and Water Hanagement Act; declared the Coastal Program to be "very fnconsistent (and) dupllcative... We don't need any more regulation in the coastal zone, he sald, because we have enough regulat1on now."101 A Lobbyise for the Flortda County Commissioners stated that "The subject is one that goes so directly to local control of local Iand development that we simply aren't prepared to talk about what's in the Iong-range Interests of the state at this time." 102

Writing ort the Coastal Zone Program nationally, Daniel R. Mandelker states that "the record is not altogether encouraging. An amblgunus statute, indecistve administration by the national coastal office, and increasing polftical resistence have produced a mixed record." 103 To this, we might add Indecisive admintstration at the state level. Sara Chasts has been espectally critlcal from her posttfor in IRDC. She has accused the national program of not fulfilling tts promise because it is not protecting valuable resources, and feels that it wII become a "paper planning process" that states 
go through "to qualify for federal funds, with minimal changes in the way human activities affecting the coast are conducted."105

b. Conservation/Low Intensity Use Coastal Waters.

Anotber sltuation where the CRMC has obviously acted in a continuaIIy inconsistent manner with the adopted policies and regulations of the RICRMP affects the Conservation/Low Intensity Use tidal waters and coastal ponds. Section 110.0-20.1a of the Program permits stormater rumoff, deposition of ftil, dredgtng, and structures in navigable waters "only upon demonstration that a bona fide benefit to the public welfare will result and further that no reasonable alternative exists.

One such tidal area, designated as a conservation/low intensity use area, is the Barrington River. Since 1979, the CRMC has issued assents for at least 11 projects in the River (Table II). Seven of these can be classified as new structures, one of which Irvolved filling below mean high water, an area. of approrfmately 570 square feet, rather than require the appl1cant to uttilze another approach to repair a deterforating manrade structure. There is no evidence on file or in the transcrlpts explatning why these programmatic deviations have occurred. $\therefore$

If ow accepts the argument that the state went through an extenstre plaming and public particlpatlon/education process uetIrzing $\$ 1.5$ million in federal funds and $\$ 500,000$ in state funde to produce an acceptable management program, then one 
could logically assume that the policies and regulations set forth in 110.0-2-D-1a of the Management Plan reflected a desired public goal for conservation/low intensity use waterbodies. Devtation from this, that is, the granting of spectal exceptions should occur only when the evidentiary burdens of proof were met. The evidence does not reflect such measured decision-making.

The case of granting an Assent for an aquaculture profect In Quifksand. Pond, Iftele Compton, Is agatn illustrative of this disregard for the requirements of Section 110.0-2-D-1a. It also may reflect a cause of the devlation: the ignorance of the requirement. Quicksand Pond is a conservation/Iow fntengity use coastal pond designated by the RICRMP as an Area for Preservation and Restoration. It is an Audubor Society Natural Area. The State Gufde Plan classifies all the land surrounding the pond in anen-space category, and the town has the land soned for residential Iow intensity development.

This project received an intense obfection from the Rhode Island Audubon Soctety as well as from some local property owners. The Audubor Soctety obfected on several grounds which ineluded the sufficiency of data supplled by the applicant. 107 The larger Isoues clted were much more ta the point of having a coastal management program and 1 ving with it to a consistent manner. The Audubor Soctety Brecutive Dlrector objected to "allowing, espectally through the questlonable device of mullipIe 'experimental' permts, the beginaings of commerctal explot- 
TABLE II

PARTIAL IIST OF ASSENTS FOR

SIRUCIURES IN BARRINGTON RIVER

SINCE 1979

ASSENT

NO

(Approved

$3 / 24 / 81$ )

Hartley

MatinelIa

Geomente

8-BR-81

Cambria

165-BR-80

Shepperton

ISI $-\mathrm{BR}-80$

Bartor

$30-B R-80$

Barris

52-BR-80 Barrington

T.C.

FIoating dock

Plers, floats

Pile rimber Pler

156-BR-79 Besmint

Reanint

4/24/81) 1ngs. figuration

$3^{\circ} \times 190^{\circ}$ p1le macely $570 \mathrm{ft} .^{2}$

E111 below MEW) extension

Ramp, pler, float

Plex, float

PLer, fIoat

19-BR-80 Asbworth
Rebulld pler, dock Eloats, ramp, p11-

$46^{\circ}$

west

Rearrange dock con-

$105^{*}$

east revetment; $16^{\circ}$ pler extension (approxi-

Ptle and timber pier

$39^{\prime}$

east

$60^{\prime}$

west

$80^{*}$

east

$54^{\prime}$

vest

$69^{\circ}$

west

$\therefore$
30 ft. extension to pile and timber pler

Preparatior Date: 4/14/81 
tation in any of the few remaining natural and unspolled brackIsh ponds in Rhode Island (whtch) does not seem to us to be a wtse Interpretation of the Counctl's larger mandate." 108

The proposal appeared to be couststent with the CounctI's prfortties for uses in conservation/low intenstey use water bodles, at Ieast in the sense aquaculture is not cited as elther a high or Iow priority use. 109 Eowerer, as it Involves the placenont of aquaculture rafts (structures) in navigable waters, the Inene ver pever addreneed.

C. Coape Guard Barrier Beach: Geographic Ares of Particular Concern.

Coast Guard Barrler Beach is classifled by the RICRaP, Sect5ox 130.0-2A, as a dereloped barrler beach. It is also deg1gneted for conservation uses by the prforfties for Jse Maps in the programa These goals conflict in that one allows reaidential deveIopwent and the other 1mpIles, at least, no development. S1nce the RICRMP was adopted, the CRMC has recelved efght appifcations for development on this barrfer, five of which have been for new conserwetiox (four new stogle-family dwellings with ISDS and one baxp).

The firat application for an STDU/ISDS recelved by the Couneft oceurred in Inte 1978, and recetred an assent in November of that yecr. The assent stipulated that onls the minfmum ares for combruction be cleared and that aII areas distwobed during conatruction be restored through the reestabilshment of beach grass. 
These stipulations were in accordance with the staff blologist's recommendations. The file contains no evidence that the RICRMP programmatic requirements were considered altbough the comment from the Rhode Island Statewide PIanntog Program states: "This proposal ts for a. howe on a barrier beach, therefore, all CounefI barrler beach polfcles and regulations apply."III

The reports in this ifle do not speciflcally state that the PIw résidence was proposed to be located on a sand dune. Horr ever, andysis of the site plan and compartson to information on aubsequent cases, Indlcate that the dweIIIng was proposed on and dunes as defined by SectIon I20.2B of the RICaMP. Section 120.0-2D-1C of the RICRMP states: 112

Construction or alteratlor of sand dures shall be probiplted, except where assoclated with an approved reatoration or stabllization project or where demonstrated neceseary to promote or protect the publle welfare, and then ouly when no signtficant damage to the coastal enFiroment will result. In soch cases, the Council may allow temporary alterations where adequate assurance is provided that the altered aren will be returned, restored and stabllized to approxtmate 1ts patural state an it extated prlor to the alterattor.

And Section I30.0-2AI spectfically states that "Constructlox, Iestoration and/or aubsantlal Improvement of structures on the beach face or dures shall be probtbited."113 The assent clearly appears to be inconntseent with tor sections of the adopted management proex.

- L your after the assent was Issued, the applicant PIumb was contacted by the Caruc because conditlons at the dvelling gite were found on November 7, 1979, to Indfeste that restoration had not 
114

occurred as stipulated. And, again, another year later, it was reported that the conditfons of the assent "have not been adhered to, and that activity beyond the extent of the assent has taken place.

Less than one jear after Plumb recelved an assent, the CRuc put out to Public Notice three proposals for single-famils dweIIIngs and ISDS, bringing to four, the number of dwellings to be conteructed within a stretch of 1500 feet of barrier beach. Ther were approved or August 26, 1980, after a Iengthy bearing procese.

Ox Auguet 28, 1980, te was reported that the Director of the Bhode Island Department of Environmental Management wrote to the etate's Attorney General requesting it be determined whether the canc violated lts orm polleg. The vote to approve the applfexton we noted by the press to be marked by two Councli mambars, who had afgmed a subcomattee recommeodation to deny, reversIng thetr stance and potting for the petitlor. One of the changed votes was cast by the Chatrman who Iater wrote to the press that "the Counct cannot Ignore the Superior Court ruling that provides owpers of developed berrier beaches a Ifght to utilize their properts."188 (It to important to observe that ut1lizat1on is not definad as conotruction of alngle-famety dwellinge wth ISDS.) a

$\therefore$ The Providance Jownal Compeny, in an editortal, declared thet the action of the Counctl was hot only hard to understand, but Incomprehenatbe!"119 The Dar's former chtef legal counsel 
wrote to The Providence Journal that the CRMC's action not only ignored its own polictes, but it Ignored recent case law which rejected the contention that applications must elther be approved or the property purchased. 120 The Attorney General was reported as saying he belleved "that prlor Superfor Court decla1one do not so severely restrict regulation of bullding on barrier beaches. "I2I He concluded that "fudfclal review of the CRMC approvals will act to clarify the regulattons conceraing development on barrler beaches, and will act to clarify Rhode Island law regarding the public's interest in preserving our shoreline."122 These cases are peoding court action.

It should be noted that Coast Guard Barrler Beach has been under active conslderation by the U.S. Department of the Interior, Rntional Park Service for IncIusion in the Barrter Islands Na123 tfonal Park. Thls program has recetved stroag support from the cinuc. 124

Subsequent to the CounctI's action to approve the three drelIIngs and ISDS' $\mathrm{a}$, there have beex appllcatfons for a barn, Iaodscaping, and two singIe-family drelling additions on this barter beach. 125 The two dwelling additlons were started without a couc assent, and one wes balted by a Cease an Desist. The reaff bfologtet reported thet the project appeared to be in dircet conflfet with the RICive and that restoration of the wea would be very difficult. Ihe Counc1l approved the profect on Aprt1 14, 1981. The barn and landscaping are pending as of II. I98I. The otber additfor wes substantlally completed by 
TABLE 12

PROJECIS ON BARRIER BEACES BEFORE

GRMC FOR FULC 30-DAY NOTICE

DECAMBER 1979 TO APRII 1981

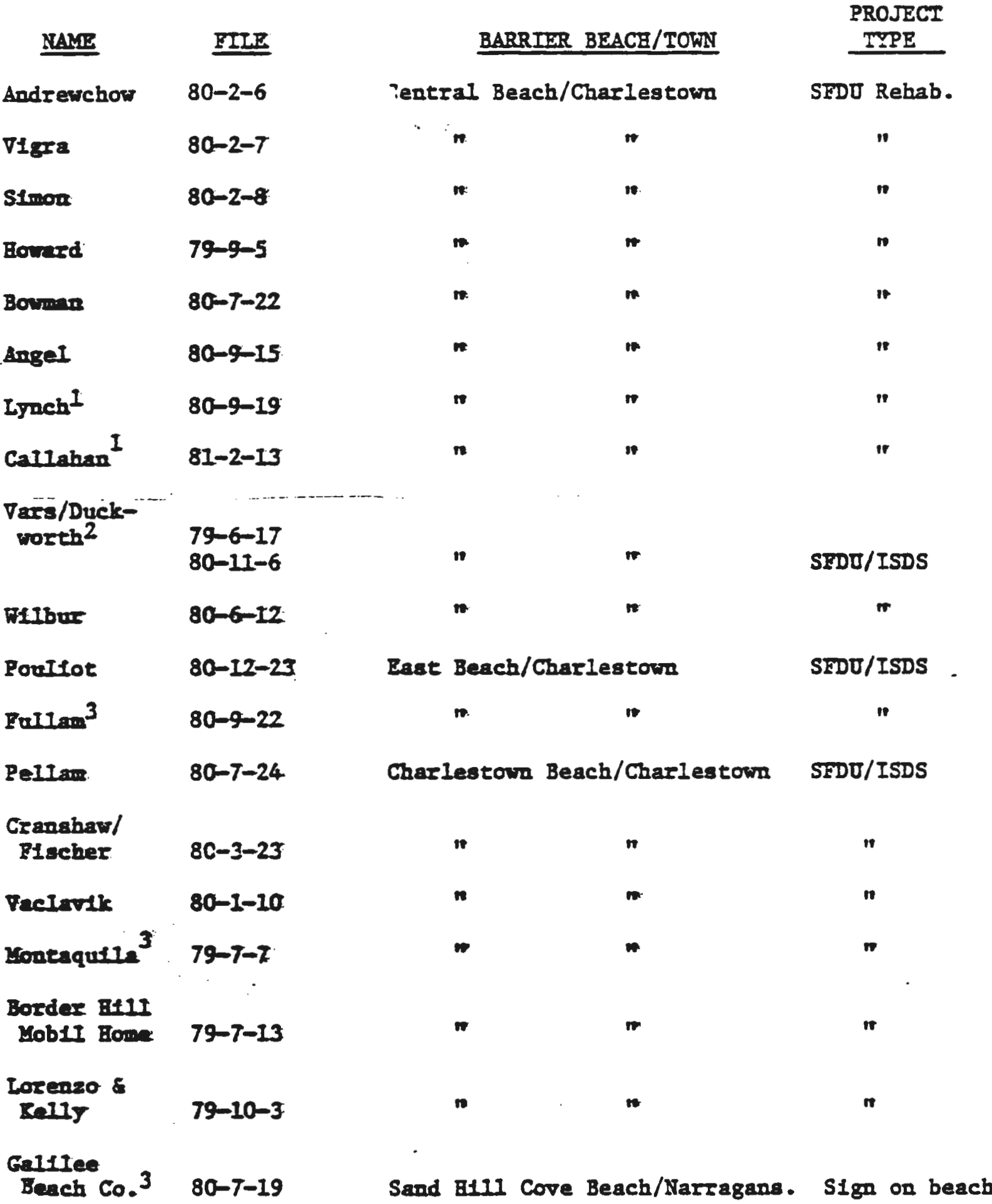


TABLE 12 (COn't)

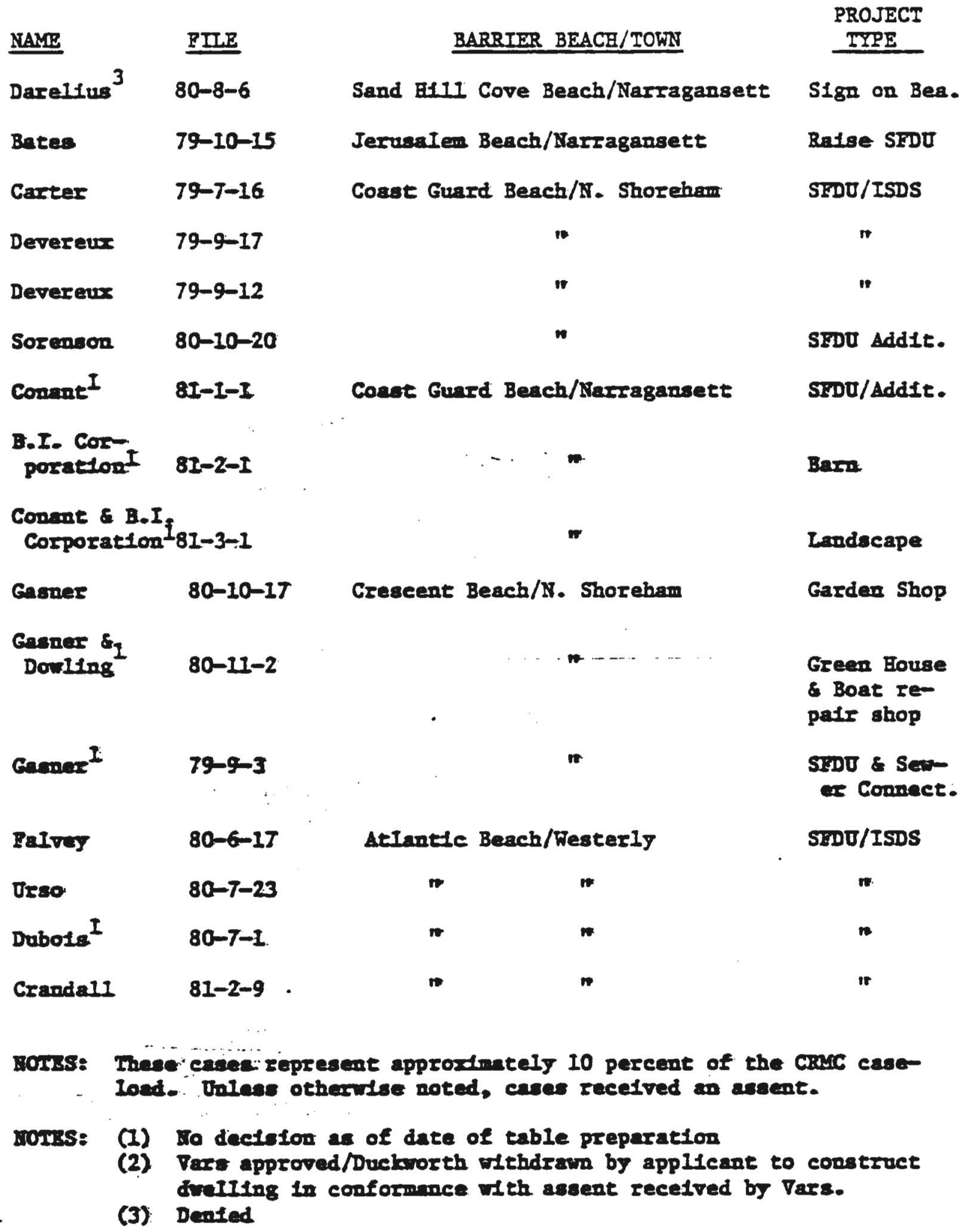

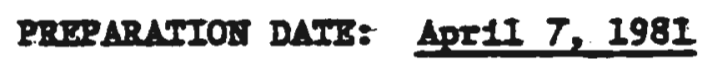


July, 1980, without an Assent from the state, although a local 127

butlding permit had been Issued.

3. Arees for Preservation and Restoration: Case Study of the Petraquamscutt River Programmatic Fallure.

The Pettaquamscutt, or Narrow Rfver, has been Identifled by OCan as an area where water qualley mo be deterforlating and it (m......

Is one of three "gigntficant problems whtch the state must work 128

to resolve." The Blver is clasalfied by the RICBop as an area for Presarvation and Restoration. Its weer is deslgnated for mitiple use recreation. The GRuc ackowledged the aeed for problem resalution in the watershed, when on Jume 26, 1980, the Council formed a subcomulttae on the Narrow River Watershed, that "by coordinating the Information avallable to this area and acting as a catalyet between the towns, state agencles and concerned cit1zens, cax posetbly provlde the necessary leglslattive authortty to correct edsting, condittons or the watershed. "I29 The councli prides tteatf on its role as a catalyat.

The Pettaquanscutt RIver watershed makes for a particularly inearesting case study because it demonstrates amply the effect of the Croc's approach to resource mangement, and the linfted abIIIty of the Councll to affect Indside activity because of the predoutnate role retalned by local goverment. It is a sigatficant resource, which Is affected by negative att1tudes, three of whlch have been tdentified in a draft interoffice memo to the Counc1l. The draft, prepared In June, 1980, has never been discussed by the Counc1l at t28 regular forums. 
The most negative expression seems to be along the line that nothing can be done about the rfver and the watershed because the damage has already been done, and the fate of the resources was sealed by past development and zoning. A second negative attitude which argued agatnst action to govern the watershed differentiy from current practlce, is best expressed by the assumption that the Flver has always been the way it is now. That 19 to say that the fenrs of the preservationtsts and their supporters are substantaIIJ unfounded. The thtrd most commonIy heId positton appears to crolve out of the inherent contradiction expressed in the first tro dimnexfeaIly opposed beIfefs. That 1s, what can we do?

The RICRMP has established in Section 110.0-202 apectal conofderation for waltple use recreatlou estuaries, such as the Pettaquamscute River. It permits Industrial development, deposition of ftII. dischagge of domeste, muletpal and Industrial sewage, extwatve gradtng or excavat ox, storage or transport of hazardous materials, and any activity discuptive or recrentfonal use "only upon. dewnstration that a bons fide berefit to the public welfare will reault and, further, thet no rensonable alternative ex1sts." 132 Section 310.0-2A of the BICRMP defines sewage broadIy and declares thet:

Becene zwoff may tnclude substances which may be infurtous to public henith or to antmal and/or plme Iffe, for the purposes of the Cosstel Besources rimagement Program, 'sewage' shall be further defined is foluding alIt and other particulates introduced into, and/or artifictal increases or decreases above or below ambient freshrater inflow Into t1dal and InT33 tertidal waters, coastal ponds, and coastal wetlands. 
It is also defined to include "every substance which could infurfously affect the natural and healthy propagation, growth or development of any animal and/or plant Iffe tn the water of the state, or the nowrishment of the same." 134 Logically, thls Iangoage carries with te restrictions on the permitting of stormwater outfails in the Pettaquamscutt River, because storwwater rumoff typlcally contalos hydrocarbons, chemical fertilizers, chanteal peatlctes and herblcides, and colfform bacterta.

The tesue of outfalls In the Ifver was apparent in May, 1976, when the town of South Rfngstown sought approval to Install a atowil drain outfall toto the Iiver. The project proposal recelved afgeficant comment regarding 1ts potential fmpacts from the Statewde Planning Program, which were evldently Ignored. 135 There were also comments and recommendations from the staff R1sh and WfIdIffe Blologist, which were simflariy Ignored according to the

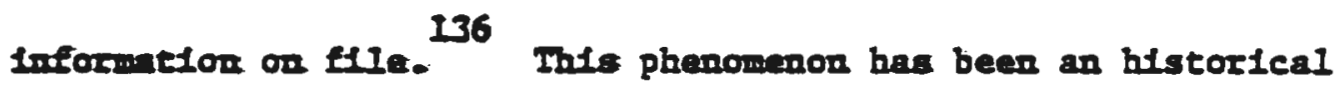
characterlatic of the Program (Table 14, Table 15). Sloce 1976, the CRec has 1saued approvals for four additlonal outfalls. One of then in 1979 recelved simflar comments expressing simflar concerns as in 1976.137

There hrve also been two approvals for the 1nstallation of the

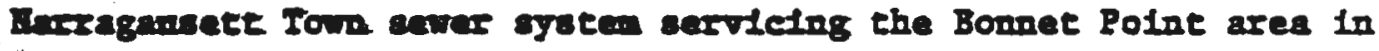
the coastal drainge basin and a portion of the eastern section of the Peteagumincute Hatershed. The PICRMP, Sect1on 310.0-2C2, requifes the demonstration "By rellable and probative evidence that 
coastal resources are capable of supporting the proposed activity Including the potentlal impacts and/or effects resulting from... cumulative 1mpacts....changes to cont1guous land use...secondary Impacts resulting from additfonal development stimulated by new pubIle factIftes and the need and demand for the proposed action. 138 One of these projects was a $16^{\prime \prime}$ force matn and the record indicates that the staff recommended the implementation of short-term site impact iftigation procedures and noted that the only way the CBMC coutd Influence the impact of the antictpated development spinnting aff the sewer profect would be on a case-by-case basts unlese the CommetI chose to do otherwlse. I39 The dectalon to fnatall the sewces we a loenl one made years ago and the Councll Indlcated no deatre to pick up the refos in 1980.

Rellance od only site Impact mltigation procedures has prover chancy at best, as in the case of the pumping station in the Bonnet Pofnt regtor. It was stated on the record that: "A fleld check of the profect stte or July IT, 1980, revenled work was proceeding in Fiolation of the Cease and Desist Order and that sediment laden water was being dischnrged directis Into Wesquage Pond (an Area for Preaervaton and Restoration and a Conservation Low Intensity Dse Cosstal Pond where such discharges are strlctis prohtb1ted). ThIs

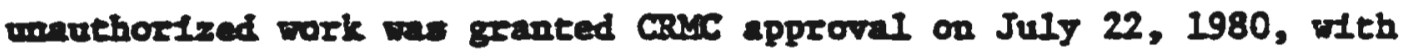
the sefpulatione of the bfologlot's report dated JulY 17, 1980. 140 Server in 1975 reported in Marlne Techntcal Paper No. 141 that the Iarrov Rfver (Pettaquamscutt) contatns a wide varlety of aquatle organtoms. Bf seated that the Bfier "may be one of the most vulner- 
of Rhode Island estuarfes. Since it extends in a long, narrow band for nearly six miles, and is bordered by a steep and largely nonporous watershed on both sides, the potential is high for contaminated runoff, leechate, and other pollutants to enter the Ifver system." Seavey recomended that no additlonal pipes from ans source be permitted to discharge into the fiver and that there should be "a program to dispose of sewage and effluent outside of the fmmedlate watershed" for future extensive development. The following year, the PIan for the Narrow Rtver Watershed supported Senvey's concluetons "The discharge of rumoff from stormater drafinge gyotems directly into tidal wetlands...that have been alIowad In the past ofII, If continued over time, result in the envirommental loss of an tovaluable estuarine resource." 142 The plan noted that "observations by residents indicate that the qualIty of the water 1 a decreasing." 143 No concrete data is provided. in this discussion in the plan, but septlc syatems discharging through atoze dratns and into groundwater, urban runotf carrytng autonotlve wates, nutrients, sediments, organic wastes, and fecal baterta, and sedfment discharge from cleared upland areas were all cited as factors that can and ing be adversely impacting the estuary's. weter qual1ty. 144 Addftlonal studies and reports on the Rfver's Water Quality have supported the hypothes1s that the watec quilty is betng adversely tmpacted by developwent. Notably, - report prepared by. SIeburth. Hater Quality of the Narrow River, 1959-1979, which presents data ox "htgh counts" of collform and argues that Merrow River is significantly polluted during the sumnex monchs." 145 In 1980, a swrey of sectlons of the Narsow River Viatershed by RIPE, Inc. (Rhode Island Profects of the Eaviroment), 
reported finding dwellings with1n 350 feet of the rlver that were discharging greywater onto lawns, older systems suspected of belng constructed of metal, and alledged sewge tle-ins with storm 146

If 1979, the RIver was temporartiy closed to shellfishing because of the high coliform readings reported by : leburth. Bowever, In September, 1979, a shoreline survey and shore sampling of the Rfver by DEM, DIVIsion of Nater Resources, reported colfform data thet contradicted Sieburth"s findings, and concluded that "unless noce information is provided to the contrary, these do not appear enough evidence to warrant continued emergency cloawre of this area to shelIflobing. 147

SIfghtly more than one year later, it was reported by the DEM Diviston of Water Besources, In a statement to the Narragansett Times, Diat: the past sumer's low pollution levels "colncide with the lack of rainfall in the area....(and) that the mafor problen in this area is rmoff related."I48

Since 1979, there have been requests from the town of South KIngstown and the Federated Rhode Island Sportsmen's Club, Inc., urgIng the Gauc to not approve any further requests for assents along the Barrow Rlver and coastal pouds because of water quelley probIne in thooe weterbodies. 149

Stutlar concerns have been expreseed by the Narragansett Conservetion Commisalon and the Hattaturet Improvement Associatlon, al- 
though the Mettatuxet group apparentig has not taken as strong a position as others. 150 The "Moratortum" concept has been cited by the Statewide Planning Program. 151 The Federated Rhode Island Sporesmen's Club; Inc., has also argued that "new septlc systems shoutd have a mintmm setback of 300' from the r17er." 152

The N. rrow River Watershed Plan presented a number of cogent arguments for breaktng from past development trends in the watershed. Some of these are:

- Dithout adequate control of wetershed development, aesthetic distnetion and diveratty and the scente, recreactonal, and comantty benefits derfing from them risk betog destroyed. 153

- If clustered housing or a simtlar pattern is not encouraged as an alternatfie type of development wthin the ratershed, the opportmity to preserve natwral aesthette resources and to enhroce the aesthetic quality of communtty Iffe may be lost. 154

- Dithis the wetershed, a patterr of severe and moderate Ifmttatlons for communtey development based on solI and siope characteristics emarges.

- Posatb1l1ty of realdentlal development in these areas poses potental problem in terms of Individual development costs, pubIte arvice provtaton costs, and other enviromental costs. 155

- Flood Bnzards along the Marror River may be oufflclent to cause conatierable damge... The exsting on-site septle system along the river wII washout....The continued development of the flood 
pla1n w1ll ultimatels result in public as well as private costs. 156

- The land omership pattern has the potential for conservatfon through Individual owner inftlative and large-scale development. 157

- Extension of public sewer service to the middle river communithes wil amellorate the reported problems of septic system pollution (but) the avatIability of service will make bigher denattle posstble (and) mag result in additional urban runaff or sedimentation problems.

- Bxisting land use controls to both concentrate communtty devel-

- opment in approprlate areas-in terms of physlcal sultabillty and service levels-and to mintinfe development in loaproprlate 159 areas are weak.

The Rorsow Rtver Preservation Assoctation (MRPA) bas argued in favor of the Gruc being more actively involved in the management of the Btver and Its wetershed. The Assoctation wrote in Febrary, 1980, requesting the Cruc:"change (Its) polfey for the future in such a way as to allow (the GRC) to consider a developwent as a whole," rather than procese applfcations individually. 160 stoce then, no mbdivfatous in the weterahed have been revlewed by the Counc11 (TobIe I3). The 1soue is meeh Iarger than simple reviewing develop neot as a whole; and while thl lasue has been addressed to the CoonetI prIor to the IPRA's request in 1980, notably In January of $\therefore \quad \cdots$ 
that year during the discussion of a proposal for a single-famtly dwelling with ISDS in the Upper River Watershed, and elsewhere in the state's coastal region, it is anclllary to the main 138 sues of how much authortty the CRMC has to regulate land use. It is also secondary to how witifig the Councll is to exerclse its authortites In a moner other than on a case-by-case basis. 
TABLE 13

PEITAQUANSCUIT RIVER DEVELOPMENT PROPOSALS SINCE 1977

\begin{tabular}{|c|c|c|c|c|c|}
\hline \multicolumn{4}{|c|}{ APPIICATION } & \multicolumn{2}{|l|}{ DESCRIP- } \\
\hline DATS & TOWR & No. & APPLICANT & IION & STATUS \\
\hline $2 / 22 / 77$ & Narzagangett & $77-2-4$ & $\begin{array}{l}\text { Towr of } \\
\text { Narragansett }\end{array}$ & $\begin{array}{l}\text { Storm Drain } \\
\text { Outfall }\end{array}$ & Assent \\
\hline $2 / 22 / 77$ & Narragansett & $77-2-5$ & $\begin{array}{l}\text { Town of } \\
\text { Narragansett }\end{array}$ & $\begin{array}{l}\text { Storm Drain } \\
\text { Outfall }\end{array}$ & Assent \\
\hline $2 / 22 / 77$ & Nerragansett & $77-2-6$ & $\begin{array}{l}\text { Town of } \\
\text { Barragansett }\end{array}$ & $\begin{array}{l}\text { Stom Dratn } \\
\text { Outfall }\end{array}$ & Assent \\
\hline $11 / 09 / 77$ & Rezeagansett & $77-11-5$ & I. Fortes & $\begin{array}{l}\text { D.T./ISDS } \\
\text { Ret. WaII }\end{array}$ & Assent \\
\hline $7 / 03 / 78$ & Karragansett & $78-6-11$ & S.J. LIndberg & D.D./ISDS & Assent \\
\hline $7 / 17 / 78$ & Narragansett & $78-7-4$ & $\begin{array}{l}\text { Estate of } \\
\text { L.J. Tartorta }\end{array}$ & D.U./ISDS & Pending \\
\hline $11 / 02 / 78$ & Rarragansett & $78-11-2$ & B. Rex Coman & D.D./ISDS & D1scharged \\
\hline $11 / 14 / 78$ & Narragansett & $\begin{array}{l}78-9-6 \\
\text { (reoub- } \\
\text { mteted } \\
79-1 I-1\end{array}$ & S.J. LIndberg & D.ర./ISDS & W1thdram \\
\hline $1 U / 14 / 78$ & Rarragansett & $78-10-11$ & A. Dlans: & $\begin{array}{l}\text { Remove sIIt } \\
\text { fIII; Ie- } \\
\text { place } 8 / \\
\text { gravel }\end{array}$ & DLscharged \\
\hline $2 / 08 / 79$ & So. Kingatown & $79-2-8$ & J. Bafler & D.U./ISDS & Assent \\
\hline $\begin{array}{l}2 / 08 / 79 \\
1 / 13 / 81\end{array}$ & Narragansett & $\begin{array}{l}79-2-2 \\
80-11-5\end{array}$ & $\begin{array}{l}\text { G. Varel } \\
\text { Botoln }\end{array}$ & D.U./ISDS & Asgent \\
\hline $2 / 08 / 79$ & Narraganett & $79-2-1$ & G. Vare & D.0./ISDS & Deased \\
\hline $2 \ln 2 / 79$ & So. Ingatour & $79-2-11$ & C. Iangung & D.D. add & Aseent \\
\hline $4 / 26 / 79$ & So. KIngatown & $79-4-21$ & C. Sharpe & $\begin{array}{l}\text { Carage: Apt. } \\
\text { \& ISDS }\end{array}$ & Aseent \\
\hline
\end{tabular}


TABLE 13 (Con't)

\begin{tabular}{|c|c|c|c|c|c|}
\hline $5 / 02 / 79$ & Narragansett & $79-5-1$ & E. Blinkhorn & $\begin{array}{c}\text { D.D./ISDS } \\
\text { Ploat }\end{array}$ & Asgent \\
\hline $7 / 10 / 79$ & So- Ringstown & $79-7-21$ & $\begin{array}{l}\text { Terre Mar } \\
\text { Realty }\end{array}$ & D.U./ISDS & Assent \\
\hline $8 / 28 / 79$ & So. Ringstown & $79-8-14$ & $\begin{array}{l}\text { Jay Ready- } \\
\text { hough }\end{array}$ & D.U./ISDS & Assent \\
\hline $8 / 28 / 79$ & Narragansett & $79-8-15$ & Town of Niers. & $\begin{array}{l}\text { Storm Drain } \\
\text { Ontefil }\end{array}$ & Assent \\
\hline $9 / 04 / 79$ & $\begin{array}{l}\text { So. Bngatown } \\
\text {.. }\end{array}$ & $79-08-18$ & $\begin{array}{l}\text { Barry Ready- } \\
\text { hough }\end{array}$ & $\begin{array}{l}\text { D.U./ISDS } \\
\text { D.D./ISDS }\end{array}$ & Assent \\
\hline $12 / 06 / 79$ & Rerregansett & $79-11-18$ & $\begin{array}{l}\text { S. J- Ifnd- } \\
\text { bers }\end{array}$ & D.U./ISDS & Withdrawn \\
\hline $9 / 28 / 79$ & Merzagansett & $79-09-33$ & W.I. Shes & D.U./ISDS & dssent \\
\hline $8 / 27 / 79$ & No. Ringatown & $79-9-1$ & E. Grove & D.U./ISDS & Agsent \\
\hline $1 / 04 / 80$ & No - Kengetown & $80-1-4$ & ผ. Brock & $\begin{array}{l}\text { D.U./ISDS } \\
\text { Sewer }\end{array}$ & Assent \\
\hline $2 / 04 / 80$ & Narragansett & $80-01-19$ & Town & $\begin{array}{l}\text { Punping } \\
\text { station }\end{array}$ & Assent \\
\hline $3 / I I / 80$ & Harragansett & $80-3-T$ & A. Tengyor & SFDU/ISDS & Assent \\
\hline $3 / 26 / 80$ & Rarraganaet & $80-3-18$ & Rmor & Bridge & Assent \\
\hline $4 / 07 / 80$ & 3o. Kingstorr & $80-3-26$ & L.D. Rortick & Floats & Assent \\
\hline $4 / 18 / 80$ & Rarragansett & $80-4-8$ & $\begin{array}{c}\text { Suffivan } 6 \\
\text { Earclert }\end{array}$ & SFDU/ISDS & Assent \\
\hline $12 / 31 / 80$ & Narraganaet & $80-12-24$ & Kenyon: & SFDU/ISDS (5) & Assent \\
\hline $12 / 01 / 80$ & Barragnnect & $80-12-3$ & S. Lindbers & SFDU/ISDS & Withdrawn \\
\hline $10 / 28 / 80$ & Inrragungete & $\begin{array}{c}80-9-13 \\
\therefore\end{array}$ & Tows. & $\begin{array}{c}16^{n} \text { Force } \\
\text { Kate }\end{array}$ & Assent \\
\hline$I / 28 / 8 I$ & ingregansett & $81-1-10$ & $\begin{array}{l}\text { Buvine } \mathrm{B}_{5-} \\
\text { tatean }\end{array}$ & SEDU/ISDS & Pending \\
\hline $3 / 09 / 8 I$ & Barzagansett & $81-3-2$ & ILE, Ine. & SLDU/ISDS & Pending \\
\hline
\end{tabular}


TABLE 14

1977 Cases with Major Copment/Objection fron 8tateulde Planning Program

\begin{tabular}{|c|c|c|c|c|}
\hline 0 & $\begin{array}{l}\text { Bordar H111 Fob1te Home } \\
\text { Crose, Andre (utthdrawn) }\end{array}$ & $76-12-9$ & $\begin{array}{l}\text { SEDU/ISDS on } \mathrm{BB} \\
\text { SEDU/ISDS on } \mathrm{BB}\end{array}$ & Charlestown \\
\hline LC & D'Antonto, Renata & $76-5-2$ & SEDU Addition OA BB & Sputh Kingatown \\
\hline MC & DeGul110, Vincept & $77-5-15$ & SPDU/ISDS Relocate & Cherlestown \\
\hline MC & Porteg, Joge & $77-11-5$ & SFDU/ISDS Flood Bleyettope & Nerragansett \\
\hline MC & Prtohman, Cant11e & $77-6-1$ & SFDU/ISDS & Weoterly \\
\hline $\mathbf{0}$ & Eroha, Johp & $76-9-13$ & SFDU/ISDS on BB & Charlestown \\
\hline $\mathbf{0}$ & Krohn, John & $76-9-12$ & SEDU/ISDS on BB & Charlestown \\
\hline $\mathbf{0}$ & Murfay, John & $77-5-12$ & SEDU/ISDS on BB & Charlestown \\
\hline $\mathbf{0}$ & Murray. Johq, & $77-6-10$ & SFDU/ISDS on $B B$ & Charleatown \\
\hline 9 & Hasse, VIncent & $77-10-1$ & Ma1nta1p Illegal fH1t In Maroh & Nafregansett \\
\hline Mo & Orzech, Walter & $77-5-16$ & SFDU/ISDS Relocate on BB & Charlestown \\
\hline a & Plectty, John & $76-8-6$ & SFDU/ISDS On BB & Charlestown \\
\hline MC & Bmith, Andrew & $77-8-7$ & SFDU/ISDS & Charlestown \\
\hline HC & South Kingetown & $76-3-15$ & Quffall on Narrow Rlver & South Kingstown \\
\hline
\end{tabular}




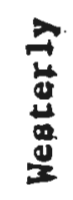

개

$\frac{1}{1}$

$\frac{1}{1}$

年

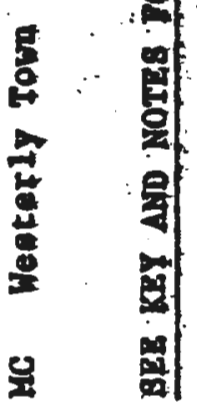


1977 Cages with Major B10log1cal and/or Eng1neer1ng Comment/Object1on

\begin{tabular}{|c|c|c|c|c|}
\hline ve & Derralra, Robert" & $77-3-4$ & SEDU/ISDS on BB & Weaterly \\
\hline MC & Reffett1, Margaret* & $77-6-11-11$ & SFDU/ISDS on BB & Char lestown \\
\hline MC & Freint, $T_{1}$ & $76-7-13$ & Pler, Ramp, Floate & Warw1ck \\
\hline $\mathbf{m}$ & Dr lohman, Can14to & $77-6-4$ & \$EDU/IBDS & Weaterly \\
\hline $\mathbf{0}$ & Lioar, RIchard & $77-9-8$ & R1p Bap Va11 & Narragapвett \\
\hline Co & McGraW, W117tam & $77-8-13$ & RAp Rep Walt & James town \\
\hline$M$ & Me110, Jease Lobert & $\begin{array}{l}77-10-7 \\
77-10-8\end{array}$ & 8FDU/ISD8 on Karmh & Little Copptop \\
\hline MC & Me11o, Jacenthot & $77-10-9$ & R1p Rap Weekapaug Bregchwny & Weaterly \\
\hline $\mathbf{0}$ & Wurrey, John & $77-6-10$ & SFDU/ISDS on BB & Charleatown \\
\hline $\mathbf{M C}$ & Narragangetf Toup" & $77-9-1$ & Outfall Near Publtc Beach & Narragangeft \\
\hline HC & Nas8a, VIncent & $77-10-1$ & Malataln 111 egal fill on Margh & Narragangett \\
\hline MC & Oxx, Gordont & $77-8-11$ & R1P Bap Wall & Jamestown \\
\hline $\mathbf{M C}$ & Plecfty, John & $76-8-6$ & SFDU/ISDS on BB & Charlestown \\
\hline MC & Restell1, Ed1tht & $77-9-10$ & R1p Rap Wa11 & Westerly \\
\hline MC & Saunderetowa $Y, C_{1}$ & $77-7-7$ & R1p Rap Wall & North Kingstown-- \\
\hline
\end{tabular}




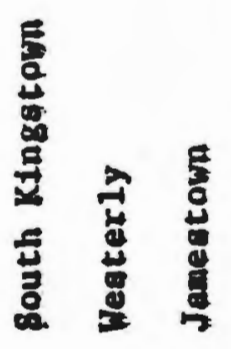

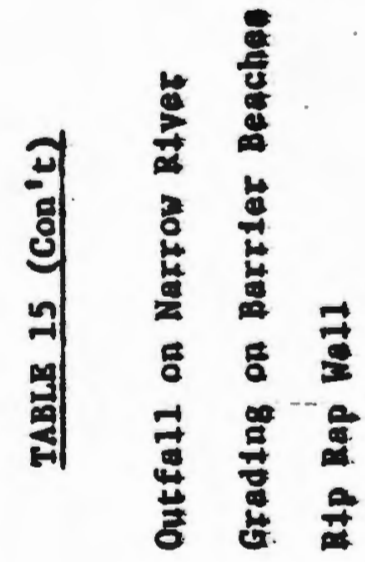

$\frac{1}{2} \underset{\frac{1}{1}}{\frac{1}{1}} \frac{1}{1}$

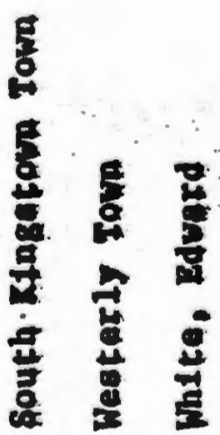

올 일 율 
TEI AND NOTES TO TABLES 14 AND 15

LEY: 0 - Objection and/or recommendation for denfal.

MC - Major substantive comment.

- Cases wth major substantive comment or objection and/or recoumendation for dental by Staff Blologists/Engineers, but with no Statewlde Planning Comment on file.

BB - Barrier Beach

The Statewlde Plaming Program offered mofor or substantive recommendatton for dental or requested the applicants to be required to meet thefr burdens of proof on 13.3 percent of all cases in the 1977 aample. Thase types of coments, 16 in all, vere particularly directed to construction on barrler beachea. The comprised a quarter of all comments recelved by the croce from Stateride Planning, and the evidence In the flle Indicates the comments were Ignored. Ihts occurred even In those cases where the plaming agency suggested that environmental case law in other states may be of benefit to the Crux if it desired to deny the appIIcation, but feared the taking 1s8ue. In 18 cases, there were major substantive comments or recommendations for dental from the Department of Enviromental Management Blologists and/or Engineers based on potenetal and actual adverse impacts, the need for better plans, the need for impact evaluation, damage to sand dunes or saltwarsh or becanse of fIII below mean high water, or because the proposal was outIIght ineffective. There were some overlaps in these 18 cases with the 16 Statewide Planning cases. Again, the evidence on file does not favor the argunet that the CRuc serfousif considered technical advice (see Section B). The Large maforfty of the Assents lssued for profects did not have stipulat1ons (development standards) attached to iftigate site impacts. Although there are a couple of exceptlons where the GaMc required that the blologists stake the IImfts of a marsh (Cappuceto, 79-3-1) or the engtneers reIocate a structure to minimize adverse inpacts (Plectity, 76-8-6). Many cases have flles with so staff reports or only a scant amount of Information from any staff, Indicating that the dectsions were made wich more on the basis of Council member's perceptloos or destres.

The files contatn arple evidence that the practlce of "Iegal1zing" projects that were started and/or completed without an assent, was well astablished in 1977 (Raena 77-10-1, Saunderatown Tacht CIub 77-7-7, Pucet, 76-5-16, to vantion a few). One approval occurred with a Fater Qunity Ceretfication dental attached to it. Thte is a violation of the Cruic statute. The ares apparently was reclassifled from Class SA (highest) to SB (second bighest) at a later date to allow the CBMC perufted activity (Salt Rond Marine Rallway 76-6-5). 
The New England Telephone overseas underwater cable case (77-3-12) whtch was frequently referred to OCZM as an example of how the permitting process created beneficial modifications, has no reports on file to explatn what was done or why. Of the 120 cases that reached a dectalon, only Mello and Mello (77-10-7 and 77-10-8) for a stoglefamily dwelling and individual sewage disposal system in a marsh ares, constructed without a cruc permt, were effectively dented. This occurred in 1980 when the cases were discharged with prejudice by the CounctI, and the legal staff was instructed to proceed with civtl and criminal actions. These cases required 31 months to reach that point, and the structures had not been removed as of the end of 1980.

At least one case (Fortes, 7T-1I-5) typlfies the local disregard for Elood platn management and botlding code regulations where the applicant constucted a single-family dwelling with its lowest babitable floor well below the 14-foot mean see level bese flood elevation. It wes cases such as this, discovered through fleld spot checks by the Stateride Planning Prograw, the state's Flood Insurance Coordinating Agency, that led to the Gac atipulating flood elevation requiremeses on all assents. Sow CRcC numbers and some of the "old hand" staff three years later contloue to resent being backed into enforcIng someone else's program and regulat1ons. (It was also suggested by local residents to the author, durlog one fleld vislt, that local butlding inspectors who disregard the flood piato elevation should be Irvestigared for real estate conflicts of lnterest.)

Ore case (Btghft11, 77-2-1) was reported by staff, based on a site visft, to be beyond the GRMC's jurlsdict1on, get the person was still required to get Counctl approval. There is no evldence in the file auggesting the reason why thls apparent 11 legal exerclse of authorItr oceursed. 
H. Reflections on the IRDC Report on the Rhode Island Coastal Program, 1976.

The Rhode Island Program was first submitted to OCEM in June, 1976, for approval. As a necessary part of the approval process, a pablle bearing was beld on July 26, at the State House. A consorElum of enviromental groups Ied by the Matural Resources Defense Councll, Inc., a nonprofit national organization, concluded that the Cakc did not have the proper authorlties, powers, nor admintstrative operation to warrant approval by OCMM. Soreover, it concluded that the progran leseif did not fulfill oczu's mandate for definttions of perntacible uses, denfont ton of areas of particular concern and areas for preservation and restoratlon, and had not set guidelines for the prlortty of uses to the Bhode Island Coastal Zone.

The evaluation atated that "Itie Council cannot effectively control all activities baving a signiflcant impact on the coastal 200e." The CounctI's regulations in 1976 vere described as "too vague to resolve conflicts anong confllcting uses." 165 The Adinfistration of the progras did "rot compls wth the (Federal CZMA) requirements." 166 The boundarles were not clearly defined and there ras "too much discretion (placed Ir) the councll." ${ }^{167}$ There was a fallure to factlltate "the assessment of cumulative 1mpacts," and the program's impect approach wes described as "unfalr to developers." 168

It we the consortim's concluston that the IRDC's Model Coastal Towe Statute ahould be utflized by Rhode Island, and the ceatral feature of that nodal wae a zoning plan, 169 which fncluded "a land 
capabillty and land use element for the integrated arrangement and general location and extent of and the criterla and standards for, the use of land, water, alr, space, and open natural resources...."170. This type of an approach for Iand and water uses has been consistenty rejected by the CRuC and Coastal Resources Center personnel based on the argument for flextbillty in dectsion-making

The IRDC emphastzed the need for "Independent staff reports on $\therefore 17$ the record with detentled flndings. the concept of wakting the full staff report:avallable to Interested partles for zevlex before the full CounctI acted on the case, and proposed that wrtten findings by state agencles be placed on the record at the time of the staff report. Except for contested cases, thts procedure to now in place. All documents pertaintng to a particular case are published in an agenda format the Thursday prior to the Council's meeting on every sectond and fourth Iuesday of the month. Although deviations from thts practice are not uncomnow as cases are placed on the agenda at the last minutec.

There was a suggestion that local plans and ordinances be reDiewed for a lack of consistency with the state program and that the Cruc "adopt a spectfic" program for bringing local plans and controls 172 In compllance" with the state PIan. It was also recommended that Inemient sestatmee be provided to Iocal commateles. 173 The review of the local plans bae occurted, although na attempt has been made to achtere complfance. Techolcal assistance has been Ifmited to isoleted problems. 
Reflecting back on the concept of a zoning plan, the critique flatly stated that the CRMC "must be authorlzed to deal with all actiplttes....all areas....and all kfnds of impacts of activities in the coastal zone." I74 IRDC pointed out that the Rhode Island Program had been found defictent by MOAA sponsored studles, tn its abIIIty to controI these activities, areas and impacts. Bradiy and Armstrong stated that the Rhode Island Coastal Resources Management statute "by restrlcting Its coverage to speclfic activitles...does not provide any mechnisms to control the prolfferations of subdivicton devetopnets, privete hones, and indurtal plants other than patrolew and chamical factitfes. The act w11 bave to be amended to tnclude sweh activites before it can be conaldered to provide a complete program for coastal zone management." ${ }^{175}$ Thetr analyals wa essentlally correct. The act was not amended.

The IRDC approach was reaIly a Iand management scheme that the cric simply did not and does not bave the authortty to implement. Ind nonagenent Iegtolation in Bhode IsIand Is neceseary if concepts: such as those epressed by KBDC are to becowe realfty. There was preasure or: Bhode Island's Coastal personnal to go to the leglelacure to obtaln the neceseary authorities, but the CRoc resisted, because the tenor of the time in the state had shtfted from environpenteniter to econoife developnent.

The Frogran's Insbilfty to acquire Iand, through a statutory deffetency, was fiened ar a hiodrance because "such a power is necesaary to toplement the recommendetions emerging out les studies." Cited 
bere by NRDC was the Counc1I's barrler beach studies which noted that this lack of authortty "w1ll serlously undermine any report to manage land areas under the Counctl's furladiction." 176 Thts view was more strenuously emphasized "due to the unsettled nature of the "taleIng' question in Rhode Island." 17 NRDC attributed the CounctI's "soft" posttion, as evidenced through a lack of denlals, on the "tak1ng" 1saue and argued that the CRMC's fear of the taktng 1ssue stems frow the Coumetl's lack of eminent domatn power." 178 The Chatrman's response to this observation ts that one does not measure the success of a schoal by the number of stodents that fIunk out.

The power of enfnent dometn was included in the orfginal legIsInton drafted by the first Technical Commtttee, but was struck on the Insistence of local govermments. The lack of this power ostenatbIy has been the cause of the assents 1ssued on Coast Guard Barrier Beach for single-famfIy dwellings with ISDS.

The citique found partloular fault with the Councti's impect assesament procedure an described II the 1976 management program. That approach, described in Appendis A of the I976 management program, frvolved the staff preparing an evaluation of each proposal before the Counctl based on an ecoaystem evaluation. The site spectflc characterlstics would be compred to the proposad wase and activities and the potentell impact would be sesessed. The seaff report would recomnond dental. epproval or modtefeation. This ts not different from tha present procedure, except that the Councll objects to the staff miking recownandation to approve or deng. IRDC objected stremuous Iy 
to this approach. They wrote:

It is our contention that the use of this impact approach, without (emphasis added) a set of comrephensive and spectifc regulations to gulde the assessment of the Impact, Vlolates the letter and the intent of the Coastal Zone Management Act. Thto Impact approach seeks to turn this Act into a conpletely different law similar to the Natlonal Boviromental Pollcy Act. The impact approach vests too much uncontrolled discretion in the Coastal Resources Management Counc1l. The approach makes the assessment of cumulative impacts difficult, if not 1mposalble. The impact approach is infatr to prospective developers, because it gives them no guldance through present regulations. The impect approsch results in dectsion-maktng with Iow publtc Vlstbillty, makeng cltizen particlpation difficult, if not imposible. 179

If is tmportant to realize that IRDC did not say that the evaluation matrly was not good and should not be used. What was sald was that It could not be used alone, without more spectficity in the program. IRDC referred to the federal regulations, Sect1on 923.12, to butress 1te argument for the preparation of a "mapping of areas with a syetem of pecmisstble uses, "I80 ta provide this needed spectfictty.

The fsave of "too mech uncontrolled discretion" residing with the Cikic was not at all unfounded. The Rhode Island Superfor Court In the Spring, 1981, remaded a case back to the CRMC to take more evidence ox the central lasue of the case. The court concluded that "The CounctI abused 1ts discretion by denglng approval whout fully addreselng the (central) question" that algnifleant damage to a vetland I8I

wolld ceewr. The Cowrt aIso found that there was a lack of evidence to oupport the conclusion that the proposal conflicted with Section 120:0-2(D) (4) of the RICBMP, because "a reading of this section fatls to dtaclose what the CounctI's "plan" for cosstal retlands 1s, as 
basically all this section does is shift the burden onto the applicant to show that a proposal w1ll not significantly damage the coas182

tal enviromment. The Court also ruled that "Speculation concernIng posatble future uses of the land, such as for a dwelling untt is Improper... (and that) the CounctI's attentfor to these matters is prectsely why the Ieglslature bas creaced it and empowered it to Act." This is technically correct, but without a plan, one can only resort to speculation. And, ceallstically, once a profect "gets a foot-1nthe-door," the prectse lack of a plan makes further attempts to reguIate developwent corraodinarty difficult, tire-conguntag and cosely.

Instare and developers who wust deal with the present management procese have expresẹed thefr personal exasparation with the total lack of a solfd program to gulde them. What the program presently says, In an :urfter fashion, to you can apply for whatever, wherever you like, regardIese of what the RICRMP saye, and we will judge jour case on Its martes. This is precisely what OC2A and NBDC sought to put an end to becmse It crentes an atmophere of havoc, lesves the crac with too much descrettox and really is not resource management. It is prectsely the need for more spectfictey that is the focus of internal debate and the earget, hopefully, of a mor reviston of the RICRMP.

IIDC Iooked dfmif on the case-by-case approach to resource man-

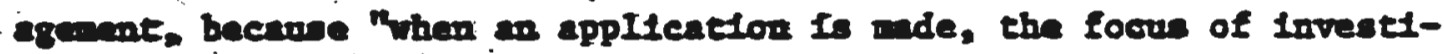

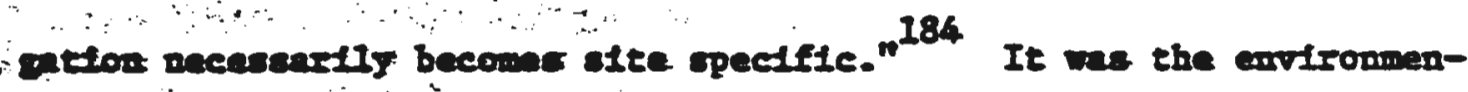
tat croug's contention that the Bhode Ialand and federal coastal Iars requited an ancesment of crimtative impacts. ${ }^{85}$ (See Chapter 3, Seation G.3, DAscussion of the Petequamscutt Rfver.) 
Writing four gears later in the Journal of the American Planning Assoclation, Sara Chasis lamented the lack of coastal states that provide for the assessment of cumulative impacts. She cltes OCay's response to NRDC's 1976 comments, that development of explicit cumulative tomact crlterta was not a requirement of the CaMA. This optnion was also offered by OCAM on the Massachusetts Program.. The RICRMP does require the evaluation of cumolative effects in some sterations (1.e. Section 310.0-2C2).

Brooks, and hts rescarchers, saw that the 1976 mnnagement program offared "no prospective developer.... clent ldes of whether he can or eamot proceed with his development. Every development, mafor or minor, must run the gamelet of the 1mpact assessment approach."187 Thts me Fiewed as belng administrattvely infeasible, and not a viable method of resolving we conflict. ${ }^{188}$ They foretold that the approach encourages conflet and Iftigation. 189 Furher, "The public bearing as apectifle appItcattor device does not appear to effectively pronot eftrien partetpatton." 190 And, the subatantive language of the 1976 program was not left unscathed. For instance, the language gov cunting the construction or alteration of sand dunes vas described ax "vague." 191

It If exrious that IRDC chose this section of the I976 program

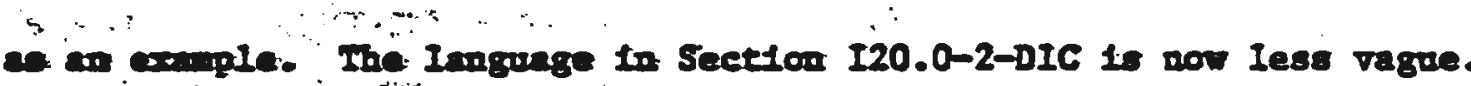
In fact, it is vers reotrletfre, but it did sot prevent the Council frow Loutng assents for stagle-fantly dwellings with ISDS on Coast Gund Barifer Besch, on the dune; an crertise of discretton. 
The Administration of the Coastal Resources Management Program came under close scrutay as well. Reports by the Untversity of Bhode Island Coastal Resources Center describing staff problems and a backlog of applications were cited as sources describing. "a sertous boteIeneck in the bnoling process." I92 These reports were dismfssed by the Difiston of Coastal Resources Chfef who reportedly clined that the backlog was no longer true and that the fulltime Iovent gators were more than able to handle the workload, although there was admfttedIy a backlog in the site monitorlng process.

The picture pained of realfty teself in the reatn of permit proceasing, beckIogs, staffing, and the Itke, hrve constantIy placed the state's program admintatrators in a defensive posttion, a posithon where they mat always try to make data that someone else prepared Iook good to themselves and the public. This phenomenon is dfscusaed in Chapter 3. A more recent example of the "admintstrative reeposse" refers specifically to Grant's 1980 program procedural reviene "It to hard to give spectic percentage on how wuch of the report has beer Incorporated into the banding process. It is apparent that the applfeation and permit process presently is much faster, accurate, and effletent than before the report." 194

IRDC reported that the record keeping oystem of the Division of Coaperl Resourcen we Incouplece and disorgantzed, a cheracterfstic whtch Tives publie sccountabiltt tuposatble." 195 The record keepIng gretex bas been the target of repeated evaluation. There was an effort to computertze the permtt record keeping system. The report EfIed by OCan's umagement Syaten Consultant on the Rhode Island per-

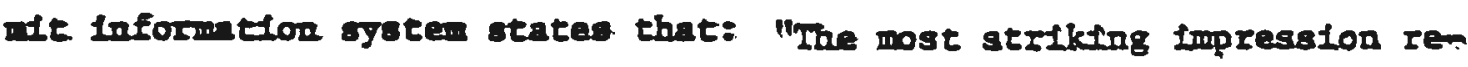


ceived by the author in studying the Rhode Island permit information system is that the automated system does not appear to be very useful..."196 An Internally generated report at the Division of Coastal Resources analyzed the entire record keeping system and presented a set of recommendations. Prepared during the summer of 1980 , the report has never been released.

NRDC reported that only a few applications go out to public hearing, and as such, a chamel of communtcation between the pubIf and the CBMC was underused. Bowever, it was noted that the "Iack of public heartags may be due to the larger number of applicattons having swall Impact in themselves." 197

The conclusion of this research is that there are far too many public hearlngs, a conclusion based on the fnformatt on gathered and the valfdtty of the obfectons that trtgger the hearing. These findings are not incompatible with the NRDC contention that public hearings are a valuable meams of commmication with the Cometl, and In sowe instances, they have proved to be so, but only when a case to for a proposal that is not in some way routine such as the destgnatom of a sancutary for SCUBA divers off Fort Wether111, Jamestown, or for a direct discharge of a chemical solution into the Seekonk Rfrer by a chemical company-

It was noted by the NRDE researchers that oaly a small number ar wa of appifcatfons were dented. The explanation offered by CBMC at that time was that the perwlteing process is a bargaining process in which applicatious are improved to a polnt of acceptability. 
SRDC contended that the alternate hypothesis would be that the Council has a strong development bias and therefore approves applications without proper consideration of the enviromental effect. However, to prove thts (or disprove it), a large sample of assents was suggested as necessary to determine if any of them had damaged the coastal zone. 200 If such a conclusion could be verffied, it would lend support to the finding by NRDC thit "Despite the management program applications appeal to all sorts of sctentific information, the reality of deciston-making on the CounctI's part in the past often does not reflect a serfous concern for facts and scientific conclusions."." It ts one of the conclustons of this research that the second hypothesis offered by NRDC is true. This is not to say that some bargafing does not occur or that profects are not altered by such bargatoing.

I. Assessment of the Effect of OCZM as a Polloy Source or Program Development and Implementation...

The wotng federal target affected the development of the Rhode Inland program; although it is not certain to Program Persomel that thits had a negative affect apart from the problems caused by rague202 nese. The state program was inftially submitted to oCzM for approval in June, 1976. In August, the state program personnel met with top OCaA personnel in Washington, D.C., to learn that the management prograw aubutted was unacceptable. The infetal wrtten response to OCZM from the atate was that "new persomel with new concepts" created vacillation at the federal level, and that the state was "expecting reltable direction, advice and cooperation from Fashington." 203 
The shifting target syndrome can be reasonably viewed as a product of the initial difficulties OCZM had encountered with the state of Washington's Coastal Management Program. Washington State had a programmatte approach, descrtbed by Grant in 1972, as stmflar to Bhode Island's, 204 and ft bad been reported at the 1976 Atrile, Virgtnia, State Cosstal Program Managers Conference that the WashIngton State Progran, approved a year earlfer, had k11led all bopes for Iand management in that state because of the tumoll the Coastal Progran had cansed. 205

Begardiles of axy ImpItcations of these tenuous comparisons betrewe Washington. State and Rhode IsIand, OCzM's response to Bhode. Inland's chagrin wae an assurance of addltlonal montes to continue the work nacessary to refine the state's program. OCZM assured the state that a posttive and detalled federal response to program developwent would occur, espectaIfy "wtth the changes and maturing in both the nettonat and state programe" that vere occurrting. 206

The drafters of the Bhode Island Program had placed heavy reIfance along the mey on the ocze Threshold Papers. They also reIled excluntivif or the state's Coastal Resources Management Act of I97I as the source of state authortty. It Is not umreasonable to assume that if problens had not occursed in Washington State and if

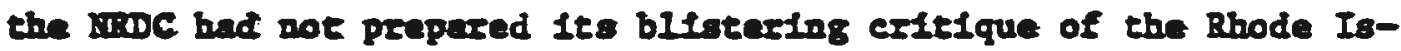
Ind Progran in 1976, the state would hive encountered Iftele diffteulty. 208 Howerex, the "maturtey" referred to by Brecht in bis September I4, 1976, Ietter to the state resulted in a mich more gunrded and careful examination of the 1976 Progran. Thetr reac- 
tIon to the program "amply demonstrated that they were extremely uncomfortable wth the amount of discretton the Council (CRMC) has retatned for 1tslef." 209 Moreover, the 1976 program relled on only those polfeles and regulattons which were in place, a fact viewed by OCnf as a weaknese because they feared a challenge from IRDC on a program "whose substance ts so openIy and admittedly incomplete." 210 The solution was to "Introduce more addftlonal structure and predictabiltty into the CounctI's internal deliberations." 211

The Office of Coasten Zone Kanagemant did belleve that it would be deairable for objectives and polleles to reflect themealves in manerable standards, which the I976 Bhode Isiand Program did not do. The state's poeftion was that such measurable standards, were "not achferable on the basts of the prelimtnary resource assessment... (but that it) may prove desirable for us to expand further on our resource assessment with the objectlve of developing more specific and detalled ateremenex or objectives. ${ }^{212}$ oczu also wes concerned how a person

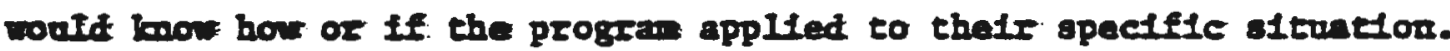
It was the state's positlon thet an applfcant know whether bts propoes I subfect to controls and or is permisstble and that the RICRMP provides a mintmon of ambigutty.

Batreen refection in 1976 and acceptance in 1978, the state was SIs to adopt a algiffeant number (15 out of a total of 21 ) of new

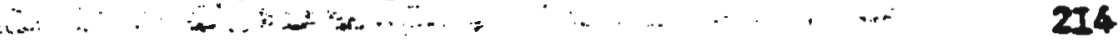
polfetes and regulation coverfor anj activitles, but the predictabitty of the Comeil's Internal deliberat1one was not necessar1 Iy enbanced. The need for standards bas been foremost in the minds of etate persomel tho are responstbIe for the day-to-day implementation 
of the program, and 1t is clear from dally interactions with the pubIf that applicants all too frequently learn of the Coastal Program at elther the last minute or after they have started their project. This can be accepted as a measure of amblgutty, and it is docmented If the Cease and Deafst Orders.

Obviously a major concern of OCZM and a 2 sason: for the 1976 Programs fatlure to gatn approval was the lack of apecifictty of the Program. OCZ4 wanted the Cauc to Ifmit Its discretion and a demonstra-

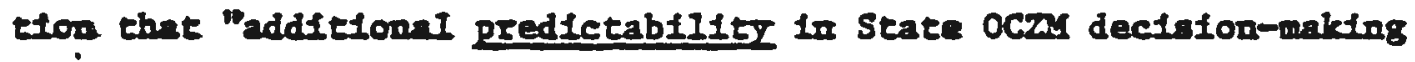
(would) reault fros 306 approval." Thls Included the Geograpble Area of Enrticular Concern (GAPC's) and the Areas for Preservation and Restorat1on (APR's). How, spectflcally, were APR's golng to be managed and/or protected? In the 1976 program, Rhode Island Included ports, herbors, and urban waterfionts as Geograpble Areas of Part1cular Concesn, but they are not so designated in the current program. OCan bud belleved that in 1976 too may arewe of the state were captured bs these designatlons, and the state was advised to "cut back" on these. 216 Thts has been to the state's detrfment because it has Ifofted the Program's ability to effect developwent in ports and harbors and has restrlcted these areas from the IImfted OCMM funding for GAPC's.

10 a polley gutdance mechnotom durlng Sect1on 306 1mplementation, ocau's track recosd is not beter than it was durlng progran develop-

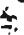
mant. It ang even be worse becauce ochu made litele effort to asaure that the atate progran corrected itentified defielanctes; whereas it - at Iense made the effort, albett Iargely at NRDC's behest, during pro- 
gram development. Several examples are 1IIustrative of this lack of Influence on the Program by OCZM.

The June 6, 1978, OCan Evaluation of the Rhode Island Program for the perlod January 1, 1979, to December 31, 1979, recommended the state program to improve its Internal commications "to ensure that each permit apflication recelves professlonal review to determine the probable impacts (of). the proposed actfolty." 217 a year later it was reported at the Jamung, I98I, OCZM evaluntion stte Flatt a case exibtetng precisely the evils that the recomnendation sought to re218 colve.

Ar applicant had recelved a Letter of so Objectlon to construct a single-family dwelling ofth ISDS. During the process of revising the ISDS plan, the applleant's proposal was evaluated through a foint cosstal/ISDS reviow by coastal staff. The staff recommended that the project be put out to a 30-day Notfce. The case came before the Gave on Oetobar 28, 1980, with an Incomplete file. Thia represented a deflation fros procedure. The CRMC accepted testimony on the record from Councti members, who are not expert blologlsts or englneers, that contradicted the professional staff findings. 219

V. Hicles: "Bow far is it from the vater?"

25- Dures: Tour or five hundred feet. That used to be a ertemingh If jears ago and haon't been a saltmarsh In the Inst scren or afght years that I kow of." 2. Hicks: "Is there aything in the file that showe that 


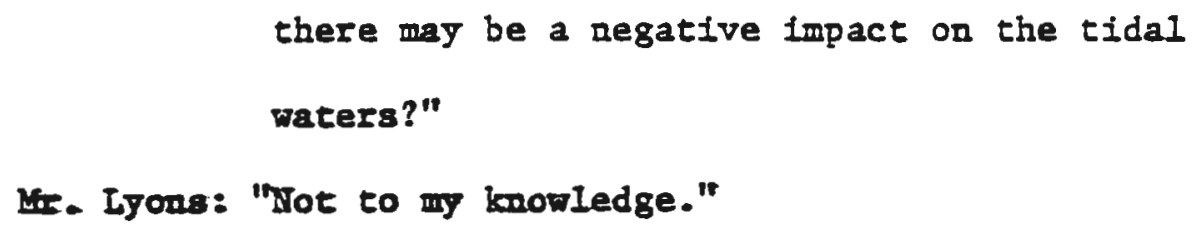

The project recelved an assent. The case is more interesting because the Cbairman has wrttter of observed and reported vlolations of the site impact mftigatton stipulations including dwelling construction not in conformance wth the flood hasardiregulation of the state BufldIng Code, and adverse impacts to the "Iarge phragmttes wetland," degcribed by the staff blologtst to be a salt and brackish marsh surrounding three sides of the property. 220

The oczy review also recommended that the CRMC "develop procedures for the twely and equitable disposieton of violations of its regulatrons. permits and Cease and Desist Orders." 221 The problem of bow to deal with Flolations has been an internal 1ssue with the Counc1l for some the. It is not resolved, and a revien of the coumell transerfpts from July, 1979, through December, 1980, reveal a constant patter of andous moments for Councll members.

- wuray, PIte 79-6-5 for an ISDS to replace a washed-out system on the beach along Block Island Sound. Lr. Brown: Mor are jou going to enforce regulation if you are going to condone what people brve been doing without aseanta? ${ }^{n 22}$

-Seceo, F11e 79-2-7 atructure on a beach, adjacent to a barrler bexich. 
15r. Turco: "I thiok Senator Canulla objected to this orfiginalIy because the applicant had taken actlon without an assent." 223

-Coleman, FIle 79-8-5 a SFDU/ISDS on Bhode Island Sound.

Nire. CoIt: "...thls particular applicant was told to stop bis work untl he bad a proper application and went ahead and did the work anyway. $" 224$

- Eenaral discusetion of Cease and Destse Orders on Aprti 8, 1980.

14- Btcks: "If somone goes out and brenic the Iaw, they should not be placed in an advantage.... We are coddIing the Iawbeaker and making the person that does it fight tor-the-1Ine. ${ }^{225}$

-Carr. FIle 80-6-5 for ax 11legally fotalled rlp rap wall on Polnt Judith Pood.

47. BradiatI: "What's the consensus of this Counctl as far as Ceare and Desist Orders are Concerned?"

j Hes- colte miney are weeless. 1226

Sutnst these expresstons of exasperation and hopleseness, OCZ4

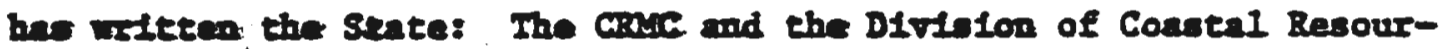
cen ahoult reduce the time to procese and 1soue nottces of violaetox and Casea and Dealet Orders in order to stop IIlegal activities of the exrliest poesible moment. 227 
And, in an instance where OCZM described the effectiveness of the CRMC as a protector of natural resources, the 1980 evaluation reported that "the CRMC has required buffer areas between proposed construction and wetland habitats as stipulations for CRMC assents. The buffer area is normally at least 50 feet wide, but may be as large as 100 feet, depending on the speciftc local condittons." 228 The review of cases reported In Appendix I revealed mostly 50-foot buffer zones, with a range from 10 to 60 feet. There were no 100-foot buffers durlng the sample perfod. This type of reporting by OCAM creates a false fmpression of the implementation of the program, but prectsely the type of impression that Iends itself alcely to the Council's public relations efforts. It completely Ignores the observed fact that once a project has started prlor to recelpt of an assent, any hope of preventing damage through the use of buffer zones is greatiy reduced. The emplacement of a buffer after site work ts started or completed negates its primary value of minimizing enFiromental damage during construction.

Sara Chasis of NRDC has concluded that because "no regulations have ever been Issued under (Section 312 CAMA) nor have clear objective standards been set for fudging a state's performance, determining whether or not a state is fustiffed is devfating from its program. "The 312 evaluaHons seem largely to whttewash problems." 229 It is her bellef that ocmi's Inofty will result in millions of dollars wasted and the coast will remain mprotected. 230. 
J. Internal Perceptions of the CRMC's Mission $1972 \mathrm{~V} .1981$.

On January 29, 1981, the CRMC held a "group dynamics session" that Involved persomel from the Department of Environmental Management Divisions of Cosstal Resources, Fish and Wildilfe, Enforcement, and Admintstrattor; the Statewide PIanning Program; the University of Rhode IsIand, CoastaI Resources Center; and members of the Coastal Resources Management Counctl. ThIs professtonally conducted all-day sesston was designed around a questlonnaire afmed at elfcting persomel perceptions on programmete goals, problems and soluttons.

S1x central 1ssues were Ideatified: ${ }^{231}$ (1) There is a programmate need to develop resources and area spectfic plans and Implement site spectfic polictes and regulations for critfcal coastal areas; (2) There must be better interagency coordination; (3) The permit processing system must be streamlfned; (4) There needs to be greater attenttox to enforcement of the program; (5) There needs to be a concensus among CRMC members regarding the program they have adopted; and (6) The public education (information) effort needs to be refocused and emphasized to support program goals and enforcement. These 1ssues are substantialiy the same as those 1dentifled at a sfmilar workshop held by the CRMC or: November 29, 1972, at the University of Rhode IsIand Paculty Center (Table 16). ur

Where one studies the summary of problems facting the CRMC in 1972 and places them within a use and activity framework, one can discern Ifttle reel difference between the two sets of 1ssues; the set developed fri 1972 and the one produced approxtmately 9 gears later. It appears 


\title{
TABLE 16
}

\author{
SUMMARY OF ISSUES RAISED AT BEGINNING OF CRMC'S WORKSHOP \\ Faculty Center - URI \\ November 29, 1972
}

A. USES AND ACIIVITIES OP COASTAL ZONE

residential and private

recreatlor and public access

boating and boating facilities

sport fishing

commercial fisherles

industry, commerce

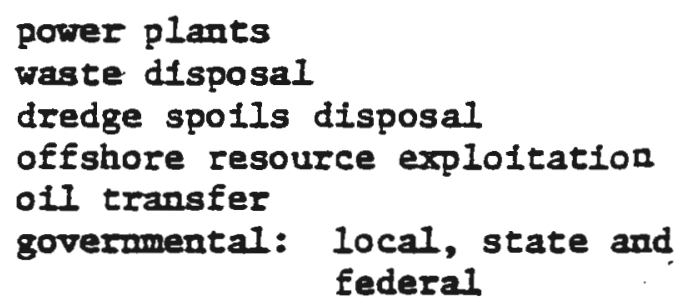

B. PROBLFMS BACING COASTAL ZONE MANAGEMIMII

conflicts within uses and activitles Ifsted above

Ights of ownership, use, condemation, compensation and protecElore

miteI-use shorellne

resource evaluation.

shore and harborline definftions

capital improvements funding

public understanding and forolvement

federal prerogatives

C. PROBLIMS FACING RHODE ISLAND CRMC

need staff, central coordination

funds for staff, research and management

set minagement priorfties.

aduintstrattve decision-making procedures

mosimize commmication within CRMC

madinfe comminication with other agencles and public

public educatton, brochures

interagency coordfration/competition: federal, state, local

Iaw clartfication

leglslation

enforcement

define furtsdictions and responsibilities

technteal Information for planning

zooning 
that time stood still. An explanation for this lies in a report prepared for the Coastal Resources Center in November, 1972. Entitled "A Brfef and Crftical Look at Coastal Management on the State Level," the report summarized the effort of the varfous coastal states to develop coastal zone management program. ${ }^{232}$ FIve states were identifled as having no significant activity; Twelve states were described as ut1lizing a "matrix" management approach which emphasized detafled and systematic resource identification prior to the preparation of a management program; Four states were identified with the "matr-1x-moratorfum hybird, which sought to control short-term developwent while the master plan was created; Ihree states were credtted with attempting a state-coumty regulatory approach in which the counties would be responsible for zonfing permissible uses in accordance with state guldeifnes; and only two states, Rhode Island and Washington, were Identified with the "organtzational" approach which emphasized direct and immedfate admintstrative: actfox. 233

The mafr charactertstic of the organizational approach is the development of a functlonal management mechantsm (1.e., CRMC) equipped to deal with pressing developmental problems, with its actlons "gulded by a general statement of management phtlosophy."234 The advantages to this approach were described as: (I) creation of the ability to deal direct If with crittcal problems demanding an imsediate management response; (2) gradual accumalation of ftnanctat and personnel resources: (3) creation of the appearance and reality of a responstive organtrat or, thereby stimulating public support and liscouraging "bureauerate footdragetng." 235 
The report was quick to point out, however, that the very things perceived as strengths could at once be the greatest weakness. That 1s, by creating an aura of urgency and crisis around many decistons, the approach encourages rash, 111-considered and 111-concelved responses; a tendency to overreact to whatever was percelved as an obvious threet while 1gnorling less dramstlc but equally important responsibil1ties; and the system "may find Itseli bound 1nto a 'brush fire' men236

talfty." The organizattonal approach was seen as espectally dangerous because it issued a mamagement approach that would postpone forceful dectolons on mafor polfcy lssues, thereby effectively removing control of major developments. from the management process, while bogging the system down in routine decisions handled on an ad hoc basis. 237 The history of Rhode Island's Coastal Management process and the case load amalysis certainly affects a reality that mirrors the most feared predicted outcome discussed by Grant 1n 1972. 
1. State of Rhode Island Coastal Resources Management Program: March 14, 1978, (Providence, Rhode Island) Coastal Resources Management Comac1, 1978), p. 284. Hereafter cited as RICRMP.

2. 패으-, P- Iff.

3. Ibid-= Pp-11, 1ff.

4. Ibid., P. 41.

5. General Laws of Rhode Island, Chapter 46, Section 23-6, Bd.

6. Ibid.

T. RTAROP, SUmmET DEIS.

8. Ibld, P- ift.

9. Ib1d.

10. General Laws of Rhode Island, Chapter 46, Section 23-6B.

1. IbId.

12. Ibid.

13. RICRMP, PP. 4I, 42.

14. Ibld-. $\mathrm{g}-31$.

15. Ibld- $=9-32$

16. Ibld.

17. Ibid.

18. Ibid.., P. 56 .

19.: IbId. PP. 56-58.

20. Cosetal Resources Center and Resources Management Systems, Inc., whe Cosetal Resources Management Progran: A Handbook for Fermet AppIfcants," (Kingston, RI: Oniversity of Rhode IsInd; Jume, 1978). 
21. Rhode Island Coastal Resources Management Council Application, Charron \& Sons, Inc., File 80-6-9. See also State of Rhode Island and Providence Plantations Coastal Resources Management Council Regular Monthly Meeting (August 14, 1979, TRANSCRIPT, p. 21. Statement on the record: "there are no written objections. We consider if somebody wrltes a letter, other than the staff, we consider that wrttten objection." (d1scusston on Rasdon, File 78-1I-11, for a wall and Ip rap along Rhode IsIand Sound, Newport).

22. RICRMP, p- ift.

23. Rhode Island Coastal Resources Management Counctl Applicat1on, Four twenty Corporation, File 79-12-5. See also CRMC meeting Pebruary 26, 1980, IRANSCRIPT, PP. 30-38.

24. RICRTP., p- 11 .

25. General Laws of Phode Is Land, Chapter 46, Section 23-6A.

26. Erank P. Geremia, Aselstant Director for Operat1ous, Rhode Island State Department of Environmental Management, Inter-Office memo regarding volume of paper, December, 1980.

27. RICRMP., p. IV.

28. Ib1d-. p. 275 .

29. IbId.

30. Divfsior of Coastal Resources, Department of Environmental Managemeat, Coastal Zone Management Annual Report for F1scal Year 80, (erovfdeace, RI: undated) p. 3 .

3I. The Providence Jownal Company, The Providence Journal, "R.I. PIamers Accuse Coastal Counctl of Inert1a, Waste and Sloppy Work," Jume 22, 1979. The CounctI's reaction is an example of the "Bumker Mentalfty" noted in Chapter 2, Sect1on E.

32. John A- Lyons, Chatrman, Coastal Resources Management Counc1l, June 28, 1979, Letter to Governor J. Joseph Garrahy.

33. Off1ce of Coastal zone Management, Section 312 Findings, Evaluation of the Bhode Island Coastal Management Program Covering the Grant Perlod, May, 1978, - February, 1979, (Washington, DC: ApriI 19, 1979) p- 10.

34. Iold- PP. T, 10 .

35. Difision of Cosstal Resources, Department of Environmental Management, Coastal Resources Management Section 312 Program Review and Evaluattorn, (Providence, RI: February 5, 1980), P. 3. 
36. RICRMP, p. 41.

37. Richard J. Amato and Lee R. Whitaker, "Rhode Island Coastal Community Land Use Review: A Study of Resources A110catton in the Coastal Communtty," In Resource Allocation Issues in the Coastal Environment, proceedings of the Coastal Soclety Fifth Annual Conference, (Alrlington, Virgtmia: November 6-8, 1978) p. 150.

38. Ib1d.

39. Private conversation with Mr. Robert Fredericksen, Providence Journal Company Conservation Writer Jume 21, 1979.

40. Offtce of Coastal Zone Management, Evaluatton of the Rioute Igr Iand Coastal Management Program. for tite Grant Perfot From January I; I979, to December 3I, I979, Chasifington, DC: Jume 6. 1980I, P. 2.

4I- Diviston of Coastal Resources Department of Enviromental Management Coastal Resources Management Sectlor 312 Program Revier and Evaluation, (Providence, RI: February 5, 1980 ) PP - 2, 3 .

42. RICRMP, Section 120.0-2-D4, p. 46. There is pressure from the Chatrman to relax the saltmarsh standards and it is speculated that the motivation to do so is to. Ieduce the number of vtolations, thereby maktng the program and CRMC look better.

43. Rhode Island Stateride Plaming Program, Department of AdminisEractor, Report No. 22, Rhode Island Land Use Pollefes and PIan, (Providence, RI: Jume, 1975) p. 161 .

44. Division of Coastal Resources, Department of Environmental Management, CoastaI Resources Management Section 312 Program Revier: and Evaluarton, (Providence, RI: February 5, 1980).

45. Staff Reports to the Rhode Island Coastal Resources Management Coumctl and Division of Coastal Resources, Department of Enviromental Management, Log Entries.

46. Division of Coastal Resources, Department of Environmental Management, Coastal Zone Management Annual Report for F1scal Iear 1980 . (Providence, RI: undated) Table I.

4. Ibta.- Pa 2

48. This argument 18nores the contention that residentlal development on some barzler beaches such as Coast Guard:Barrter Beach, Ifer Shoreham, or all barrler beaches, should be prohtbited. 
49. East Greenwich Yacht Club et. al. v. The Coastal Resources Management Council, et. al., Supreme Court Opinion, No. 75-280 M.P., Juiy 11, 1977, p. 8.

50. Dalmazto 0. Santini $\nabla$. John A Lyons, et. als., Superior Court Dectsion, C.A. No. 74-3158, C.A. No. 74-3159, and C.A. Na. 79-1162, filed May 15, 1980, pp.9, 10.

5I. Sebastian Milardo V. The Coastal Resources Management Counc1l, et. al., Superior Court Decision, C.A. No. 77-735 and C.A. No. 77-2245, filed June 7, 1979 :p. 9, 10.

52. John A. Iyons, et als. v. Nancy F1lliors, Supertor Court Declslon, C.A. No. 72-182, no file date, p. 14 .

53. Hangy B. FIIImore $\nabla$. John A. Lrons, et. als., Superfor Court Dectsion, C.A. No. 73-2373, no file date, pp. 4, 5.

54. John A. Lyons, Chatrman, Rhode Island Coastal Resources Management Counc1l, Letter to Mr. George Favre, Ed1tor, Bd1tortal Department, Providence Journal-Bullet1n, September 15, 1980.

55. The Narragansett Times. "South Kingstown loses key beach building ban dectston." October 16, 1980; and the Provtdence Jourwal Company, The Evening Bulletin, "Barrler Beach Construction bew held iliegal," October 16, 1980.

56. See Bernard J. Frleden, "The Consumer's Stake in Bnfironmental Begulatton," The American Academy of Polltical and Soctal Sefence: The Amals (PhIladelphta: September, 1980), VoI 45I, pp. 36-44. While Erleder's thesis is not narrowly applied to one sensitive resource type, his conclusion is no less true: that growth control and environmental politics rafse costs to consumers while contributing little to the improvement of the public envilromment.

5T. RICRRP, P. 28, See also "Prlortites for Use in the Rhode Island Coastal Regton."

58. Coastal Resources Management CounctI, TRANSCRIPI, August 14, I979, p. 31.

59. IbIä-, P. 36 .

60. I01d. Pp. 35-36.

6I. IbId-, P- 38 .

62. Ibida, P. 93.

$40+6$ 
63. RICRMP, pp. 11, 16. See also "Geographic Areas of Particular Concern (GAPC) and Areas for Preservation and Restoration (APR) in the Rhode Island Coastal Region."

64. Coastal Resources Management Council, TRANSCRIPT, August 14, 1979, pp - 91-92.

65. Ibid.,. P. 93.

66. IbId.. P. 95.

67. Ib1d., P. 96.

68. Border Mill Mobile Home Park, Inc., File 76-12-9, Assent No. 60-B.I. Sound -77 .

69. Ibid.

70. Border HiII MobtIe Eome Park, Inc., F1le 29-7-13, Recomendations of Subcominttee.

71. Coastal Resources Management Counc1I, IRANSCRIPT, February 12, 1980, P. 37 .

72. Border Hill Moblle Home Park, Inc., F1le 79-7-13.

73. Johr A. Lgons, Chatrman, Coastal Resources Management Counctl. Letter to George W. Greene, Prestdent, Border B111 Mobile Home Park, Inc., February 21, 1980.

74. Ib1d., Pebruary 23, 1981.

75. Cosstal Resources Management CounctI, TRANSCRIPT, March 24, 198I, Discusfon on Cove Haven Marina, F1le 75-10-12, to construct and matntaln floating plers and to dredge an area 300 feet by 210 feet to 5 feet wean low water in Bullocks Cove.

76. CoastaI Resources Management Counc1l, Dectslon, Pet1tion of Edward and Shirley Ventura, Docket No. 79-7-19, p. 1.

77. IbId., P. 2.

78. Ibfd- $=$ P. 3 .

79. RICROP, P- 28.

80. Retor. PIIe No. 81-1-8.

g. Venture, P. 2

82. WeItfam Barnack V. The Coastal Resources Management Counat 1.. of the

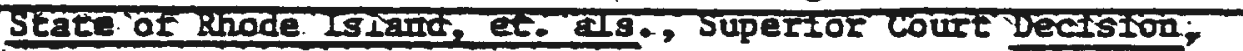
State of Rhode Island and Providence Plantatlons, SC, Prov1dence, C.A. Na. 79-3842, p. 15 . 
83. The CRMC's (1.e., the state's) jurisdiction over coastal waters below mean high water has been upheld in court. James Betres et. als. V. Coastal Resources Management Council, et. als., Superfor Court Declsion, State of Rhode Island and Providence Plantations, SC, Bristol, filed September 26, 1980, C.A. No. 78-3858, P. 3 .

84. Amnto and Thiteaker, p. 143.

85. Ibid., P. 142 .

86. Ib1d.

87. Lee R. Whitaker, Senfor Planner, Bhode Island State Department of Burfromental Management, Division of Coastal Resources, Letter to Stephen B. Olsen, Coordinator, Unfversity of Rhode Island, Constal Resourced Center, October 2, 1980.

88. IBid.

89. Inte.

90. John 1. Iyons, Chatrman, Coastal Resources Management Counc1I, Leteer to Adrlan Golman (sic) and George Sherwood, November 29, 1979.

91. I01d.

92. Nicholas A. P1sant, "Mhode Island Coastal Resources Management Councll Bngtneer's Fleld Report," slgned and dated November I, 1979.

93. I5td.

94. NIcholas A. Plsant, Civil Engineer, Inter-0fflce Meno re: Goldman and Sharwood, Quonochontang/Charlestow, March 11, $128 I$.

95. Ib1d.

96. IbId.

97. Jim. Parkburst, "Rhode Island Coastal Resources Management Counc1l Blologine's fleld report," Karch 30, 1981, report on Callahan.

98. Currles W. Int, ButIding Inopector, Tow of Charlestown, Letter to Couserl Resourees Managenent Counc1I, Jammary 16, 1980.

99. 10id

100. The Memil Eerald, "Cosetal Zone PIan Proves PerpIeadng," Apr11 16, 1978.

Ion: Ibld.

102. In1d. 
103. Daniel R. Mandelker, "Symposium: Law and Planning in the Environmental Decade," Journal of the American Planning Assoctat1on, Vol. 46, No. 2 (ApI1], 1980), p. 133.

104. Sara Chas1s, "The Coastal Zore Management Act," Journal of the American Plaming Assoctat100, Vol. 46, No. 2 (ApI11, 1980), pp- 147-148.

105. IbId-. P. 148.

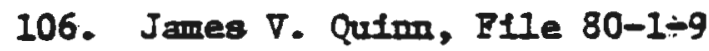

107. Alfred L. Hawkes, Erecutive Director, The Audubon Soclety of Rhode Island, Letter to Joln A. Ljons, Chalsmin, Coastal Resources Management Counctl, Pebruary 25, 1980.

108. Inld.

109. EICRP, P- 13

110. Gilbere A. Plumb. E1Ie Bo. 78-9-5, Assent No. 113-Block Island Sound-78, Lsoved 16 November I978.

111. Ibld., Inter-Office Kemo from Dantel W. Vartn to John A. Lyons, October 4, 1978.

II2. RICRMP, P. 42 .

113. IbId., P. 51 .

I4. Jobn A. Iyons, Chairman, Coastal Resources Management Counc11, Intece to Gilbert A. Plumb. November 14, 1979.

115. K Tovenber $28,1980$.

II6. Hobert Carter File 79-7-16; Richard Devereaux F1le Nos. 79-9-17

$\because \quad$ and $79-9-18$.

117. The Rrouldence Journal Company, The Provldence Journal, "Coastal counctl challenged ox beach homes," September 12, 1980.

118. Jobm A. Iyons, Letter to George Bave, Editor, Editorlal Development, Providence JournaI Bulletin, September 14, 1980.

119. The Erovidence Journal Company, The Provtdence Journal, "Preserve Block Ialond Beach" September 14, 1980.

120. B. Dinter Prentiss, "Construction perifts for barrler beaches," Leter to the Bditor, The Providence Journal, October 19, 1980.

12I. The Providence Journal Coupany. The Provldence JournaI, "Roberts to sue Cosstal Counetl af Permits Given, November 20, 1980. 
122. Ibid.

123. H.R. 598696 th Congress and Audrey L. Dixon, Coastal Barrler Islands Project, Letter to John A. Lyons, Chairman, CRMC, July 16, 1980.

124. Johr A. Iyons, Letter to the Bonorable Philip W. Burton, J.S. House of Representatives, March 25, 1980.

125. Block Isle Corporation, File 81-2-1. Conant, F1le 80-1-1; 8I-3-1.

Sorenson, P1le 80-10-20.

126. Sorenson, F1le 80-10-20.

127. Howell Conant letter to GRic, Pebruary 14, 1981.

128. Hichnel Glazer, HOAA, OCY, Asalatant Admintstrator, "Bvaluation of the Bhode Island Coantal Mnagenent Program for the Grant Pertod from January I, 1979, to December 3I, 1979," Jume 6, 1980, p. 8 .

129. John A. Iyons, Chairman, CRuC, ROIICE Jue 26, 1980.

130. Lee 8. Whttaker, "Warrow River Pollcy Options," Inter-Office Memo to the Coastal Resources Management Counc1I, June 30, 1980. It 18 Important to note that these att1tudes were not obtalned through a statisteally valld quastlonnatre or some other "sclentific" means. They were the observat lons of the author obtatned through intecviewe with local govermental planning offlctals, a local public works engineer, professional staff at the University of Bhode IsIand Coastal Besources Center and withln the state Departwat of Enviromental Mmagement, and members of the darIow Rifer Bzesarvation Assoctatior. Inc.

13I. Ifide; P. 3.

132. RIGRIP, P. 32 .

133. RICRRP, p. 131.

134. Ibid.

135. Town of South Kingstows. F11 76-3-15.

136 . Ibid.

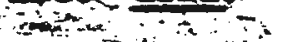

I3T - Tow of Alrracanact - F1Ie 79-8-15

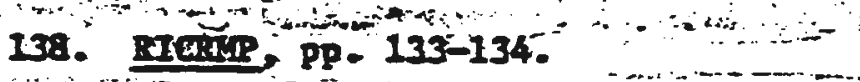

139. Tow of Rariaganset, F11 80-9-13

140. Tow of Rarragansett, Fife 80-3-9: IRAKSCRIPI, August 12, 1980, p. $4 I$. 
141. George I. Seavey, Rhode Island's Coastal Natural Areas: Prlor1ties for Protection and Management, (Kingston: University of Rhode Island Coastal Resources Center, 1975), pp. 39-41.

142. RIver Landscapes, A PIan for the Narrow River Watershed, prepared for the Tri-Towir Narrow RIver Planning Committee, (Cambridge, Mnsachnsetts, Roy Mann Assoclates, Inc., and Maurfce and Gary Inc., Jume 1976), P. 12. Funded by OCRM and GRMC in part.

143. Ibid- -14 - 14

144. Ib1d., pp. $1:-I 5$.

145. Jobm Mar Sleburtb; Water Qualfty of the Narrow Rfver 1959-1979 (Harrow River Preservation Assoctation: Undated), p. 5

146. RIPE, Ine., Peteaguanscutt Rfver Ind17fdual Senrage Disposal Sy8teme StudY. (Wakefield, RI: RIPB, Inc., undated), p. 34 .

147. Robert E. Richnrdeon, State of Rhode Island and Providence Plantations Department of Enviropmental Management, Division of Water Resources, Shoreline Survey and Shore Sampling of Pettaqumacutt Rfver 4, 5, and 13 September, 1979. (Prov1dence, Bhode Island, BIDEM, October 5, 1979), p. 4

148. The Narragansete IImes, More River SampIing Promtsed," Decenber 4. 1980 .

149. Anon Prager, Town Plamer, et. al., Letter to Coastal Resources Managemeat Counctl regarding file No. 79-8-I8 (Harry Readybough). September 28, 1979.

Jack Bran, Fresident, Federated Rhode Ialand Sportsmen's Clubs, Ine-s September 24, 1979, Letter to Coastal Resources Managemene CounctI Iegarding Piles 79-8-15, 79-8-14, 79-8-18 and $79-9-1$.

I50. Yha Beck, Recordfng Secretary, Town of Nerragansett, Conservetfon Comisston, Latear to Coastal Resources Management CounctI regarding F1le 79-9-33 (Filliam Shea), October 23, 1979. Suarm M. Pavao, Secretary, Mettaturet Improvement Assoclation Leter to Coastal Resources regard1ng Blle 79-9-33, November 9, I979.

151. Dafiel Tr. Varte, Chief, Statewide PIaning Progran, to John A. Ijone, Chntring, Coantal Resources Hmagenent Councl1, statenut for the record of the pubIte hearting on File 79-11-8 (Stracmir I. Ifindberg), Jamuary 21, I980, (roLE: Application was Ithdrawn by applficant and discharged by CRLC).

152. Thouns A. Greene, Second V1ce President, Bederated Rhode Island Sportanen Club, Inc., October 31, 1979, Letter to Coastal Resoures Kanagement CounctI. 
153. RIver Landscapes, p. 22.

154. Ib1d., p. 23

155. IbId., P. I8.

156. Ib1d., P. 28. Note: There is evidence of construction of residenttal dwellings below the base flood elevation along the Fiver. Reference Jose Fortes Ftle No. 77-1I-5 approved December 16, 1977, stx months after the July 1, 1977, State Butlding Code Rules and Regulations for construction in Flood Hazard Areas.

157. Ib1d., p. 31 .

158. Fold.. P. 32. Reference Files 80-1-19, 80-9-13 for $16^{\prime}$ force main poing seation.

159. Iold.. P. 34.

160. W.E.R. LaParge, Preaddent, Narrow Rfver Preservation Assoctation Inter to John Iyono, Chalrman, Coastal Resources Management Cometl, Eebrunry 14, 1980.

161. Constal Resources Management Counc11, IRANSCRIPI, January 8, I980, Pp. 35-36, Discusaton on Grove, Pile 79-9-1.

162. Ibld., Karch 11, 1980, pp. 18-23, D1scussion on Howard, File 79-7-5 for a angle-famtiy dwelling with ISDS on Central Barrier Beach at Quonochontaug, Charlestown, (see also Chapter 36 2A).

163. R1chard 0. Brooks and Kenneth Payne, et. als. "Presentacton of the Audubot Soctety of Bhode Island, The Natural Resources Defense CounctI, Inc., Bcology Action of Rhode Island, Inc., Conservation Lav Roundation of Bhode Island, American Itteroral Soctety, Inc.," Before the Rhode Island Coastal Resources Management Courctl, July 26, 1976, State House, Rhode Island, pp. 4-6.

164. Ibld.: P. T.

165. In1d., P. 8.

166. Ib1d-1

167. Inld-

168. Ibta.

169. Io1d., Pp - 10-14.

170. IbId. p. II.

17I. IBId.. P. If-18 
172. Ibld., P. 19.

173. Ibld.

174. Ib1d., P. 19-20.

175. Ibld.. p. 28.

176. Ibid.. 8. 29.

I77. Ibld $=\mathrm{p} .30$.

178. Ibld. . p. $3 I$.

179. Ibld., P. 43.

180. Ibtd. . P. 45 .

18I. HIIIom Barnack $\nabla$. The Coastal Resources Management CounctI of the State of Rhode Island, et. als., Superlor Court Dec1sion, State of Bhode Island and Provldence Plantations, SC. Provtdence, C.L. TK. 79-3842, p. 15 .

182. Ibtd.: 16 . 16

183. Ibld., P. 12 .

I84. Brooks and Payne; p. 47.

185. Ibid., PP. $47-48$.

186. Chas18, P. I50.

187, Brooks and Payne, p. 48.

188. Inta-

189. Inid.

190. Ibld. p. 49.

191. Ibld.. p. 87 .

192. IbId. = p. 91 .

193. Intd. - p. I9Z.

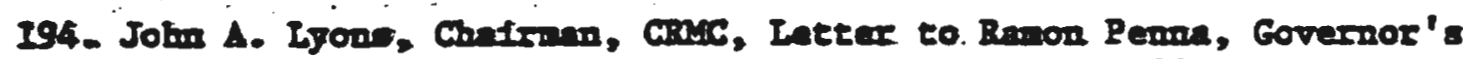
Office on Coantal zone Mnagement, September 29.

195. Brooke arid Payse, P - 94 .

I96. David B. Eumbberger, Management Systemn Consultant, "Survey of - Coneral zone Permit Informetion System, State Site Visit Report: Phode Island," draft for comment, December 17, 1979. 
197. Brooks and Payne, p. 94.

198. Ibid., P. 95.

199. Ib1d., p. 95.

200. Ibld., p. 97 .

20I. InId.. P. 110 .

202. Malcolm J. Grant, "Rhode Island Posit1on Paper on State ObIfgations Under Sect1on 306 CZMA, State Response to those Obl1gat1ons," September, 1976.

203. John A. Iyons, Ietter to Mr. Bobert Kneche, Assistant Admintstrator, ocen, August 19, 1976.

204. UnIcoln I. Grant, "A Brtef and Grietcal Look at Coastal Management or the State Level," for the Cosstal Resources Center, Untveretty of Rhode Island, November, I972, p. 5.

205. Iee R. Whitaicer, personal recollection of a discussion of Coastal Zone Monagement and Land Management with a Washington State Coantal Knnagement staff persor, 1976, Alrlie, VIrginla, State Coastal Program Managers Conference. Rhode Island was on the thresbold of enacting land use management legislation in 1975. The effort fatled.

206. Bobert W. Knecht, Ass1stant Admfotstrator for Coastal Zone Management letter to John A. Iyous, Chatrman, Coastal Resources Man$\therefore \quad$ agenant Councti, September 14, 1976.

20T. Grant, "Obligations."

208. OCA4 Administrator, Knecht, wa viewed as a frlend of the Bhode Ialand Program partly because he had been a graduating member of one of the first Masters of Martine Affatrs Programs.

209. Grant, "Ob11gat1ons," P. 54.

210. ㅁ.d... p. 31 .

211. Ibld.2 P. 55.

222. Ibld - : . 2 .

213. Intd-. P. 9.

214. Robert W. Kreche, "TIndings" for approval of the Rhode IsIand Coastel. Mnagement Program, Kay 12, 1978, Pp. 3, 4.

215. Grant "Oblignetons." P. 3. 
216. Stephen 01sen, Letter to Grant, Lyons, Esposito, Whitaker, Ze1t I1n-Hale, November 23, 1976.

217. Mtchael Glazer, Assistant Administrator, Office of Coastal Zone Management, NOAA, "Evaluation of the Rhode Island Coastal Momagement Program for the Grant Period from January 1, 1979, to December 3I, 1979" June 6, 1980, p. 9.

2I8. Response to the Request for Informat10n Regarding the Thtrd Amual "312" Revlew (1980) of the Rhode Island Coastal Resources Management Program, undated, pp. 59-60. Case of Roy $T$. Boward, F1le No. 80-9-18.

219. Coastal Resources Management Counc1I, TRANSCRIPT, October 28, 1980, pq. 58-60.

220. John A. Ijons, Chatrman, Coastal Resources Management CounctI, Ietter to Boy I. Howard, B11e 80-9-18, C1t1ng three st1pelaton: violationa, Larch 31, 1981.

221. Glaser, Evaluation. P. 9.

222. CoastaI Resources Management Counc1l, TRANSCRIPT, JuIP 10, 1979, P. 64.

223. IbId., August 14, 1979, p. 77.

224. Ib1d., September 11, 1979, p. 41.

225. Ibid.. Apr11 8, 1980, P. 35.

226. IbId.* Anguet 26, 198I, p. 65.

227. GIazer, BvaInatiog, p. 9.

228. Ib1d- $=$ P. 5 .

229. Chaste, P- 152.

230. Ibld., P. 153.

231. Stephen 0Isen, Memorandum to Inv1tees to the January 29. Coastal Resources Hanngement Program Workshops, February 16, 1981, PF. Ix 2

232. Hafeol J. Grant, " $\Delta$ Brief and Critical Look at Coastal Management os the Strte Ind," for the Conatel Resources Center, Dntiverdey of Bhode InInd, Kovember, 1972.

233. IbId--

234. 파d.

235. IBId., P. 6 . 
236. Ib1d.

237. Ib1d., p. 7 . 
He don't Ifre in Plato's Comonwealth, and when we can't have perfection, we ought to comply wth the measure that is least remote from $1 t$.

- Thomes Hutchinson 
CHAPIER FOUR: FINDINGS AND RECOMMENDATIONS

\section{Iurtisdiction and Control.}

\section{Elndings:}

a. The Stratton Commission at the Natlonal level and the Rhode IsIand Governor's First Cominttee on the Coastal Zone emphaelzed the need for a strong state role in coastal resources nangement.

The Bhode IsIand Program evolved wth a strong Iocal represantation in the mangement process, resulefng in a program doutrated by Iocal dectsion-maktng and an att1tude toward resource management that is aktn to campand11sm, that is, short sighted and narrowly focused.

b. The RICRuP leaves to local zoning and extsting land use patexre the determination of the prlortty for use of the land, treluding the land olthtr 200 feet of the water. This in so small measure dictates the use of the immediate near-ghore mets and potental effects of development on physiographtcaI features. These uses have short- and Iong-term Impacts

$x$ or the areas under state control, but the atate has little or (.) no control over their determination.

C. Lt the presant rate of development in coastal communtiles in areas with close prosdmity to coastal waters and phystographle features, lack of state control or atrong influence over land ase w1I foreclose the prospects of future state 
management of the land and makes it difficult to impossible to control the effects of land developwent on coastal waters and physiographical features.

d. The Rhode Island Coastal Region is a furtsdiction patchwork as a result of coastal resources management. The 200-foot loland zone, whych is designed to protect coastal physiographical features, does nothing to determine use. It 1s, zather, a zone for site 1mpact mitigation purposes and confusion occurs over the authortitles exercfeed withln 1t. Even ou barrler beaches where the state's authorfty to paramount, the Cauc typlcally accedes to local authortties.

e. The Councll has falled to adequately fulfill 1ts legislative mandate of 46-23-64 of the General Lawe of Rhode Island which require that the resources management process shall tnclude the following basic phases:

(a) evalunte these resources in terns of their quantity, qualfty. capabiltty for use, and other key characterfstics;

(b) deternine the current and patential uses of exch resource:

(c) deterifine the current and potential problems of each resource:

(d) formatate plans and programs for the management of each resource, Identffying permitted uses, locat1on, protection measures, and so forth;

(d) carry out thene resources mnagement prograns through implemenfing arthorth and coordinntion of state, federal, local, and pritrete activites; and

(f) formalnte standards where these do not extet, and reevaluate exaefing standards. 
It has Instead adopted a management program that is very processorlented through its rellance (legltimately so) on the state's Administratlve Procedures Act, but which contains l1ttle substance of its own. What it does have for substance is broadiy applled destgnations and reguIattons that do not accurately reflect reality and achleve desired ends in the areas of their spectfic application.

\section{Recommendattons:}

a. Bor more effectre and efflclent coastal resources management, thare needs to be atrengthenfing of the state's authortty in reeping with the Governor's first Committee on the Coastal zowe and the Stratton Comnssion's recommendations. Minfmally, there reeds to be the development of apeclal area plans and nore clearly stated permissible use. There also needs to be an adoption of state standards governtng setbacks from coastal phyelographlerfeatures, construction elevations and de1gre, buffer zones in accordance with site spectflc conditions. arosion and sedinentation controls for profect types and for areas prone to erosion, development density requiremonts, runoff controls, and locationel (or siting) criteria. Prelfininary Development Standards are offered in Appendix I. These can be adopted and 1mplemented at the local level, Implenented or a case-by-case basis by atate enviromental manageneme seaff as presentir done, or by a comblnation of the tro anthods. Baved on the prenent recoed of the inability of 10cal buflding Inepectors to render dectsions in accordance Wth the RICrop, the ovidence strongly suggests retention of 
maximum amount of state-directed professional implementation of these standards.

b. In terms of rductng permit processing and other costs to indfviduals; Implementation of Iandside standards and permissible uses by the local untts of goverment is an attractfve optlor, provided strict 1mplementation in accordance With the adopted standards occurred. This oll1 require enabring legislatton. The state-local land management legisIation could be a vehicle for this. It, or something simflar for the coastal region would be requifed because there is a Ieck of Iocal authorlty to even enforce CBMC permit restricthons. Federal CZMA montes could be passed through the state program managex's offtce to local goverments, once state standarda are much more clearly enunctated. (and adopted), to upgrade Iocal ordinances. Thls pass-through money would underurlte the cost of hiring professional expertse for the tanis. and if each coastal communtty recelved $\$ 15,000$ per year not to exceed two jears, the total cost would be approxdmately $\$ 630,000$ over the two years. The state would continue to Implement thls aspect of the program unt1l such time as Indivit unl communtties had its local ordinances brought up to the seate standard. Compliance with the standards would be enforeat through a combination of local techniques and continuatton of the extoting "Cease and Desist Order/Orders to Remove and Restore" techntque utillzed by the CRMC. Thls optor would be restricted to the landside of the coastal. regton where local furlodiction is clearly established, thereby 
alleviating the furfadiction hodge podge that presently exclsts as a result of the 200-foot zone created by the RICRMP. The State Program would retaln paramount authorfty over phyalographical features and tidal waters. If federal funding ts cut to the bone, then this recommendatfon wiI lose its financial incentre.

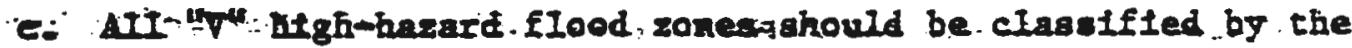
RICop as geographtcal areas of particular concern, not just the barrter benches as presently establ1shed, and to extend to ther: the spectal developnent controls now exercised and those conterplated for barrier beaches.

d. The CRMC should advance its position that it has statutory authortty over all physlographlcal features and can, therefore, establish whatever spectal area plans, permissible uses and development standards that are required to manage these these fenturea in accordance with the goals and the polfctes of the RICRMP. Thls Includes preempting local zoning control over the state's barrler beaches. If, however, total state control is exerelsed over the barrlers, the state mast be prepared to fulfitl the role performed by the local bullding inspector. Thts can be accomplished through the use of the profenatonal engincering staff now amployed by the Coastal 


\section{B. Overall Management Procedures.}

\section{Plndings.}

a. The Rhode Island Coastal Resources Management Program has falled to produce a resources management plan and grocess that is predictable and efficient. It has negIected to develop sufficient operational procedures and declalon-making criterla, and frequently fgnores the fer such procedures and criteria which are in place. The cruc is presently bogged down in the minutlae of trivis, Eratracide, I and polfticization of cases to the deeriment of overall resources plaming and management and attention to mafor 1ssues. As a result, there is an unnecessary cost to the state and applicants; and it has Ieft Implementation of the "burden of proof" requirements to an at hoc process which places most of the burden on state professional staff, the reverse of the legislative mandate. The lack of a plan or set of spectal area plans wth permissible uses and standards causes the CRMC to mite the same fundamental decislons meeting after meeting or routhe cases, while creating havoc for some controverstat cases.

b. The number of public bearlngs on projects needs to be redreed. In caleodar jear 1980, more than 80 applications recetved hearings. Thts annual total has dramatically inEreased each year since 1978, the year of Section 306 approval. In 1928, 30 heartngs were held, whlle in 1979, the number Increased to 42-an Increase of 40 percent. 
The actual increase of 1980 over 1979 is 102 percent. At an estimated $\$ 600.00$ per heartng, approxtmately \$50,000 was spent on public heartogs 10 1980.

c. Pablic hearings as presenty held on every iftele case produce Iftele information in addition to that collected through the normal 30-day notice perlod. Thls is predominately because by the time an applicant reaches the stage where a CRec assent is required, all other approw als, fncluding local zoning and subdiviston approval, and atate ISDS and Wetlands approvale, bave been secured. Cunges in the progran in accordance with $\mathrm{A.2a}$. and B2a. wII reduce the hearing cost by at least a factor of 10 . Eearingsshould be held for mafor cases as defined in Chapter 3, Section E.

d. The present process results in unecessary dealys. The 30-das notfce perfod 18 umeceseney for most profects involving construction of single-famtly dwelling untes, new fodividunt sewrge disposal systems, accessory structures, repatrs to bufIdings, porches, garages, patlos, greenhouses, decks, septlc system repairs, vegeeable gardens, ete-5 because an applicant in assured of CaMC approval if - -20

pione are cublited, all othar approvale have been securad, $\$ 35,00$ fillng fee is patd, and a perlod of 45 to 60 dage or wore 18 mited out. Changes in accordance with I.B.I. and II.B.I. and 2. wII otnimize the watting perlad by allowing state approval to occur wh whout the bene- 
out Involvement of the Council. The staff is the source of these stipulations and rather than put routine perafted projects out to notice, they can be handled alwost on the spot by the staff. Thls is especially perteineat afnce the RICRMP has become heavily frvolved in attempting to regulate activities within 200 feet of the mean high water and/or physlographic features. But since the anture of this regulatory effort is rarely a "use" zegulation as opposed to site impact mitigation, there tis earely nacd for a 30-day notlee pertod.

8- From 1969 to September, 1979, the application rate for atngle-fandly dwellinge and ISDS was 16 percent of the toeal case Ioad. Thts percentage Increases if the per- tod conmlned ts changed to 1975 to September, 1979, when it them became 20 percent; and, if measured from Uny. 1978, the time of 306 approval, to Seppember, 1979. the rate ariled to 38 percent of all applications. Fron Deember, 1979, until the end of September, 1980, the rate wis 55 percent of the case load. And during the perlod fron July, 1979, through August, 1980, 53 percent of the Intera of No Obfection Involved single-fanily drellings and/or ISDS, or acceseory atructures.

1. During the I4-onth persod, July, 1979, to Angust, 1980, the Bracuelve Director of the Curc Isaued 102 Ietters of Ho Objector- Examinetion of these casea reveals: (I) there is no pawelty of examples where profects fall- 
Ing under nearly all categortes of activity have been sent out to the 30-day notice perlod; (2) some, but nowhere near all, have stlpulations attached governIng one or more aspects of the project, such as its the frame or slte impact mitlgation procedures; (3) too mang are so loosely wrtten as to convey to the reader absolutely no 1dea of whst project 18 recelvIng the letter, and while thts information is supposedIf avilable in the file at the Divistor of Coastal Resources, It is basteally a blanik check to the rectpefint and bre reanlted In program devlations; (4) not al letters durfing the sample had a turn-around time that would fndicate as advantage of the "Ietter" vs. "the notlce" if mesured by time alone, because cases can be documented involving more than 30 days to get the Ietters out. The same problems have been observed for Cares and Destat Orders.

The Letere of No Objectlon has evolved as an admintstrattre device to deal ofth profects that clearly do not require CBMC review under current procedures. But cr1terta for lssuance of such letters and procedures governis sols thetr use are weak or noneadstent.

L. The carc consistentIs mygnores" the advice of the profeastonal staff. Ints often resulte in the wate of extengive ataff reviers of projects. 
j. The CRMC, by pursuing the minutae of regulation has lost the foltlative or the opportunity to capture intefative in the very 1sgues one would assume it had responsibility for: Upper Bay Quality problems caused by the Provldence sewer treatment factilty faflure; use fees for state waters and bottom lands beyond LHT, particularly where filling occurs or is proposed; examtnation of alternative courses of action for controlifing deveitopment on barrfer beaches, such ac more atringent setbacks, combloting lots, acquistfion rechniques, ece., rather than pursuing nonproductre verbeI assaults on the Federal Flood Insurance Program. 2

1. Stnce September, 1977, the GRMC has met twice per month in "Polfcy and Planntng Meetings," a practice carried on Gon the Program Development phase. However, in the exes yeara afnce the RICBuP was adopted, the more than 72 polfer and planoing compittee meetings provided not on addiefonal finding, polley, or regulatory amendment to the RICRMP unt1I January, 1981. During those three years, the cost of those meetings, not counting clerfeal etenff, Iegal fees, and adleage, is estimnted at $\$ 50.00$ par che naber par an average of seven attendees per meetIng or approximntely $\$ 25,000$ in salarles to mombers alone. yonthIt wileage costs accrued from attendance of all CRMC Detinge per wonth is constderable if one considers a II 
the opportunities encouraged by the Counc1i: attendance at public hearings, policy and planning meetings, monthly meet1ngs, rights-of-way subcommittee meet1ngs and hearfngs, atanding committee meetings and site flsits.

I. Under the present operating procedures, the Program captures aspects of subdifision construction, such as installation of roads and dratns and after the normal 30-day roview procesa, an assent is lssued for the work or a lettar of No Objection is 1s8ued in less than 30 days. This approval contains atte Impact uftIgat1on procedures. Inder these procedures, all house Iots withln the CRMC's perview must then be revilewed individually, on a case-bycase besis, whether it lovolves one lot or many lots. This drives up the administrative costs and the costs to the pubIfe. It IIlustrates a lack of predictability of the Program, whtle It fails to provlde assessment of the full inpect of the entire development because it is focused narrow If In the case-by-case dectsion-making process.

\section{Recommendat1ons.}

a. The atate needs to develop standards and/or procedures to cereen out whet should go bafore the Coastal Resources Ymagement Cometl and whet can be handled at the staff Ievel, as recomanded by the Prospectus in 1971. With the proper placement in the BICRMP, permtsatble uses and atendarda gutding developwent in accordance with A.2.a., 
cases not Involving use changes should not go before the CRMC. This includes cases involving allowed uses on barrfer besches, affecting other physlographic features, and below man high water, all of which should be handled at the stafe leveI, thereby freelng the CRMC from the case-by-case material to direct Its attention to larger Isenes of resources allocation; termlnate or reduce pol1theiration of cases; cut appitcant delays; and pare state opcrations costs.

b. The Gruc could become, under B.2.a., a planntng and hearfing body. It would be responstble for the maintenance of the RICRM, and whatever modifications or new flndings, polfeles, and regulations are required to that document. It would hear cases out to publtc hearing. It would adopt an admintstrative appeals procedure. Denfal of applicatons at the staff level and at the admintstrative appeals IeveI would be appealed to Superfor Court, as now dome.

C. In those cases where the appllcant must fulfill burdens of proof obligations, the CRMC should seek professlonal asalatance, elther at the staff level or from an Independent and qualffled source or both, to evaluate the ev1dence presanted by the applicant: Thts is presently not done or an routtne basis begond a crose-examination method which falls to ensure that the CRuc asks the: proper questons, or recelves valld information. To do this with the present hearing case load would be too costly. Under 
a reallstic case load of "major cases," this would make sense and work to preserve the integrtty of the process.

d. II those cases that must go out to public hearing, the bearteg should be presided over by a hearing offlcer, rather than three CRMC members and legal coumsel.

e. There are tro methods avatlable to reduce the number of public hearlngs. Plrst, change the unirltten CRMC polIc) that gdves all Councll nembers the power to call for pobific heartage on any applicaeton. Thls should be done bs adopting. written procedures governing the use of this optcon and providing the staff greater opportunity to work wth the public on projects that need modification to meet the requirements of the RICPMP. Second, strengthen the RICiuP's approach to uses, recogatzing the preminence of local zoning, but clearly stating areas of state control. Thts ackowledges the fact that once an Indfvidual has recefred all necessary local approvals, and is not in conElfet with an assigned use and standards established by the stece, the orly grounds for objection is bona fide evidence of enviromental degradatton of things that the etate does control, or conflict with the plan. The perIastble uses and standards of the PIan would serve as the cereanting exIterls to conble the staff to accept or refect objections. Objectors tho feeI they have been aggrieved can petiefon the Admintstrative appeals process or Supertor Court. 
f. The Council's regulations governting development on barrler beaches need to be refined with regards to treatment of buflding elevations, and the Council should take cogaizance of 1ts cule-making. Sectlon I30.0-2A2 of the RICRMP requites an additional 6foot eIevation of the Iowest structural members of the lowest floor (above the elevation established by the Flood Inswrance Bate Kaps). This regulation appIfer to oll barrfer beaches. The FIRM mape do not unformity treat the barfler beaches. The barflers. in Narragannett, South Ringstown, and WesterIs are d1rided Into "q" (veloctty) high hazard zomes on oceanm alde and "A" zones (not subject to wind driven waves) or the pond side. In Middletown, the barster beaches are completely designated as "A" zones; In Charlestown, the beaches are completely in "V" zones, while Iftele Compori and Mer Shorehar have undestgnated barrfer beaches becanse the towns are not in the regular flood insurance program as established by the Flood Insurance sdinfistration. The Cometi has taken to Issuing assents for dweIllngs on barrler beaches, contrary to adopted regulation governing the elevation of such structures, becawse of "extenneting" clrcumstances, which appear to be: (I) allowing dwelling elevation to conform to surrounding dralling elevetion, rather thm adopted rules; (2) arguwents that the RICRP barrfer besh regulations don't appIf to "A" zones on barrler beached (even though they 
clearly do); and (3) because "all those dwellings w11 take a slelgh Fide no matter how hlgh they are elevated.

8. Cease and Destat Orders should be fsaued only when there to clear adverse 1mpacts on physlographical features, water qualfty, enviromental degradation, or conflict with CRMC plans or standards. Whenever approprlate, Cease and Destst Orders should be accompanted by restoration orders wich afix a reasonable time perlod for compllance. In thoce crees whe there extsts potentlal adverse envirooanterl degradattor, the staff, acting on behalf of the Gax, should bave the capability to order immedlate site Impact mitigation procedures. A11 Caase and Desist Orders should be clearly worded with the spectfic asture of the violation.

15. The cruc reede to adopt a greater publtc advocacy rule for the nongenent plan. In doing so, the CBhy should becon an advocate for Its Program v1s-a-Vls the recoureed management 1seues. Thts type of effort would balance the largely public relations effort that presently creates a "indis Image" that does not extst in renIfty.

1. Interre of lo Objection and Assents should be algned by the applicent to ensure a better understanding on the part of the rectplents of the condstion of approval. Wht Ie this would require applicante to pick up the ap- 
provals in person, it may serve to reduce the number of assent vlolations that occur each gear. The use of the term "Letter of No Objectlon" should be abandoned in favor of constant use of the term "Assent."

1. The CounctI should adopt "one-stop" permteting procedures for subdivision reviews. Ttilizing the recommended development atandards, all physlographlcal features can be protected and reter qualfty protection stipulattons can b. Inoued on the entre plece of property. The selpulaelowe coutd be efther recorded wh the subdifiston at the Ioeal Ievel or atrached to the property deeds for each Iot. Enforcement would oceur as it normally does, through the fleld monttoring process of the staff with perhaps an added boost of assistance from local authortiles if given the pecessary tncentives and legislation.

5. The present computer gystem should be abandoned. Ideally, - new machine based record keeptog syatem to needed, and ali case Ioad information should be coded in by location fdeatefee and by named of Individuals, rather than by names and flle numbers. Stralghtforward T.S. Census Buran Ioeatior Identiflers can then be used to refer to sites andif even when property ownership chenges. This is imporeme for ascent rencuals, for determinting the legality of exdater factiftes, and will be absolutely necessary if a lane fee grotem ts tolthated. The location Ident1fler. wher kyed to project types, can factiftate data 
aggregation by geographic areas and by coastal waterbodies. None of these features are presentIy avallable.

I. In those Iaadside areas where the CRMC shares furisdicEor wth Iocal government, the Counctl should abandon tts polfcy of betng the last stop in the permitting process. By going before the local bullding inspector, the local goverment would have the benefit of the state's techntcal creluation of the site and the development standaxds that apply to $1{ }^{5}$ This should be a leglslated requifrement, and it ahould apply to site work as well as othere consruction.

I. There bas been a constant public concera about the qualfty of appIfcations, partlcularly regarding the Informstion they contafl and the work they propose to accompligh. This attuntion can be handled correcty only with a clear cometation of the requitements and by exerclsing greater attenton to detail at the appropplate staff level.

D. The Cownet has beer found by the Courts to exercise too mech discretion in 1 tes declsion-maktag process. Aloo, the bordens of proof requirements of the management progro out of contert. The leglolative context requires the the couc establlat the-fifghes and best we of the towd and water resources under 1 ts jurladiction, through - resources capabiftty and planatng process that creates ac an end product a management plan with standards and 
criteria. In thls context, the burdens of proof proFiston of the program makes considerable sense. Areas of the coastal reglox clearly sensitive to development pressures of particular types and those areas especially attractive to development and capable of supporting it through the natural and man-made environment would be clearly enunclated maktng the burdens of proof more than an obscure facet of the program. The process now serves to syggec burdens of proof that have few firm avallable manures. Ints recom nendation to made in accordance with 4.20. and B.2n.

\section{Osganizactor.}

\section{Findings.}

- The Givc's compoattion appears to be in Flolation of the spirlt and probably the letter of Its statutorily mandeted rule of two: Rot more than two members will be from ary ono community. The Town of Narragansett has three mambers on the Councll: a Iocal resident, a town counc1Ianc and acate representative.

b. The Chatrmansip and position of Bxecutive Director of the Cauc are held by the ano Indfoldual. This is an

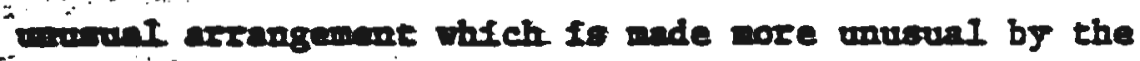
propeartity of this Indfridual acting as Brecnetve Director to becone persomelfy lovolved in pearly every case. This perforifis of staff level function results in 400 to 500 afte Flates amonify, often in the company of the 
Division of Coastal Resources Chlef and produces no substance on the record which w1ll assist either the staff or the CRMC in the dectsion-makting process. It also detracts very serlously from the time and effort spent of traditfonal erecutive drector-type functlons which involve policy work, problem solving, advocacy of the organization's positions vis-a-vis 1ssues, Intergovermental contact and coordination at the problem colving Ievel, Ieglolative Ifatsor and Inftiative, and genexalI strong Ieadershfp at the froutlers of coustal resources mangement, rather than being mfred into the day-to-day operations.

c. Seven of the seventeen GRMC nembers bave served on the Counct alnce its inception.

\section{Becommendations.}

- The atatutorify mandated rule of two needs to be stcletly enforced to enswre proper consistency representation; the appointefng powers should remedy thts tmbalance as soon as posstble.

b. The Chatrmanblp and Executfre Director positions need to be separated. The Counctl should have a role in vilecting the endidate for both postetons. ConsiderIng thre the present Execuetve Difector perform "staff Ievel work," it is questlonable if such a posttion to neceseary. If tt is necessary, there aceds to be criterla 
for the Execuftve Director's positfon which should Include professional certification; experience in source management; clear writting and speaktng ability as denonstrated through education and experfence, and to borrow an informal criterla from the Rhode Island State Department of Economle Development, should be a now-Rhode Island restdent.

6. The tarme for Councti membership should be legtslatively reatricted to one two-to-four year term, and greater inInd commity and atate agency representation should be nandated but without fncreasing the number of wembers.

d. The state shoild consider organtzing its coastal managenant staff along more functlonal lines, that is assignIne persomel to cover spectflc types of projects, such a. If rat proposals, aqueculture profects, port developnut, mafin development, or for spectfic phyalographical featuress auch as barrler beaches, coastal marshes, coagear poods, and entuarles. These persomel would be recognized as experts in thetr field of spectalty and would partlclpate as witi-disciplinary team whenever necessary. Thts recom medation to made neceseary because the CRuc's procedures for developter ax "evidentelars base" for dectclons aphasises "expert testimong" whtch on occaston has Ifoparaged ataff because of a Iack of a particular acereafenctor:

$\cdots$ 
1. Coastal Resources Management Counc11, IBANSCRIPT, November 13, 1979, P. 11., Pp. 101-102; January 8, 1980, p. 71, Pp. 8385. P- 91, P- 10I; March 11, 1980, P- 19, p. 23; April 8, 1980, P. 34; May 13, 1980; pp. 7T-82; MAY 27, 1980, PP. 2627: August 26, 1981, p. 68; September 9, 1980, p. 31; September 23, 1980, p. 20; Octoter 14, 1980, pp. 32-34; October 28, 1980 , p. 39 .

2. Interestingly, It was reported in the October 26, 1980, Prov1dence Sunday Journal that the CRMC Itself spurred development on the Rhode Island Barriers.

3. Rhode IsIand Department of Admtatstration, Divialon of Accounts and Controle, Statement A and Statement C for pertod July 1, 1979. to Irme 30, 1980, and monthI' statements from JuIy I, 1980, te. Unes, 1981 .

4. The BICRuP, Appendix B: 4.I(5) provides that "gatd formal written obfection and/or request for hearing 18 substantiated by genutne and matertal reason therefore." There 1s, however, no admintstrative procedurest to determine if an objection is "genulne and tacestat:"."

5. Bdward A. Thoma, D1v1s10n D1rector, Pederal Insurance Administraton, Boston, Letter to John A. Lyons, Chalrman, Coastal Resources Kanagement Councll, undated. Beference to Donald R. RIdd, File 79-4-15. Lee B. Whitaker, Division of Coastal Resources, Letter to Victor Parmentler, Supervising PIanner, Phode Island Stateride Planning Program, November 25, 1980. 
When a man knows he is gotng to be hanged in

a fortoight, it concentrates his mind wonderfuliy."

- Unimown 


\section{EPIIOGUE}

The RICBop while often descrtbed as one of the best in the natox, and whose Ieglolative mandate 1s sometimes (questonably) referred to as a "model" for the federal statute, is not working well. It certainily is not performing as the early framers of the state's legisLattre base had wanted it to work. It Is clear that the program's fallfngo are a result of an urrealistle management approach and the properefts of the Che to Ignore apectfic programate requirements whenever

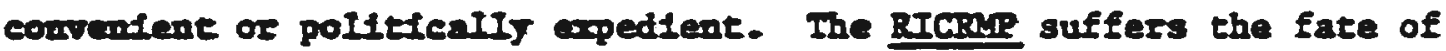
mang Eraditfonal Planoting documents-it is Ignored.

It ts clear that while program success can be enumerated through succesefuI court casea and dectalons, denying sowe of the worst of the proposed development projects that would affect the Rhode Island Coastal Beglon, It 1 s also clear that mafor inconsistencles and straightformad tmbftiteted cint: that the overall operating cost to taxpayers and appIfemte are uncescartIy high; and that the program has falled to focurc on and acturily solve probleme.

One corrective action angested by the caseload and analysis and the workebop held Jamung 29, 1981, Is to witch to a sectal planntag

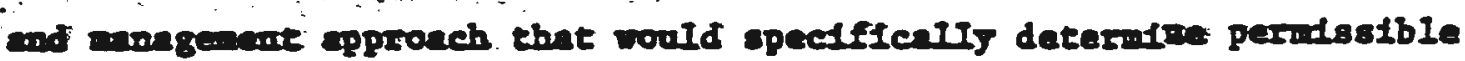
wees, probthittons, and devetopment standards. Thlo would aees to be are reallate than the approach which now broadis appllas the ame spectefe regutattow and burden to screral diseimilar areas, regardlese of how valtd or ofintiar the goets sought are for these arens. 
The Councli's role would be that of the responsible public body to maintain andupdate the plans as necessary. The CRKC presently has the statutory authortty to achleve this.

Agsfieved partied to the plan would have admintstrative recourse to an appeals board or hearing body and/or solely to the Superlor Court. This mechantsm is not fully provided by the present enabling Iegislation and it is not knom what the chances are for this change. The Council members, who are not ofthout power, collectively and IndiFiduilly have a veated faterest in not changing the syatem so dramaHeally. Ints concluaton is based on the fact that they bave resiated for years the resource base or apectal ares planning and management concept with the unsupported argment for "flexdbility." However, the tIme for change may be at hand.

The 1980 federal CaMA reauthorlzation b111 (B.R. 6979) had to be scheduled on the suspension calendar because it fafled to reach the floor of Congress under the rule. The bill passed the U.S. House of Representative at 9:43 p.m. on September 30, 1980, and the Senate at I:08 a.I. ox October In 1980. It barely made it under the wire at the start of the federal flscal year. Inla was a wark of things to come.

1. research for thls paper was betng prepared, the Reagan AdutnisEation intelated budget cutelng that will have a profound lmpact on en-

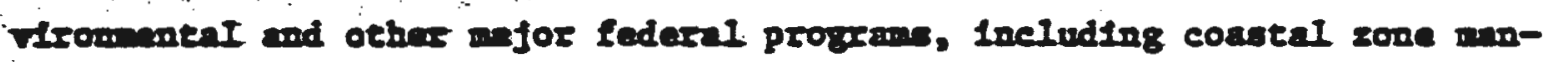

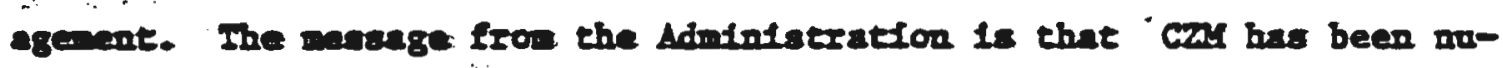
tured by the federal goverment, and if the expertment bas any value, it should be celwefvely supported by state and/or local goverments. 
The budget reductions planned in early 1981 foretold a cessation whth 15 months of all federal financlal support for the Rhode Island Coastal Program. This will represent an annual loss to the state of one afIIox doIfars, and If coastal managemant io Bhode Island continues as te bas during the past three jears, state tar dollars will be required to plck up the slack. But because the Reagan Adminfstration is cutetng other federal programs as well, the loss of federal revenues to the state WII be many milfon of dollars, thereby creating Intense competition at the state Ievel for whrtever tax revemues can be raised.

Into paper has revenled that the Coastal Mnagement Program in Bhode Intond he amber of operatlonaI and basle programmatic flaws. Indeed, ore Is hard pressed to discover what difference the program has made in Bhode Island, that has been worth the expendlture of more than $\$ 4.5 \mathrm{mt1}$ Iton federal dollara- The logtenI extenston of the Councti's argument -that the Cruc must be practical, pragmat1c, reasorable, or bowever else one can exphendstcally describe the practice of disegarding adopted poltctes and regalatione is to throw the "management" of the publte resowee beck to Individuats acting individually with no concern for the overall vilue of the resource or overall outcome of thedr manp separate actions. That is, why have a CounetI at all tf its actlona are producing an end product that differa very Iftele from the end product obtainable through a pure Intacas-fatre gatemt

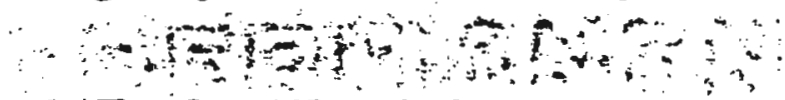

The-comeit and the prograin personat have not been unware of the progran's dfffenItles, and work bax been underway alnce late Antum, 1980, to overeom the. Identffing the Program's Inherent flars has bean difficutt and Ienato unetted. The effort has easentially as- 
sumed the scale of a total rewriting of the RICRMP, and as the state's coastal management personnel become more deeply immersed in the complextthes of this task of reexamining the claselflcation of coastal waterbodies, the definitions of permissible uses, the preparation of, hopeEuIIy, spectal ares plans, the preparation of standards to accompany the permissible uses and the redesignation of Geographic Areas of PartIcular Concern, progress why $=h$ always appears to be painful in government, wII certainly be slow.

It th the hope hare that?thts research project will lend 1 tself to the programetie reevalustion now occurring by polnting to those plefalls thet beve trapped Bbode IsIand in an overly expensive and not so effective paper pushtng management program. Not surprlstigly, the spectre of federal budget cutting has acted as a powerful atlmulus to program reform. However, whatever faint hope there may bave been that federal oxeralght would prevent or correct programmatlc devlations, w11 become no hope whtever. The task wilI fall squarely on the state. Durfng the part three jears the orIy force vithin: the state for attempting to ensure program conststency has been the federally funded personnel. They ware not always succesaful, but with the federal cuts threatenting to elimInate neariy all personnel, except the CRuc and 1ts Iegal staff which are state funded, the one internal force for conslstency will be dectmated, throwing the responotbitity to cltigen and the court syotem. 


\section{BIBLIOGRAPHY}

I. Amato, Richard J. and Whitaker, Lee R., "Rhode Island Coastal Commuity Land Use Review: A Study of Resources Allocation in the Coastal Communty," Resource Allocation Issues in the Coastal Environment, Arlington, Virginias Coastal Society, November 6-8, 1978, Proceedings; 130-152.

2. American PIanning Assoctation, "Research D1gest," PIanning. Vo1. 46, No. 9 (September, 1980): 24.

3. Beattie, James T., Chtef, Division of Coastal Resources Department of Environmental Management, Interoffice Memo to Coastal Resources Management Counc1l Members, October 19, 1979.

4. Brooks, Rtchardi and Payne, Remeth, et. al., Presentation of Audubon Soctety of Rhode Island. The Natural Resources Defense Counct1, Inc., Ecology Action of Rhode Island, Inc., Conser-

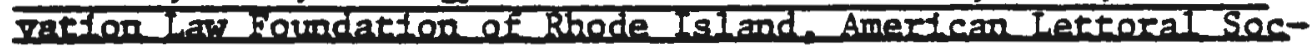
1ety. Inc. Before the Rhode Island Coastal Resources Manarement CounctI, July 26, 1976, State Bouse, Rhode Island.

5. Buerle, David, State of New York Department of State Memorandum to Hank Williams, on Federal CaI Threshold Papers, January 22, 1976.

6. Chasis, Sara, "The Coastal Zone Management Act," JAPA. Vo1. 46, No. 2 (Aprt1, 1980): 145-153.

7. Coastal Resources Center, Dntversity of Rhode Island, A Compllation of the Polfictes and Regulatlons Regarding Areas and Activities Above Mean High Water Contalned in the Rhode Island Coastal Resources Management Program as adopted in September, 1977. KIngston, Rhode Island: undated.

8. CoantaI Resources Center and Resources Management Systems, Inc., The CoastaI Resources Management Program: A Handbook for Permit Applicants, Jure, 1978.

9. Coaseal Zone Management Inprovement Act of 1980, H.R. 6979.

10. Colnm, Steve, Hew England RIver Basins Commission, Coastal Zone Task Forca Ifanton. Memorandun to New Bngland/Ner York Coastal Zone Iant Poree; December 12, 1980.

II. Counine, Ififtugr, Northeast Reglonal Coordinator, Office of CoastaI Zome Mragement. Latter to Stephen 0lsen, Coordinator, Jatverafty of Rhode Island, Coastal Resources Center, December 28. 1976. 
12. Evans, Charles H., Environmental Analyst, Connecticut Department of Environmental Protection, Letter to John Sun, February 2, 1976.

13. Frfeden, Bermard J., "The Consumer's Stake In Environmental Regulattou,". The Annals., Vol. 451 (September, 1980): 36-44.

14. Geremia, Frank, Assistant Director of Operations, Rhode Is land Department of Environmental Management. Volume of Paper Memorandum, December, I980.

15. Grant, Malcolm J., "A Brief and Crltical Look at Coastal Resources Management on the State Level." Prepared for the University of Rhode Island Coastal Resources Center, Novemoer, 1972.

16. "Burden of Proof and other Demonstrattons," Memorandum, December II, 11979 .

17. Lacter to Jack Lyous, Al Goldman, Denny Esposito, Dan Varln, Eee Whttaker, Steve OIsen, September 14, 1976.

18. Procedural EvaIuation of the Rhode IsIand Coastal Resources Mamagement Program: Recommended Improvements. Hope Valley, BI: Resource Management Systems, Inc., February, 1980.

19. Rhode Island Position Paper on State ObIlgations Onder Section: 306 CaMA; State Response to Those Obligations., September. 1976.

20. Hunsberger, David H., Survey of Coastal Zone Permft Information Systems, State Visit Report: Rhode Island, Draft for Comment, Frepared for the Offlce of Coastal Zone Management, December 17, 1979.

2I. Tellar, George, An Approach to Application Evaluation, Ringston, Rhode Island: DnIversity of Rhode Island Coastal Resources Center, November 29. 1972.

22. Rneche, Robert W. Fladings of Robert W. Rnecht, Assistant Administrator for Coastal Zone Management, National Oceanic and Atmospherle Adminlstration, Approval of the Rhode Island Coastal Mamagement Program. Washington, DC: May 12, 1978.

23. Errecht, Robert W., Asalstant Adminlstrator for Coastal Zone Manage$\because$ ane, Latter to John A kyons, Chatrman, Rhode IsIand Coastal $\therefore$ Besources Sanagement Counct1, September 14, 1976.

24. Larage, W.E.R., President, Narrow Rfver Preservation Association, Ietter to John A. Lyons, Chatrman, Coastal Resources Management counctl, February I4, 1980. 
25. LaRoe, Edward T. and Roy, Elizabeth Sheiry. "Federal Inconsistency: Administration of the CZMA in the absence of Explicit Federal Policies and Standards," Resources Allocation Issues in the Coastal Environment. Arlington, Virginia: Coastal Society, November 6-8, 1978, Proceedings, pp. 9-23.

26. Lee, Virginia, An Elusive Compromise: Rhode Island Coastal Lands and Their People., Ringston, RI: Unfversity of Rhode Island, Cosstal Resources Center, 1980

27. Ifnk, Charles W., BuiIding Inspector, Town of Charlestown, Rhode Island, Letter to Rhode Island Coastal Resources Management Counctl, January 16, 1980.

28. Lyons, John A., Chatrman, Rhode Island Coastal Resources Managewent Councll. Letter to Robert Rnecht, Assistant Administrator for Coastal Zone Management, August 19, 1976.

29. Latter to Governor I. Joseph Garrahy, Jume 28, 1979.

30. Letter to Leo R. McAloon, Jr., Governor's Office for Coastal Zone Kanagement, July 19, 1979.

31. Letter to WiIliam Carroll, Executive Assistant to the Governor for Polfey, July 25, 1979.

32. Letter to Governor I. Joseph Garrahy, August 9, 1979.

33. Letter to Adrian Golman (sic) and George Sherwood, November 29, 1979.

34. Letter to Daniel W. Vartn, Chief, Rhode Island Statewlde Planafing Program, December 18, 1979.

35. Leter to Robert A. Weygand, Secretary, Bast Providence PlanIne Board, March, 13, 1980.

36. Letter to George Favre, Ed1tor, Bditorlal Department, Providence Jounnal Company, September 15, 1980.

37. Letter to Ramon Pema, Governor's Office on Coastal Zone Management, September 29, 1980.

38. Notlce. Jume 26, 1980.

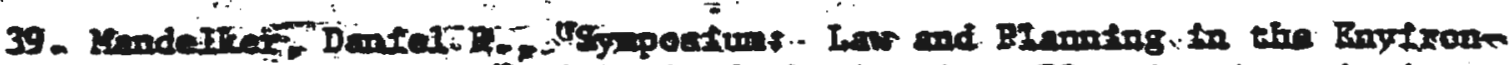

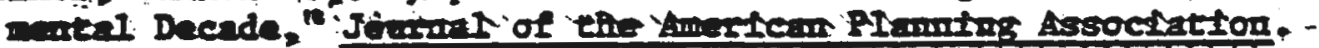
GINA) - VoI. 46, 10. 2, CApIII, 1980I: Pp. 133-134. 
40. Murphy, Dennis T., Director, Department of Natural Resources, Letter to Lee R. Whitaker, Rhode Island Statewide Planning Program, January 31, 1975.

41. McDevitt, Joseph T., Executive Director, Rhode Island League of Citles and Towns, Statement prepared for the Bearing on the Coastal Resources Management Plan. March 20, 1975.

42. NaturaI Resources Group. Report on Administration of Narragansett Bay. - Providence, Rhode Is Iand, January 1, 1969.

43. Office of Coastal Zone Management, Draft 312 Evaluation Findings for the Rhode Island Coastal MAnagement Program Covering Grant Perlod from January 1, 1979, to December 31, 1979. Washington, DC: Apr11 7, 1980 .

44. Evaluation of the Rhode Island Coastal Management Program for the Grant Perlod from January 1, 1979, to December 31, 1979. Washingtor, DC: June 6, 1980 .

45. Sectior 312 Findiggs, Evaluation of the Rhode Is Iand Coastal Management Program Covering the Grant Perlod May, 1978 February, 1979. Washington, DC: Apr11 19, 1979.

46. Olsex, Stephen, Coordtantor, University of Rhode Island Coastal Resources Center. Letter to Grant, Lyons, Esposito, Whttaker and Zettein-Hale, November 23, 1976.

47. Letter to Kathryn Cousins, Northeast Regfonal Coordinator, Office of Coastal Zone Managenent, December 3, 1976.

48. Memorandum to Invitees to the January 29 Coastal Resources Mnagement Program Workshop," Pebruary 16, 1981.

49. OIsex, Stepheri and Lee, Virgdnta. A Summary and Preliminary Evaluattor of Data Pertaining to the Hater Quallty of Upper Narragansett. Bay. RIngston, Rhode Island: Unfversity of Rhode Island Coastal Resources Center, May, 1979.

50. Parkhurst, J1m, Rhode Island Coastal Resources Management Counc1l Blologist's FleId Report on Falvey, August 27, 1980.

51. Rhade Island Coastal Resources Management Council Blologist's IteIt Report on Gallahan, March 30, 1981.

52. Peane, 11Iex, Drrector,. State Plaming Offtce, State of Malne. Lettex to Wr. John Sum, Northeast Regloual Coordinator, U.S. Department of Comerce, Natfonal Oceante and Atmospheric Adminis7 tration, Offtce of Coatal zone Management, February 5, 1976.

53. Pease, James R. and Morgan, Mchael. 'Performance Zoning Comes to Oregor," Plaming. VoI. 46, No. 8, (August, 1980) = pp - 22-24. 
54. Pisani, Nicholas A. Rhode Island Coastal Resources Management Council Engineer's Field Report, November 1, 1979.

55. Pisan1, Nicholas A. Civil Englneer. Inter-Office Memo on Goldman and Sherwood, March 11, 1981.

56. Poister, Theodore H., Public Program AnaIys1s: Applied Research Methods. Baltimore: Untversity Park Press, L978.

57. Rhode Island Coastal Resources Mamagement Counc11. Coastal Resources Management PIan. Provldence, RI: September 18, 1972.

58. State of Rhode Island Coastal Resources Management Program. Providence, RI: Spring, 1976.

59. Summary of Issues Ratsed at Beginning CRMC's Workshop, Nov ember. 29.1972.

60. Phode Island Department of Environmental Management, DIvistort of Coastal Resources, CoastaI Resources Management CounctI Draft Narcow River Palier Options- Providence, RI: June 30. I980.

61. Coastal Resources Management. Section 312 Program Review and Evaluation. Providence, RI: February 5, 1980.

62. Cosstal Zone Management Amnual Report for Figcal Year 80 , Providence, Rhode Island: undated.

63. Inventory of CRMC Cease and Desist Orders for Calendar Year 1979. Providence, Rhode Island: Jamuary, 1980.

64. "Log Bntries," November, 1979-AprtI, 1981.

65. "Staff Reports to the Coastal Resources Management Council," Coastal Resources Management Counctl Agenda, Providence, RI: Bebruary, 1980-Apr11, 1981.

66. Thode IsIand Development CounctI, The Rhode Island Shore, A Regtonal Guide PIan Study, 1955-1970, Providence, Rhode Island: 1955.

67. Phode IsIand Statewide Planning Program. Program Prospectus for the Coastal Resources Management Counc11, Provldence, RI; SeptemBer. 1971.

68. - State tand Use Polleter and P1an, Report No. 22, Providence, II 1975 . $\because$ in.

69. State of Rhode Is Iand Report of the Governor's Committee on the Coastal Zone. Providence, RI: March, 1970. 
70. 208 Water Quality Management PIan for Rhode Island. Providence, RI: March, 1979.

71. Senate Comittee on Comerce, Coastal Zone Management Act Amendments of 1975, Report of the Senate Committee on Conmerce on $S 586$. Washington, DC: U.S. Government Printing Office, 1975.

72. Special Legislative Commission. Final Report of the Spectal Legislattve Commission to Study and Make Recommendations Regarding Approprlate Fees to be charged for all Drivate uses of Public Waters and Other Related Regulations and Statutory Provisions, Providence, RI: February, 1981.

73. State of Rhode Island, Application for Section 350 Coastal Zone Management Program Development Grant. Prov1dence, RI: February 8, 1974.

74. State of Rhode Island. Response to the Request for Information Regarding the Third Annual "312" Review (1980) of the Rhode Island Constal Resources Management Program. Undated.

75. State of Rhode Island Coastal Resources Management Program. Providence, RI: March 14, 1978.

76. "The Admintstrative Procedures Act," General Laws of Rhode Island. Title 42, Chapter 35, Section 42 .

77. "The CoastaI Resources Mamagement Act of 1971," General Laws of Rhode Island, Tftle 46, Chapter 23, Section 46.

78. "The Shore Development Act of 1956," General Laws of Rhode Island, Ittle 46, Copter 3, Section 46.

79. State of Rhode Island and Providence PIantations, Coastal Resources Management Counct1. Meeting TRANSCRIPTS, July 10, 1979March 24, $198 I$.

80. State of Rhode Island and Providence Plantations, Providence, SC. Declston, John A. Lrons, et. als. V. Nancr Fillmore., C.A. No. 72-182.

81. State of Rhode Island and Provldence Plantations, Provldence, SC. Declston, Nams B. Fillmore V. John A. Lyons, et. als., C.A. Bo. 73-2373-

82. State of Bhode Island and Providence Plamtations, Supreme Court OpIntion, Ease Greemolch Yacht Club, et. al., V. Coastal Reeources Management Councll, et. al., No. 75-280 M.P., July 11, 1977. 
83. State of Rhode Island and Providence Plantations, Providence, SC. Deciston, Milardo $\nabla$. Coastal Resources Management Council, C.A. No. $77-735$, C.A. No. 77-2245, January 7, 1979.

84. State of Rhode Island and Provldence Plantations, Bristol, SC Dectsior, James Betres, et. als. V. Coastal Resources Management Council, et. als. C.A. No. 78-3858.

85. State of Rhode Island and Provldence Plantations, Providence, SC. Deciston, Dalmazto 0 . Santint $\nabla$. John A. Lyons, et. als. C.A. No. $74-3158$, C.A. No. 74-3159, A. No. 79-1162, May 15, 1980.

86. State of Rhode Island and Providence Plantations, Providence, SC. Dectstor. Clean Cove Committee, Inc., V. Coastal Resources Menagement Council, et. als. C.A. No. 79-1781, December 17, I979.

87. State of Rhode Island and Providence Plantatlons, Providence, SC. Dectsion, William Barnack $\nabla$. The Coastal Resources Management Counct l of Rhode Island, et. als. C.A. No. 79-3842.

88. Studds, Representative Gerry E. Chatrman, Subcomitttee on Oceanography and Pritchard, Representative Joel. Letter to the O.S. House of Representatives Committee on Merchant Marlne and FIsherfes. September 30, 1980.

89. Taf, Simon W. Soctal Science Statistics. Santa Mar1a, Calffornia: Goodyear Bublishing Company, 1978.

90. The Library of Congress, Congressional Research Service. LegisIative Btstory of the Coastal Zone Management Act of 1972, as amended in 1974 and 1976. Washington, DC: C.S. Govermwent Prinefing Office. 1976.

91. The Miamf Herald.

92. The Narragansett TImes Company, The Narragansett T1mes. Narraganset, Rhode Island.

93. The Providence Journal Company, The Providence Sunday Journal, Providence, Rhode Island.

94. The Providence Journal Company, The Provldence Jouraral, Providence, $\therefore \ldots$ Rhode IsIand.

95. The Providence Journal Coupany, The Eventng Bullet1n, Provldence,

96. Thomas, Edward A. Division Director, Federal Insurance Administrat10n, Boston, Letter to John A. Lyons, Chairman, Coastal Resources Management Councti: undated. 
97. University of Rhode Island, Coastal Resources Center. Unpublished paper on legal principles prepared for the Coastal Ponds Study.

98. Vartn, Daniel W., Chief, Rhode Island Statewide Planning Program. "State Coastal Zone Management Workshop, Airlle House, Virginia, November, 4-6, 1975." Memorandum, November 10, 1975.

99. Memorandum on OCZM Threshold Papers for 306 Program Approval, January 12, 1976.

100. Interoffice Memo to John A. Lyons, Chairman, Coastal Resources Management Council, December 28, 1978.

101. Letter to John A. Lyons, Chaiman, Coastal Resources Management Councll, March 20, 1979 .

102. Whttaker, Lee R.,. Comversat1on with Robert Frederlcksen, Providence Journal-Bulletin, Conservation Writer, June 21, 1979.

103. Personal Notes, CaM Workshop, Astlowar, California, May 27-30, 1975.

104. Personal Notes, Federal Office of Coastal Zone Management Site Visfts, Newport, Rhode Island: July 22, 1975.

I05. "Burden of Proof Requirements of the RICRMP." Interoffice Memo to I. Lyons, I. Beatt1e, M. Grant, December 12, 1979.

106. Interoffice Memo to John A. Lyons, Chairman, Coastal Resources Management Councti on the letter from the Charlestown Town ButIdtig. Inspector, Jamuary 18, 1980.

107. Whattaker, Lee R-. Rhode Island Department of Environmental Management, Divistor of Coastal Resources, Letter to Stephen B. Olsen, Coordinator, Unfversity of Rhode Island Coastal Resources Center, September 26, 1980 .

108. Letter to Stepher B. OIsen, Coordinator, University of Rhode IsIand Coastal Resources Center, October 2, 1980.

109. Letter to V1ctor Parmentier, Supervising Planner, Rhode Island Stateride PIaming Program, November 25, 1980.

II0. WIIson, BIIzabeth M.. Town Clerk, Letter pertatning to the Minutes of the Hecting of the November...26, 1979, South Ringstown Town Comet I veting.

1I1. Wootard, Reglonal W., CoaneaI Resources Management Project Director, New Hampshire, Latter to John Sun, Northwest Reglonal Coordinator, Office of Coactal Zone Management, January 20, 1976. 


\section{APPENDIX I}

\section{RHODE ISLAND COASTAL RESOURCES MANAGEMENT DEVELOPMENT STANDARDS}

These: standards, presentiy absent in any form from the RICRIP (with the exception of several of the outright prohtbitions and a reference to the Rhode Island "Eroston Control Handbook"), have been prepared for Incluston in the RICRMP from a revlew of 218 cases before the Coastal Resources Management Council from Rebruary 12, 1980, through urreh 10, 1981. The standards apply within the 200-foot 1nland jurisdiction Ifne created by the EICopP and areas of primary furisdiction (below mean bigh weter and physlographical features).

The reviev perfod contains a representative number and mix of profects that can be considered elther routine or controversial and that have recefved full Councll revlew. Because these standards have been attached to profect assents in the form of staff recommended stte-spectfic atpulations, they can be considered "fleld tested." They have evolved through the experience of nearly three years of continuous field evalustfon of profects by the same personnel funded through CZMA Section 306 grant monies.

As the Council moves to Iessen the admintstrative and paperwork costs of Coartal Resourcer Yanagement, It is recommended that the staff

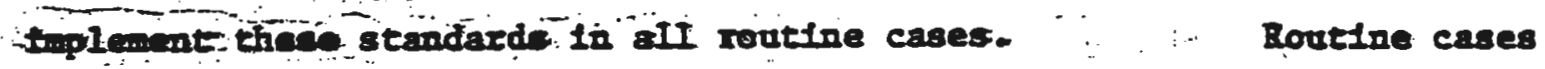
are those whtch are for permisetble uses, which do not confilct with the RIGopr, and wich do not trgger the burdens of proof requirements. It - Io aIsa anggested that the Councll give serfous thought to pursulng the 
leglslative inftlative of enabling all local comunities to adopt these or simflar standards and enforce them as a matter of routine polfcing of local development. Such local adoption would have the benefictal effect of lacrensing the public's kowledge of what is expected. It would also tmprove enforcement of the state's polictes to preserve and protect the Coastal resources. Properly adopted, these standards could be enforced by local butlding inspectors as well as state cosstal management personael.

The Ilst appears to be comprehensive, but 1 ts Iengthlness should not be viewed as a detrlment to the program or as a measure of toflextbfIfty. These standards do not apply in all cases, of course, as they are tallored to the s1te condittons by the staff. Moreover, they are not prohtbltive, nor are they laclusive. The provision for on-site mitIgatlor procedires by the staff is necessary to cover situations not provided for hare.

The appltereton of these standards is melghted towards undeveloped and nonurban aren becanes it is preclsely those areas where the preservetton and protection ethic of the program is most visible. It is also those areas where development proposals can be more eastly considered as routfine as opposed to mefor factlity development which could occur anywhere, but would be more likely to occur to an urban setting. Regardless of where anfor faclifty wolld occur, 1ts.1mpact on the sur-

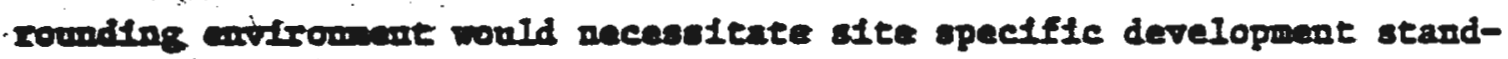
arde of a type whtch the Rhode Island Cosstal Program bas not yet developed expertence Ior. 
General Protection of Physlographical Features.

1. The practice of mowing marsh vegetation shall be discontinued/prohabteed.

2. There shall be na fiII placed on marshes or beaches.

3. Areas where marsh alterst1or occurs, such as through man-1nduced site alteration sedimentation 1mpacts, shall be restored.

4. The creation of anitmursh shall occur in another location to componnte for Iost mrsh, in cases where such Iose is unvoidable. (mite bie occurred for the construction of a new brldge abutwant whteh ftifed approsdmately 1600 square feet of marsh, and elsewhere, where alfgoments of man-made structures could not reasonabIs be altered.

5. Restiction to the use of rubber tire vehteles shall be enforced where work with machinery ox a marsh is unavoldable.

6. Pituce proparty atgne and chatn If fences, shall be probibited or basches and birrster beaches. $\cdot$

T. The use of apphalt peving ox beaches and barrter beaches and on marshes shall be prohibited.

8. The we of parabible surfaces sheli occur for drivewayo and park-

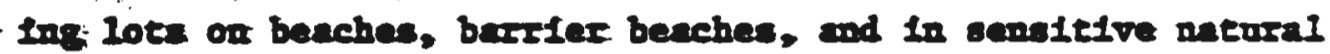
creas.

9. Grading, fliting or diaposel of debris and materials on dunes is probibtted. 
10. All excavated materfals in trenching work shall be placed on the upland side of the trench away from the sensitive natural features.

II. AlI work shall be monttored by the GRMC staff to Implement on-site envirommental controls as necessary.

12. The staff shall revles pro; ect controls with contractors prior to commencement of work. It is the obligation of the Contractor/Applicant to nottey the couc or 1ts stafe when a project is to cownenee.

RenIdenetal Construction, General Constructlon, Accessory Structures.

I. For ISDS or cesspool replacement, all Ifnes, pIpes or other connectlons to the orfginal, falling sewage disposal system shall be discomnected, removed, or ocherwlse discomected.

2. The Iower EIoor. Ineliding the basement, sbaIl be elevated to or above the base flood elevation as defined by the Flood Insurance Bate Mapa.

3. A Ifne of staked hay bales shall be placed between the construction ste and the weter or physlographic feature to control sedtmentation and absil be matntalned until proper vegetative cover is established.

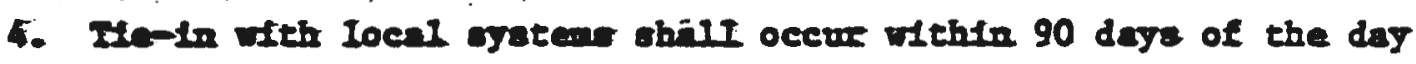
that sewers becowo operatfonal -

5. Devegetatton of the embankment leading to the shore shall be proHbited. 
6. A vegetat1ve buffer zone shall be established landward of the marsh, fringe marsh, top of bluff, seacliff, or embankment. Thls zone shall be staked by the staff englneer or biologlst prlor to construction. (Thts zone historicilly is tallored to stte conditfons and has beex as narrow as 10-feet and as wide as: 60-feet. The 50-foot zone is most commonly used. Ten to trenty-five feet is common at the crest of an embankment; 50 feet whenever posstble along marshes, 50 to 60 feet alone tops of elffe and bluffe. These are often considered to be winimal and argurbly should be grenter when condttlone wareane).

Tir Grading and fIIIIng activities shall not encrosch on the buffer zone.

8. MII cucese debrls and construction materlals ahall be properly disposed of at a auttable upland locatton, not in the buffer sons. the march, on the beach, or in the weters of the state.

9. Alf f1II and disturbed areas shall be vegetated as soon as posable (or covered with milch) to prevent erosion.

10. Bay balea shall be staked at the toe of the fIII and matntained whtl the fill is stabilized with vegetative cover.

1I. Foding ambentoments shril be restored imadiately.

12. In cecordance with the state's adopted 208 Water Qual1ty Managewe PIn, chomiente such ac ferefIIzers and pesteIdes shall be earefully and sparingly applled along sensittve natural areas wach as the Upper Narrow If ponde. 
13. Low flow water devices and prohibition of washing machines and dishwashers shall be 1mplemented where ISDS systems are Installed II dellcate areas (shallow depth to water table, coastal ponds, perhaps upper Iarror Bf(ver).

14. The atock-piting of fill and materlals shall be set back from the top of embaniments, edge of bulkheads, etc., 10 to 50 feet as stte condtetons allow.

15. Exeavettow and grading shall be rentricted to those activittes and rren: necesenry for the actual construction of the drelling, buildIng or Ists.

16. Hand excavation of footinga shall occur in particularly sensitive areas where: the use of machinery ts not only inapproprlate but not vitaII neceseary to eccomplish the work.

IT. PermeabIe aurface for drIveways, parkfng areas, ete., shalI be veflized whenever feastbIe, espectally in senaftive natural areas where runoff is to be kept to a mintmum.

18. Polne source types of discharges shaII be prohtblted on steep embeniswents.

19. In "L" flood sones where substantel amounts of fill are required, particutaris around Iow-lylng portions of coastal pond areas, the we of eflt ahall be probiblted, and dvellings ahall be elevated $\because \cdot$ or pareltal conerete valls or on pifings or columns. 
20. All single-family building additions shall require an ISDS "change of use" permit.

21. AII new ISDS gyatems require ISDS permits. Applicant's are advised to meet on-site with GRMC staff polor to the commencement of ISDS groundwater tests, etc., to discuss Iocat1on, setbacks, etc. (This is offered in Ileu of a standard ISDS setback and density requirement which should be prepared for coastal areas, but appears to be constderably down the Iine.)

22. Exemotve filling in the Cosstal Flood Platn, when necessary and pacmitted, abil be reetricted to the nonpeak hurflcandiseason to minimize the probability of rashout.

23. The Conversion of dvellings from seasonal use to year-round use ahall require an ISDS upgrading, if necessary.

REREREACE: =eroston and sedimentation controls.

Eealdentlal Construction on a Barfier Beach.

I. Revegetation of the site shall occur in accordance with the staff recommendat1ons for vegetative tjpes and planting schedules (beach grase, pes, etc.)

z. Duffer zones shalf be extabltohed as a necesaury step to protect

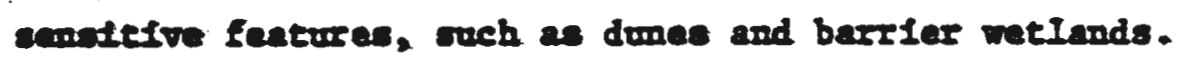

3. The drefitng shall be anchored to ptlings in accordance with the Bhode Ialand Seate BufIding Code for construction in Flood Bazard 
Areas, elevated 6 feet above the 100-year flood level established by the Flood Ingurance Rate Maps, and with p1lings driven deep enough to withstand scour.

4. A regtotered profesalonal englneer or archttect shaIl certfy that the structure is securely anchored to adequately anchored pilings or columb in order to fthstand veloctty and hurrlcane wave wash.

5. 411 debris and excess boflding matertals shall be properly disposed of at a aftable upland locatlon, not on the dure, the margh, or In the wetara of the state.

6. Constructon actifletes or alteratlons shall be conflned to that ares landward of the dune or dune remnant. The dune shall be staked out by the staff blologlat or the staff engtneer.

REFGRENGES: -Realdentlal Construct10n, General Conseruct10n, Accessory Structures.

- Erostor and sedimentation controls.

- Cencral Protection of Pbyslographical Peatures

\section{Comerctal ButIding Construction.}

I. The structure shalI be eleveted to or above the approprlate bage flood elevation or flood-proofed in accordance with the Shode IsInd sente BufIdtng Code for construction in Flood Bnsurd Areas (1xtiale 4. Section 300.23).

2. Local nonsupervised fIre alarw system shall be Installed where appro- priate. 
3. Monttoring or inspection of the integrity of burled fuel storage tanks shall be required.

RHFRENCB: -ResidenttaI Constuct10n, General Construct1on, Accessors Structures

- Erosion and sedimentation controls

\section{Dredging.}

1. Techniques utilized sball be to minimize turbidity and sedimentator.

2. To prevent the release of obsordous odors and mintmire impaces on infore organtent; dredglag shall preferably occur In cool months.

3. Sotl cover shall be used to cap the dredged materlal to prevent the release of obnoxdous odors, If necessary.

4. Denatering of dredged materlal shall occur behind a berm of affletent hetght to contain the materfal; bay bales shall bo staked around the outside perfmeter of the berm to capture gediment Iaden meter, if necessary.

5. Shellfish dredged frow watars clasalfied SB or lower shall not be made avaliable for cousumption or for balt.

6. AII dredged arene shall bave atton slope of 50 percent C. $\quad \therefore$ or Inse to atd in efrealation and fitibutng.

T: "Dredged metertal disposed of on stte shall be covered with - I to 5-foot clean earth cover. 
Plers, Docks, Floats

1. All pilings shall be securely driven into the subs trate.

2. The minimum spactng between decking shall be no less than onehalf inch to allow Ilght penetration to fringe marsh, and the minfum dock hefght shall be one to two feet above marsh vegetatiox.

3. All matertals, removed pilings, and excess debris shall be properIy dtsposed of at a suttable upland location, not in the waters of the state (or on the beach or on the marsh).

4. Dtscharge of wates from boats ustng this factlfty toto the waters of the state, shall be prohiblted.

5. No grading or filling activities along the shoreline shall occur Ithout the review of approval of the CRMC.

6. PIIfogs shall not be placed in the fringe marsh.

T. Pter decle shall mafntain clearance over mean blgh water to allow Iatearaf access. (In most cases, this clearance has beer stipulated at 5 or 6 feet).

8. The pter shall be abutted to the embanioment wlthout alteration of the embankment, or the embankment shall be properly cutback and stablitized, If necessary.

9. Stondart dock wideh shall be no greater than 4 feet.

10. Floats and ramps and other equipment shall not be stored on the marsh or embankments. 
Boat Launching Ramps.

1. All work on boat launching ramps shall be confined to the low tidal creIe.

2. AII excavated material shall be removed from the site.

3. The ramp shall be extended upland far enough to prevent wave rumup and washout at the inland edge.

4. Concrete raflroad tles or simflar concrete flextble base shall be used for boat ramps in Iow energy wave areas, placed on a gravel base to resist undercutting and cracking.

\section{Martna Factlities.}

1. Pumpout facilftes shall be installed as the need arises.

2. Sufflefent santtary facliftes shall be provided to service addttional martina users.

3. The dfscharge of wastes from boats using thls factilty into the vaters of the state be prohiblted, $\therefore$

REFEREMCE: -Plers, docks, flats, ramps -Dredging

-RIP rap and Other Shorellne Protection Baclities

Rip Rap and Other Shoreline Protection Factlitles.

1. The toe stone shall be placed in a toe trench at a depth equivitent of mean low water.

2. Vertical motared seavalls shall be generally prohtbited as they fncur damage from strong wave action. The use of Ilp rap type waIls stepped into the embankment shall be preferred technique if nonstructural techniques are not feasible. 
3. There shall be a unform grade and slope pitch controls not to exceed a maximum $40^{\circ}$ slope.

4. The staff biologist shallstake the warsh or the staff engineer shall stake the toe of the factilty prlor to the commencement of work.

5. Machinery shall not operate in the marsh.

6. Groins shail not be constructed of asphalt or soil; only concrete or rock material properly placed (not dumped) and angled in with the loagest axis parallel to the ground shall be ut1lized.

T. Gravel or crushed stone shall be placed behind the wall to stabllize the etructure and to serve as a filtering layer for sediments.

8. AII Ifp rap shall be placed, not dumped.

9. The ends of the rtp rap shall be tied in with the rematnder of the embankment or extsting walls.

10. FalI shall have drainage allowances.

11. Special engtreering or construction requirements shall occur in cases involving repatr of old and dflapidated stone piers, walls, ete.

Erosion and Sedimentation Controls.

(NOTE: The III the State of Rhode Island Erostor Control Handbook).

1. Dounspouts shall discharge undergramd: or onto splash pads to dffuse corizunafe.

2. The we of fitter cloth, jute macetng, fiber mesh feace or filter fabHe fence, crushed stone revetments, sedimentation barrlers, check dams, sod, seed berms, ditches, and swales shall be ut1IIzed where approprIate to control exoston. 
3. Low berns or curbs shall be appropriately placed to prevent erosion from runoff, especially on steep embankments.

4. Stairways to piers, from embankments, shall be elevated on small piles to prevent vegetative disturbance.

5. Dewatering discharges shall pass through hay bale and/or crushed stone sediment traps.

6. Dewatering wells used to lower water table during deep excavatons shall be driven polnts or drilled castag.

7. Dewatering discharges shall not be directed into storm dratns.

\section{Drainage. Factlities.}

I. Drains shall have three-foot sumps with permeable bottoms.

2. Grease traps and ofl separators shall be fnstalled as necessary.

3. Absorbant materfals shall be used to capture runoff bituminous Ifqueds durting paving operations.

4. Outfalis shall have splash pads of proper design size to prevent scour:

5. Screens or grates shall be placed over the outfalls to trap debris.

6. A matntenamce schedule shall be required for street cleaning and cleaning sumps and outfalls.

7. No tle-tns with butIdtngs or sewage systems shall be allowed.

8. InturaI strean bede and/or swales shall be utlitzed whenever pocelbie.

BETHRENCE: -RIp rap and Other Shoreline Protection Factifties. 
Aquaculture.

1. Assent shall be issued on an expertmental basis for three years.

2. Applicant shall file semlannual reports with the CRMC, provlding all data and information as required by the DEM Aquaculturlst.

3. Adequate markers delineating the site shall be installed and maintained.

4. Projects shall be for the cultivation of quahaugs, oysters, and missels exclusively.

5. Applfcant/owner shall be Ilable for clean up and restoration in the eveone of abandomment.

6. Owner shall notify the CRMC 30 days prlor to abandonment.

7. $\$ 20,000$ performance bond shall be posted.

8. No attempts to Implement predator control shall occur without Gric consent.

9. Profect shall be monftored by the DEM FIsh and WiIdIffe B1ologist (Aquacelturist).

NOTE: Aquaculture presently is not a routine use of coastal waters. Designation of aquaculture zones appears to be destrable and technfcally feastble.

Miscellaneous.

I. AII fIII, when utIIfzed, shall be properIF compacted and vegetated.

2. AIt seviage puming atations shall be flood-proofed beIow the base flood level (certifled by a registered professlonal engineer or arehltect).

3. AII subdratns shall be constructed of $6^{\prime \prime}$ pipe and the plpe traversing the borlzontal downslope Ieg shall be solfd, not perforated, 
and all joints shall be tight.

4. Access to the shoreline across sensitive features down steep embankments shall be managed by a stafrway, not a path.

5. AII fIII materfal shall be clean and free of matter that could cause poIIution of the waters of the state.

6. The rlght-of-way to the shore shall be kept free and clear of aII matertals and equipment used for construction of satd project.

Subdtvistons.

1. Subdivisfor lot sizes ir senstelve natural areas (Narrow River Water Shed, Coastal Ponds, particular coves) shall be of sufficlent size to allow low density development. (In accordance with the 208. Water Qualtty Management Plan, the minimum lot size in areas to be served by individual subsurface disposal systems and public waters should be at Ieast 15,000 square feet; 60,000 square feet in areas served by ISDS and private rells).

2. Cluster type development shaII be the preferred development techmique in all coastal areas. (Local communities should zone water front areas for large-lot or cluster-type developments to reduce runoff and related impacts on cosstal waters.)

3. Conseruction of storm vater runoff impoundment areas shall be favored as a means to reduce or prevent storm water runoff into coastal waters. (The 208 PIan recommends natural buffer strlps of 300 feet frow the raing season. flow Ine of a stream or the 
high water mark of a natural body of standing water in rurai areas, wherever possible.)

4. Conservation easements (or minimally buffer zones) shall be established upland from sensitive physiographical features.

5. Lots shall be combined, wherever possible, In sensitive natural areas to reduce densities and allow setbacks and buffer zones in accordance wth the standards contained herein.

6. Where a conflict arlses between protection of coastal physiographtcal features and waters in accordance with the standards contafned herein, and local requirements, applfcant's shall first seak reltef from locaI authortefes.

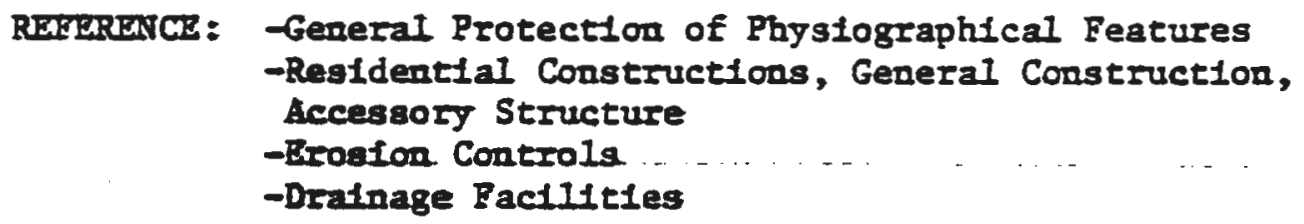

It Is recomended that tf these standards are amended to the RICRMP, they should simfIarly be amended to the applfcant's handbook, with tIIustrations. This is simflar to the "Developer's Handbook" approach utflized by other coastal states. 
- APPEIDIX II: TABULATED PROJECT DATA

BF COMUNITY, WATERBODF AND PROJECT TYPE 
TABLE II-1

PROJECTS BETORE CRMC BY COASTAL WATERBODT

\begin{tabular}{|c|c|c|c|}
\hline WATERBODY/COMMONITY. & $\begin{array}{l}1 / 01 / 75 \\
\text { thru (I) } \\
g / 30 / 79\end{array}$ & $\begin{array}{l}5 / 16 / 78 \\
\text { thru } \\
9 / 30 / 79\end{array}$ & $\begin{array}{l}11 / 19 / 79 \\
\operatorname{thru} \\
12 / 31 / 80 \\
\text { (2) }\end{array}$ \\
\hline
\end{tabular}

I. RARRAGANSEII BAT REGION/DRADIAGE

BASIN:

Acaderiy Cove, N. RIngatown

1

$I$

AIIen Barbor, N. Kengatown

$-$

2.

Apponas Cove, Warwick

$\mathbf{2}$

$I$

torsefingtor R1ver, Berringtor.

I6.

15

Bfaed Cove, M. Kingatowr

I

1.

2

BIue BIII Cove, Portsmouth

2

I

Breneor Cove, Newport

2

2.

4

2

2

BuIlocie Cove, Ease Prov1deace/ Barrington

9

$-$

5

Cold Spring Cove, N.K.

I

Duck Cove, LEtogstown

$-$

Dutely Cove, N. Ringatowr.

$I$

Dutch Barbor, Jameatown

$-$

$-$

1

Enet Paseage

If

14

9

Fintint Cove, I. KIngetow

2

1

3

Greanteh Bay, Marulde

4

3

4

Gremulch Cove, Bast Greenuleh

7

2

2

Gent Greek, Jamatows

I 
TATERBODI/COMMUNITI

$1 / 0 I / 75$

thru (I)

9/30/79
$5 / 16 / 78$

thra (1)

$9 / 30 / 79$
$11 / 19 / 79$

thru

$12 / 31 / 80$

I. NARRAGANSEIT BAT REGION/ DRADRAGE BASIN:

*Hundred Acre Cove, Barrington

Kfekemult RIVer, Brfstol

AnckeraI Cove, Jamectown

veII Cove, M. Kengatown

MiII Creek, N. Ringstown

Mt. Bope Bay, Bristol/

Portsmouth

6

larragansett Bay (General)

52

Hewport Barbor, Newport

13

Hortb Cove, N. Ringatorm

Oceupasturcet Cove, Rarwlek

*almer Rfver, Barrington

$\because$

Farturet Cove, Cranstou/

Wesulck

Pawturet Rfver, Cranstor

$I$

I

1

1

2

2

9

Pettaquamscutt RIVer, Rarraganete/SR/ML

14

4

9

$I$

5

4

1

6

5

4

1

$\because$ Potowonet Rivar, Narulek

Providence River, Prool

Dar./Craneton/EP/

Baselngtors

18

6.

3

Sakomet Rfver

29

9

II

Seakonk River

3

1

I

I

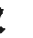

3

5




\section{TABLE II-1 (con't)}

WATER

WATERBODY/COMMNIIY

Sheffleld Cove, N- RIngstowr

Simfth's Cove, Barringtorx

Thateir Cove, Warwick

Tibbetts Creek, N. Ringstown

Warren River, Warrem

Taridele Cove, Farwtele

Went Pasage

Batchemoket Cove

Hickford Cove, N- Ringstowr

Wickford Barbor, $\mathrm{NR}$

Woonasquntucket RIver

SUBIOTAL:

PERAEII OF TOTAL:
$1 / 01 / 75$

thru (1)

9/30/79

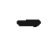

3

$-$

\section{-}

5

12

10.

-

3

7

2

268

.5929
$5 / 16 / 78$

thru (1)

$9 / 30 / 79$

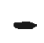

2

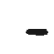

$I$

1

9

6

16

$I$

6

$I$

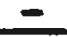

88

190

.5866

$.562 I$ 
WATERBOODY/COMMONITY

II. COASTAL PORDS:

*atry Pond, Nerpore

*hCormorant Cove, New Shoreham

*Easton Pond, Newport

Aaltlee B1rd Sanctuars

Pt. Iudith Pond, Nazragansett

*wGreat Salt Pond, Nen Shorehar

thGreen B1II Pond, ST

tEarbor Pond, New Shoreham

- Lake Canochet, Narragansett

titetle Pond, Narragansett

* Nev Harbor, New Shoreham

thinforet Pond

Aottex Pond, SK

tript. Judtth Pond, Bars./SK

tutcleand Pond, Itte Ie Compton

nuwochontang Breachway

waonochontang Pond

Seugatucket RfVer, SK

Hrin Pond, New Shorehom

inicalerperg Breschwey

* ifimapare Pood

Heaquage Pond, Narragansete

Mase Pond, Chnriestown
$1 / 01 / 75$

thru (1)

9/30/79
$5 / 16 / 78$

thru (1)

9/30/79
$11 / 19 / 79$

thru (2)

$12 / 31 / 80$
$(2$ 
TABIE II-I (Cont)

\begin{tabular}{|c|c|c|c|}
\hline WATERBODY / COMMUN ITY & $\begin{array}{l}1 / 01 / 75 \\
\text { thru (1) } \\
9 / 30 / 79\end{array}$ & $\begin{array}{l}5 / 16 / 78 \\
\text { thru (1) } \\
g / 30 / 79\end{array}$ & $\begin{array}{l}11 / 19 / 79 \\
\text { thru (2) } \\
12 / 31 / 80\end{array}$ \\
\hline WATERBODY/COMMON IIYY & $9 / 30 / 79$ & $9 / 30 / 79$ & $12 / 31 / 80$ \\
\hline
\end{tabular}

Jnoramed Pond, Newport

$\begin{array}{lcc}= & - & 1 \\ 101 & 27 & 107 \\ .2234 & .1800 & .3165\end{array}$


TABLE II-1 (Con't

\begin{tabular}{|c|c|c|c|}
\hline & $\begin{array}{l}1 / 05 / 75 \\
\text { thru (1) }\end{array}$ & $\begin{array}{l}5 / 16 / 78 \\
\text { thru (1) } \\
0 / 3 n / 70\end{array}$ & $\begin{array}{l}11 / 19 / 79 \\
\text { thrs }(2)\end{array}$ \\
\hline WATERBODY / COMLYUNIIIY & $9 / 30 / 79$ & $9 / 30 / 79$ & $12 / 31 / 80$ \\
\hline
\end{tabular}

III. COASTAT DRATRAGZ BASIIS/SOUNDS:

Block Island Soumd

36

3

22

Col. Willie Cove, Westeriy

$\begin{array}{lll}- & - & I \\ - & - & I \\ - & - & 2 \\ 2 & 1 & - \\ 2 & - & \end{array}$

Pawcatuck RIVer, Testerly

1 I.

7

10

Bhode Island Sound.

32

24

$\underline{5}$

SUBTOTAR:

83

35

41

PERCENI OF TOTAL: $\quad .1836$

.3333

.1213

rorat:

$\underline{\underline{452}}$

$\underline{150}$

338

1101us: (I) Whiteaker and Amato, pp. 144-145. Orfgloal Source was the Difision of Coastal Resources "assent f1le" which had a 40 percent lag behtod the total numbered applicathone for the perlod. Menor counting difference of approxdmately I percent exist between totals presented here and those reported by Whttaker and Amato.

(2) Divlaton of Coastal Resources "CRMC Assent Log" ma1nenined by the DIflaton's Planner. Data includes all applications put out to notice for perfod studied.

PCMR Area for Preservation and Restoration, Low Intensity/Conservation Use, Type I Eatunry.

- EICDup Area for Preservation and Restoration, multiple we recreation, Type 2 Batury.

A-Area for Preservat1on and Restorat1on other than Batuary tgpe, such as sea ciffes and large salt marshes. 
TABLE II-2

TABULATED FINDINGS FOR PROJECI LOCATIONS

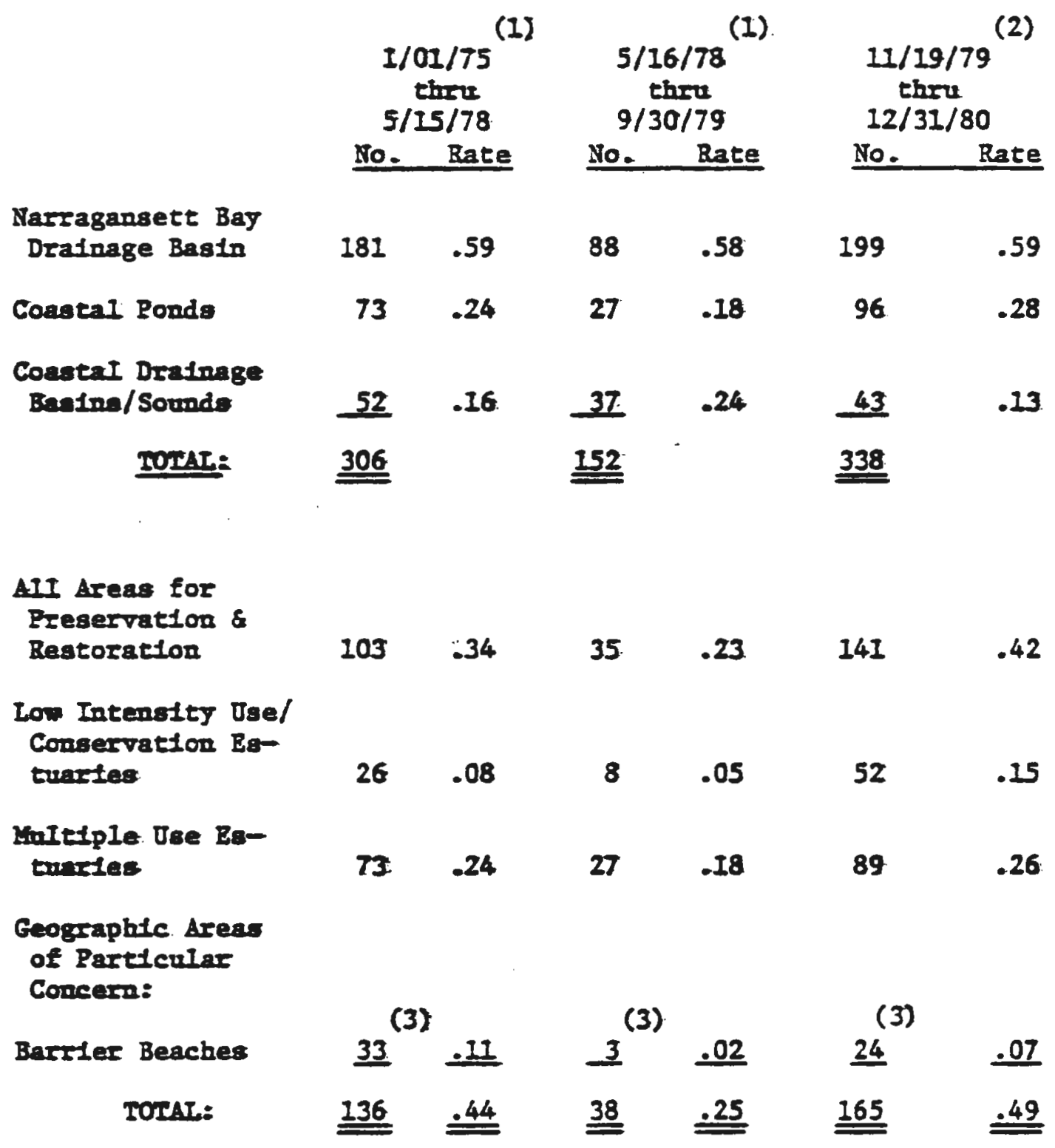




\section{TABLE II-2}

NOTES

(I) As measured by assents contalned in the Rhode Island Department of Bnviromental Management, Division of Coastal Resources, "Assent Bile, reported by Amato and Whitaker in Coastal Society ProceedIngs, November 6-8, 1979, pp. 145-156. It is noteworthy that they found 40 to 50 percent fewer agsents recorded than actual appllcatlons processed and concluded that this was prtmarily due to clerical errors and the general lag in the dectslon-maktng process. The Division's January, 1981, Staff Report to the CRMC reveals an average backlog for 1980 of 130 cases.

(2) Tabulated fron the Diviston of Coastal Resources Log of CBMC Permits natintaned by the Staff Plamer.

(3) Wore accurateIy, this figure represents profect assents reported for Block Ialand Sound which is predominately in a Barrier Beach status and is entirely in a "p" high-harard flood zone. Thls flgure does not reflect the 32 project permtts along Rhode Island Sound whtch is also entirely a "V" hlgh-hazard flood zone, but is less domtoated by barrler beach features. 


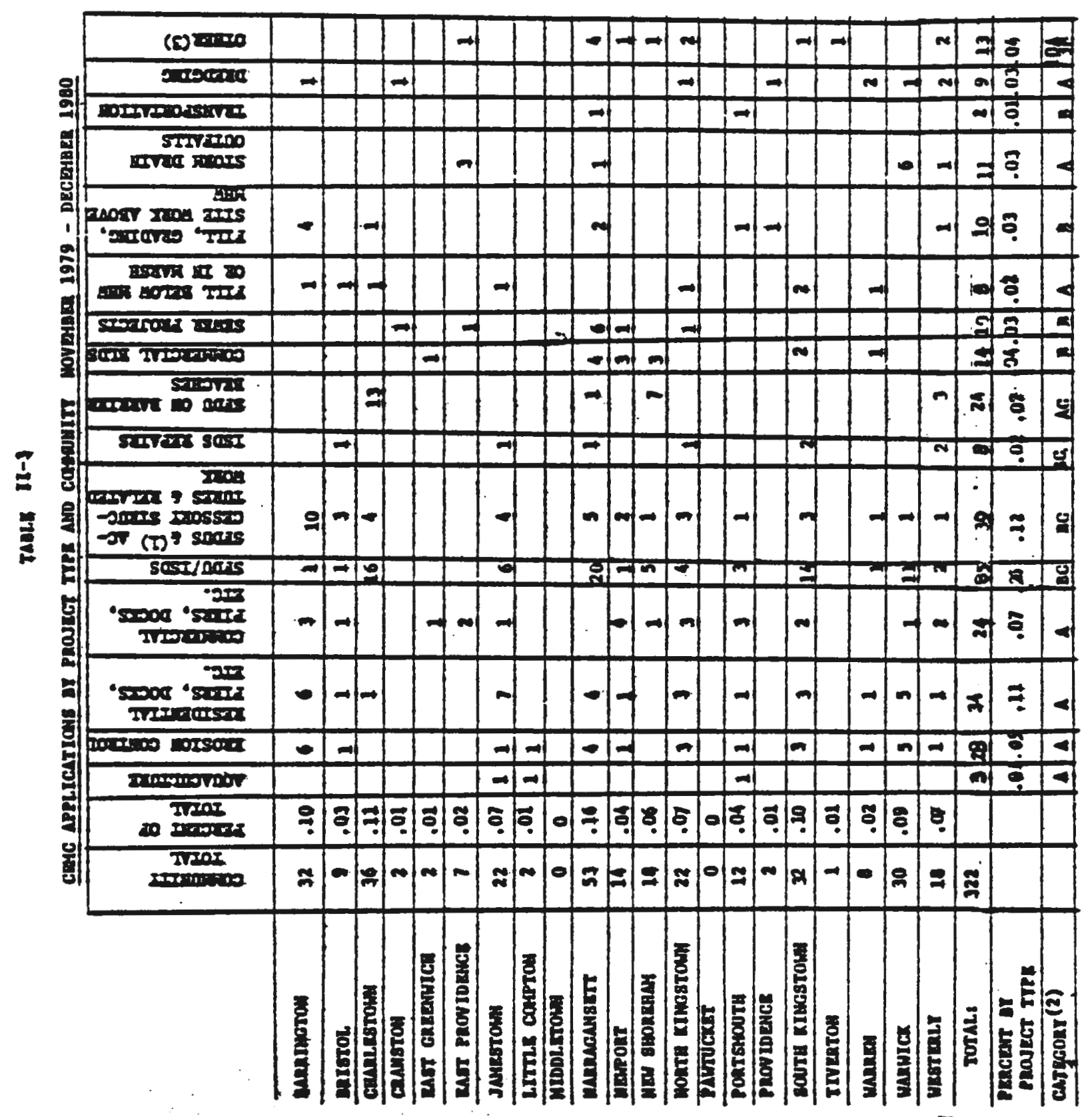


NOTES TO TABLE II-3

"CRMC Application by Project Type and Community, November 1979 December 1980."

I. SEDd's reflected in this category can be for new dellings tied Into Iocal communty sewer systems, as well as for dwelling repalrs, and addtttons, etc.

2. Categorfes showr are as follows: (a) Area of primary furtsdietion as reflected by 197 statute resulted in 47 percent of the Application case Ioad; (b) Area where primary governmental furtsdiction is clearly local, not state, resulted in 53 percent of the case Ioad; sewers are in thls category because CRMC reVlews are at the project level and examine only stte impacts; (c) reflects all single-family dwellings related activities and these constitute 48 percent of all the case load; the. large majorfte of which pismaify fall into local furlsdiction (BC); and (AC) reflects single-family drelling activities on barrler beaches, an area of primary CRMC furfsdiction, representing approxtmateIy 16 percent of all activities occurring within the primary furlsdiction category.

3. These are: I chemical discharge into Seekont River, Rast Provldence: 2 private property atgma on a barfler beech in Narragansett; I sull wind-powered electrical generator; I power Ifne matrtenamce, I local Elght-of-way rehabilitation; I cooling pond for the Block Island Forrer Company; 2 mosqutto ditching profects in North Kingstown; I request to legalize asphalt paving on a dune; 
$\operatorname{sens} I I-$

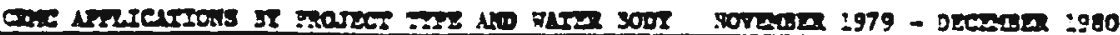

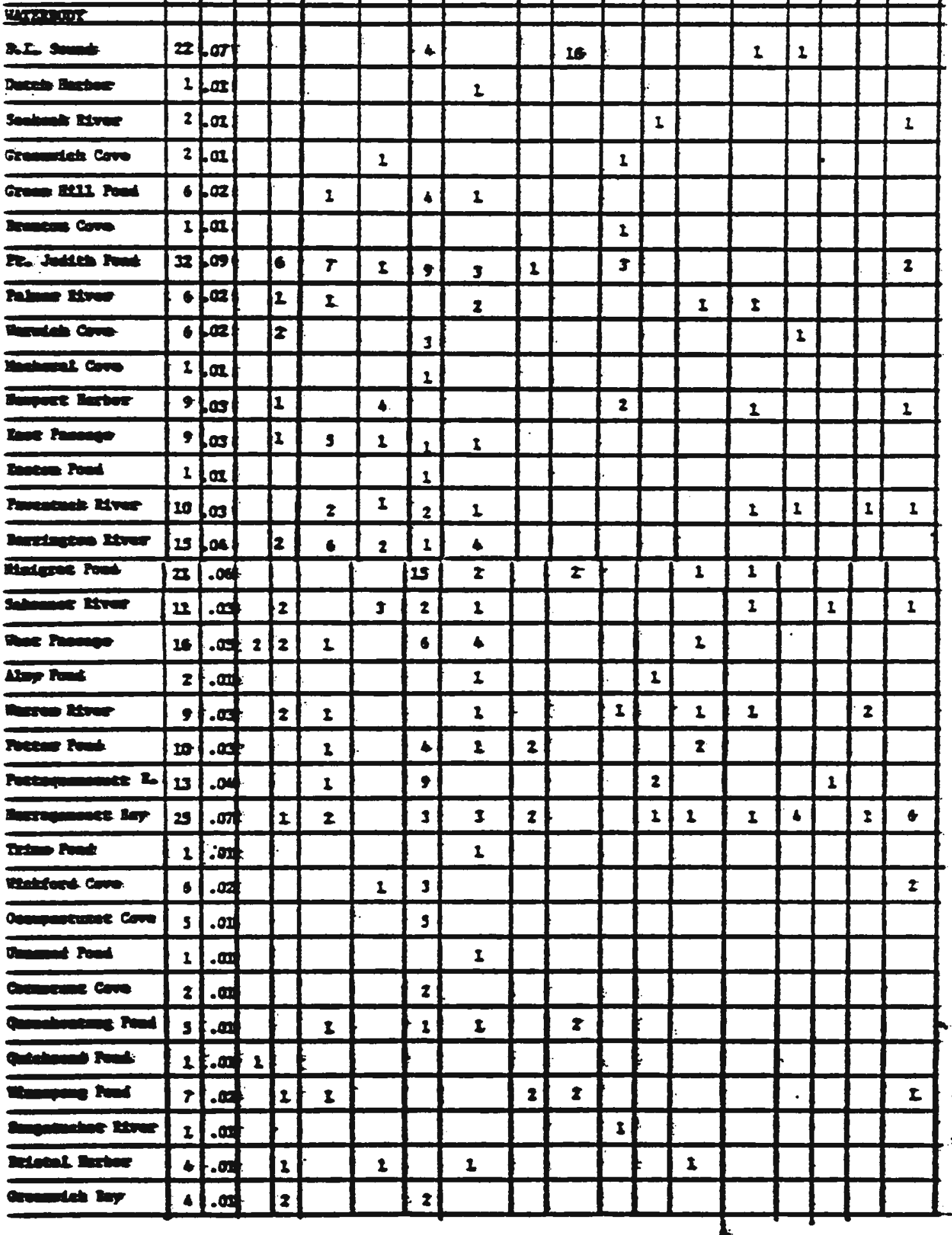

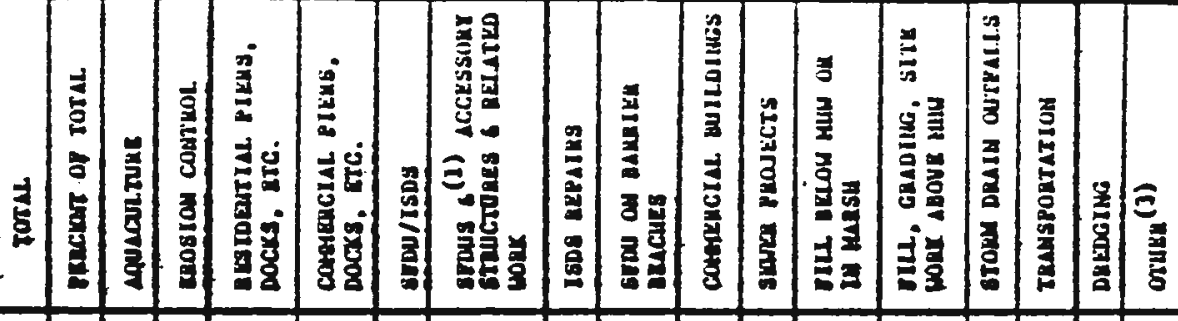




\begin{tabular}{|c|c|c|c|c|c|c|c|c|c|c|c|c|c|c|c|c|c|c|c|c|c|c|c|c|c|c|c|c|c|c|c|c|}
\hline & 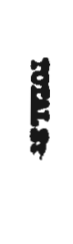 & & & & $\begin{array}{l}5 \\
t \\
t \\
t\end{array}$ & & f & $\left|\begin{array}{l}5 \\
1 \\
2 \\
5 \\
5\end{array}\right|$ & $\left|\begin{array}{l}0 \\
0 \\
0 \\
0 \\
0 \\
0\end{array}\right|$ & & 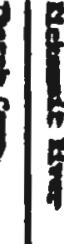 & $\mid \begin{array}{l}1 \\
\boldsymbol{i}\end{array}$ & $\mid \begin{array}{l}5 \\
7 \\
7\end{array}$ & & 影 & 5 & $\begin{array}{l}\mathbf{5} \\
8 \\
8 \\
8 \\
8\end{array}$ & & 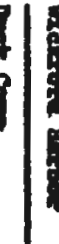 & 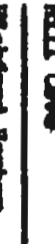 & $\left|\begin{array}{l}E \\
8 \\
8\end{array}\right|$ & $\left|\begin{array}{c}5 \\
8 \\
7 \\
7\end{array}\right|$ & 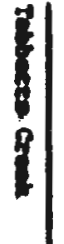 & 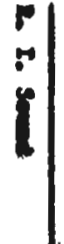 & 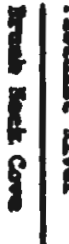 & & 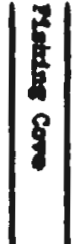 & $\begin{array}{l}5 \\
7 \\
7\end{array}$ & & $\mid \begin{array}{l}\beta \\
8\end{array}$ & 8 & \\
\hline & $\overline{8}$ & -1 & H. & $=$ & $m$ & Io & 10 & $\omega$ & $\sim$ & $\theta$ & 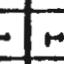 & $\omega$ & $\omega$ & - & $\omega$ & $\omega$ & $n$ & F: & 5 & If & $N$ & $\approx$ & -1 & 4 & $\triangle 1$ & to & $\infty$ & 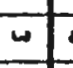 & - & I & $E$ & toorsL \\
\hline & & $\dot{\mathrm{g}}$ & $\dot{\mathbf{g}} \mathbf{i}$ & $\dot{s}$ & $\dot{8}$ & 定 & $\dot{\varepsilon}$ & $\dot{\mathbf{g}}$ & $\dot{\mathrm{g}}$ & $\dot{8}:$ & $\dot{i}$ & $\dot{s}$ & $\dot{q}$ & $\dot{8}$ & $\dot{\theta}$ & $\dot{\boldsymbol{\beta}}$ & $\dot{\beta}$ & $\dot{\varepsilon} \dot{\varepsilon}$ & 9 & $\dot{5}$ & $\dot{\varepsilon}$ & $\dot{s}$ & $\dot{9}$ & $\dot{s}$ & 8 & $\dot{8}$ & $\dot{8}$ & i & $\dot{8} \mid \dot{E}$ & $\dot{E}$ & $\dot{0}$ & PLRceat or total \\
\hline$\dot{g}$ & $\omega$ & & & & & & & & & & & & & & & & & & & & & 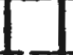 & & 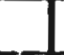 & 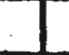 & $L$ & $\square$ & $\therefore$ & . & I: & T & \begin{tabular}{|l|l|l} 
LRUACULTUAR \\
\end{tabular} \\
\hline 8 & $\$$ & & & & & & [- & & & & & & & n & & & 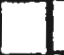 & & & 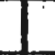 & 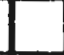 & [ & & $\omega$ & & L & $\because$ & 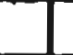 & 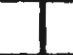 & T & T & ELOS STOA CONTROLL \\
\hline$\dot{3}$ & 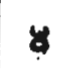 & & & & & & & & & & & & & & & & & & & & & & & & & & & & & & & $\begin{array}{l}\text { aksiLestial PIERs } \\
\text { Docks, ETC. }\end{array}$ \\
\hline 9 & $*$ & & & & & & & & & & & & & & o & & $\omega$ & & & & & or & & 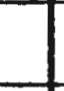 & & r & N & & & 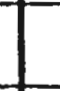 & r & 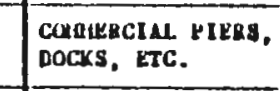 \\
\hline 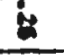 & 9 & & & & & & & & 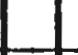 & L & & & $\infty$ & 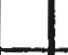 & & $\omega$ & & 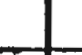 & 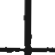 & 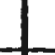 & & 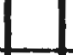 & & -1 & $\omega$ & & & 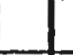 & 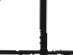 & H & & stou/rsas \\
\hline E & $y$ & & & & & & & & $\omega$ & & o. & & $\infty$ & $\omega$ & & & & or & & & & & & m & & & & $r$ & r. & & & 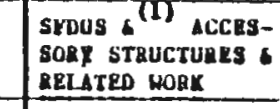 \\
\hline 8 & $\cdots$ & & & & & & & & & & & & & & & & & {[} & & 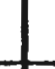 & & & & L & & & & 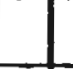 & & & & IsDS MEPA ARs \\
\hline$\dot{9}$ & $\approx$ & & & & & m & & & & & & o & & & & & & & & & & & & 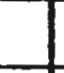 & & & & 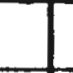 & & & & 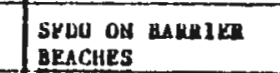 \\
\hline 8 & $E$ & $\omega$ & & & & & & & & & & & & & & & & & & & & & & - & & & & & & & & 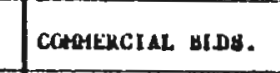 \\
\hline 8 & $E$ & & & & 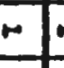 & - & & & & & & & & & & & & & & & & & & 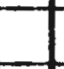 & E & & & $L$ & - & & & $\begin{array}{l}\text { stuKM PRojects } \\
\end{array}$ \\
\hline$\dot{\varepsilon}$ & - & & & & & & & & & & & & & & & & & & & & & & & 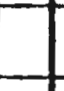 & & & & & & & & 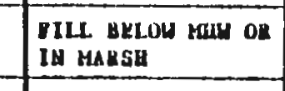 \\
\hline$\dot{q}$ & E & & & & & & & & & & & & & & & & & & & & & & & $\omega$ & & & & r & & & & 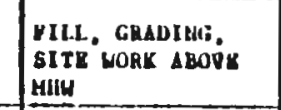 \\
\hline$\dot{a}$ & E & & & & & & & & & $\boldsymbol{r}$ & & & & & & & $\sim$ & & & & & & & & & & & & 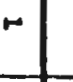 & & & 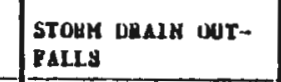 \\
\hline$\dot{g}$ & $\sim$ & & & & & & & & & & & & & & & & & 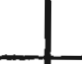 & & & & & & & & & & & & & & Tuansfout tatiou \\
\hline 8 & $\infty$ & & L & 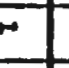 & & & & & & & & & & & & & & 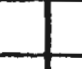 & 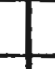 & 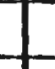 & 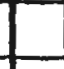 & . & & & & & & -1 & $N$ & & & 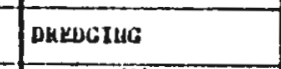 \\
\hline 8 & 8 & -1 & 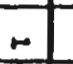 & & & & & $\infty$ & & & & & & & & & & N & I. & - & In & $\omega$ & - & & & & $\omega$ & & & & & отиes (3) \\
\hline
\end{tabular}

